\title{
POLITICAL MARKETING AND THE BRITISH LABOUR PARTY 1994-2010: APPLYING THE PRODUCT LIFE-CYCLE MODEL TO A POLITICAL PARTY
}

\section{BRETT RAYMOND DE MALMANCHE}

A thesis submitted in fulfilment of the requirements for the degree of Masters of Arts in Political Science at Victoria University of Wellington 


\section{Abstract}

This thesis explores the merits of applying a marketing model, the product lifecycle model, to a political party. The product life-cycle model details a product during its introduction, growth, maturity and decline cycles. For this thesis I apply this model to the British Labour Party between 1994 and 2010 under the leadership of Tony Blair and Gordon Brown. The product life-cycle model, adapted to political science from the political marketing literature, shows that a political party does go through an introduction, growth, maturity and decline phase. To avoid moving into the decline phase, a political party must learn how to rejuvenate during the maturity cycle. This thesis concludes that the product life-cycle model does have merits when applied to political parties. In the case of the British Labour Party, it began with a strong market-orientation, but the longer it stayed in power this market-orientation shifted. The New Labour brand and its primary brand agent, Tony Blair, were both strong assets to the party. However, during the lifetime of the product these assets became liabilities. The longer that New Labour stayed in power, the more it shifted away from its relationship with the political market. The product life-cycle model should be tested in other political systems to further strengthen its explanatory power. 


\section{Acknowledgement}

This is my second attempt at writing a thesis on political marketing, this thesis has taken on a different form to the thesis I first had in mind in 2003 when I first proposed the topic. I would like to thank my supervisor Dr Jon Johansson for all his help and patience with me during my first attempt and helping me across the finishing line this time around. I would also like to thank Professor Claire Robinson, our conversations at the beginning of my research helped me to form my ideas and directed me towards the right literature. I would also like to thank Associate Professor Jennifer Lees-Marshment who kindly came and talked to me about my ideas at Auckland Airport in 2007.

I would also like to thank Adrian Durham for helping me cross the finishing line and his support, especially in the last year. Likewise, I also like to thank my family and friends for their support during this long and drawn out process, especially to my late-grandfather, Ray de Malmanche, who came from a generation and family that never attended university, he would have been proud that I have finally completed this massive project. Friends who deserve a special mention are Emily Dickie, Gemma Chmielewski and Anthony Santella.

Finally, below is the famous 'man in the arena' quote by Theodore Roosevelt which stated that:

It is not the critic who counts; not the man who points out how the strong man stumbles, or where the doer of deeds could have done them better. The credit belongs to the man who is actually in the arena, whose face is marred by dust and sweat and blood; who strives valiantly; who errs, who comes short again and again, because there is no effort without error and shortcoming; but who does actually strive to do the deeds; who knows great enthusiasms, the great devotions; who spends himself in a worthy cause; who at 
the best knows in the end the triumph of high achievement, and who at the worst, if he fails, at least fails while daring greatly, so that his place shall never be with those cold and timid souls who neither know victory nor defeat. ${ }^{1}$

I have dared greatly and have gone into the arena to produce this thesis. I have made mistakes along the way, I had moments of great enthusiasm and inspiration where everything just flowed from me and I had days where I could not face writing and I wanted to stay in bed. And my primary critic was me. But with the help and support of friends and family and determination I have managed to push through and complete this beast.

\footnotetext{
${ }^{1}$ Theodore Roosevelt, 'The Man in the Arena,' Accessed 1 May 2014 <www.theodore-roosevelt.com/trsorbonnespeech.html>
} 


\section{Table of Contents}

Abstract iii

Acknowledgements iv

Lists of Tables and Figures ix

$\begin{array}{ll}\text { Introduction } & 1\end{array}$

$\begin{array}{ll}\text { 1. Political Marketing } & 7\end{array}$

1.1 What is Political Marketing 7

1.2 Why has Political Marketing 9 emerged

1.3 The Evolution of Political Marketing 14 as an Academic Discipline

1.4 Criticisms of Political Marketing 16

2. The Product Life-Cycle Model 25

2.1 The Product Life-Cycle Model 26

2.2 Comprehensive Political Marketing 29

2.3 Market Positioning 34

$\begin{array}{lll}2.4 & \text { Branding } & 37\end{array}$

2.5 A Product Life-Cycle Approach to 50 Politics

3. Failed Labour Products (1979-1994) 55

3.1 Labour under Michael Foot 56

3.2 Labour under Neil Kinnock 61

3.3 Labour under John Smith 67 
4.1 Democrats Influence on New Labour $\quad 70$

$\begin{array}{lll}4.2 & \text { Product } & 72\end{array}$

$\begin{array}{lll}4.3 & \text { Positioning } & 76\end{array}$

4.4 Brand Narrative 82

4.5 Brand Agent 89

$\begin{array}{lll}4.6 & \text { Summary } & 91\end{array}$

5. Growth 93

5.1 Product 94

$\begin{array}{lll}5.2 & \text { Positioning } & 107\end{array}$

$\begin{array}{lll}5.3 & \text { Brand Narrative } & 111\end{array}$

$\begin{array}{lll}5.4 & \text { Brand Agent } & 114\end{array}$

$\begin{array}{lll}5.5 & \text { Summary } & 116\end{array}$

$\begin{array}{ll}\text { 6. Maturity } & 119\end{array}$

$\begin{array}{lll}6.1 & \text { Product } & 120\end{array}$

$\begin{array}{lll}6.2 & \text { Positioning } & 132\end{array}$

$\begin{array}{lll}6.3 & \text { Brand Narrative } & 135\end{array}$

6.4 Brand Agent 141

6.5 Summary 144 
7. Decline 145

7.1 From Maturity to Decline 146

$\begin{array}{lll}7.2 & \text { Product } & 149\end{array}$

$\begin{array}{lll}7.3 & \text { Positioning } & 155\end{array}$

$\begin{array}{lll}7.4 & \text { Brand Narrative } & 158\end{array}$

7.5 Brand Agent 161

$\begin{array}{lll}7.6 & \text { Summary } & 163\end{array}$

$\begin{array}{ll}\text { Conclusion } & 165\end{array}$

$\begin{array}{ll}\text { Bibliography } & 169\end{array}$ 


\section{List of Table and Figures}

$2.1 \quad$ The Product Life-Cycle 27

$\begin{array}{lll}2.2 & \text { Brand Strategies } & 42\end{array}$

$2.3 \quad$ Brand Narratives 49

$2.4 \quad$ Adapted Life-Cycle Model 52

2.5 Adapted Produce Life-Cycle 53

4.1 Satisfaction of John Major's Conservative 78

Government 1992-1997

4.2 Tony Blair's Satisfaction as Opposition Leader 89 1994-1997

4.3 ICM Polling Data 1992-1997 90

5.1 Satisfaction of Blair vs. Labour $\quad 116$

6.1 Labour MP Rebellions 123

6.2 Approval and Disapproval for the Iraq War 130

6.3 Satisfaction for Blair and the Government 142-143 2006- June 2007

7.1 Issue Salience Leading up to the 2010 General 156 -157 Election

7.2 Issues Identification by Party (2010) 



\section{Introduction}

At a basic level political marketing is about putting the political consumer, or voter, at the centre of the political process. Political products, such as political parties or candidates, that, in theory, best reflects the views of the political consumer succeed at elections and remain in government compared to those who do not. This thesis examines how the relationship between the political consumer and a political product develops and changes over the life of a government.

Generally when a political product enters office it is greeted with cheers and celebrations and when it loses power it sneaks out the back door. Why does the relationship that a political product built up with the political consumer go sour in the end? Do political consumers and political products simply fall out of love with each other? Is there a design flaw with the political products? Or do political products get distracted by the responsibility of government and forget their primary relationship with the political consumer?

The political marketing literature focuses on how political marketing is used to get a political product elected. While this is an important part of political marketing, this study is also just as interested in the maturity and decline of a political product. Can political marketing offer an insight for political products to extend their life and time in office?

For this study I adapt the product life-cycle model, which is a marketing model, and apply it to the British Labour Party. The aim of merging a marketing model to a political organisation is to gain a different understanding of how New Labour gained support and won government in 1997; how it built and maintained support and, then; how it lost its support, leading to its decline and eventual defeat in 2010. Looking at the New Labour case study using this model may give political scientists a different perspective of what was right and what went wrong with New Labour. 
In adapting the product life-cycle model to politics this thesis covers the creation of New Labour, its growth into a governing party, its maturity as a party that was in office long term, and its decline as it lost support in its later office. This thesis aims to:

- Make a contribution to political marketing literature which, as far as my research shows, has not examined the product life-cycle in much detail. ${ }^{2}$

- Examine and evaluate if an adapted version of the product life-cycle model can be applied to political parties.

- Ask if an adapted version of the product life-cycle can reveal something new about political parties.

\section{Why New Labour?}

New Labour has been a popular case study for political marketing studies. As Lees-Marshment has noted, this is because of a large concentration of political scientists, interested in political marketing, in the United Kingdom. ${ }^{3}$ New Labour is an ideal case study for applying a product life-cycle model to a party. Visually it is easy to see the contrasting images of a fresh-faced Tony Blair arriving at Number 10 Downing Street in 1997 and the drained and older looking Blair leaving in 2007. New Labour hung on with its new leader, Gordon Brown, for three more years until it was ousted from office in 2010.

The main reason why I chose New Labour as my case study is simply because it is a topic that interests me. I was 17 when Blair was elected in 1997 and I remember vividly watching the campaign on Sky TV with great interest, despite being in New Zealand. As an undergraduate student I researched and wrote about New Labour at any given opportunity. I wrote essays, from an analysis of the third way as a political movement, to comparing New Labour's first term in government with Lionel Jospin's Socialist Government in France. In 2010 I lived

\footnotetext{
${ }^{2}$ Jennifer Lees-Marshment (2009), Political Marketing: Principles and Applications, Routledge, Oxon, pp. 110111, briefly covers the Product Life-Cycle Model in her book and suggests that the model could be applied to politics.

${ }^{3}$ Lees-Marshment (2009), p.2
} 
in London and worked for the Department of Health in Whitehall (across the road from Downing Street) during the general election campaign. I fanatically followed the election, from the three televised debates to the Browns leaving Number 10 at dusk before David Cameron's arrival hours later.

The other main advantage of using New Labour as a case study is that there is plenty of information on the topic. At the time of writing this thesis many key players in New Labour have published their autobiographies, including Tony Blair and Peter Mandelson. Philip Gould, before his death in 2011, updated his 1998 book The Unfinished Revolution, which includes a strategic analysis of New Labour in government. Political scientists and journalists alike, notable Andrew Rawnsley, have also published their works and analysis on New Labour in government.

\section{Structure of the thesis}

Chapter one of this thesis is an introduction to political marketing. I examine current definitions of political marketing and discuss what political marketing is. Then I outline why political marketing has emerged and review current political marketing literature.

Chapter two discusses, in detail, the models that is used in this thesis and applied to the case study. The main models used are:

- The product life-cycle model which is a marketing model and is the basis of this thesis. This model looks at the life of a product during its life-cycles. It has five cycles: 'product development', 'introduction', 'growth', 'maturity' and decline.

- Comprehensive political marketing model (CPM) which was developed by Jennifer Lees-Marshment, and which argued that political parties and candidates can have three types of orientations, 'product', 'sales' and 'market'.

- The market positioning model developed by Neil Collins and Patrick Butler, which argued that a party has different competitive strategies 
dependant on the position they are in; there are four positions: 'market leader', 'challenger', 'follower' and 'nicher'.

- Brand narrative and brand agent models developed by Laurence Vincent.

Chapter three is a backgrounder to the New Labour case study. To understand why the New Labour product developed the way it did it is important to take a look back at the failed Labour products that preceded New Labour. Before Tony Blair came to office the Labour Party had experienced 18 years in opposition and had lost four elections. Through the 1980s the party was divided and was plagued by division and infighting.

Chapter four looks at the 'product development' and 'reintroduction' part of the product life-cycle model. Looking at the product created by the New Labour founders in 1994 and how it was introduced to the political market as an opposition party and how they gained momentum and support to move to the next cycle.

Chapter five examines New Labour during the 'growth' part of the product lifecycle model. This is New Labour's transition from the opposition to government and its early years in office, around 1997 until 2001, its years of political ascendency.

Chapter six examines New Labour during the 'maturity' part of the product lifecycle. In this period the New Labour product had been around for some time. Support for the party had peaked and was starting to decline. This chapter provides evidence that New Labour attempted to reinvent itself during this part of the cycle. Can the New Labour experience offer lessons to other political parties in the maturity cycle. During this part of the cycle Blair faced much controversy during and after the Iraq war. To renew New Labour the party also changed leaders from Blair to Gordon Brown. 
Chapter seven outlines New Labour during the 'decline' cycle. At this point Labour moved away from the 'New Labour' model under the leadership of Brown. It eventually moved back into opposition.

I conclude this thesis by discussing whether or not the product life-cycle model can be appropriately transferred to political parties. If so, what lessons can it offer political parties and how can this research add to current political marketing thought. 


\section{Political Marketing}

Political marketing is a topic that generates much controversy amongst people. When telling people that I am writing a thesis on political marketing I would often receive lectures on how political marketing has destroyed politics and that politics is more about spin and style over substance. However, political marketing is much broader than communications, which is the common misconception. This chapter outlines definitions and concepts of political marketing. The chapter is divided into four parts:

- What is political marketing? I examine current definitions of political marketing.

- Why has political marketing emerged? This section looks at what social changes have made political marketing more prominent.

- The development of political marketing as an academic discipline. This section looks at how political marketing emerged as an area of research and look at how the research has been developed.

- Criticisms of political marketing. Finally this section examines the common criticisms made about political marketing.

\subsection{What is Political Marketing?}

Political marketing is a new discipline that has emerged from the joining of political science and marketing. Since the field is still in its infancy academics are trying to establish research areas in the subject. Political scientists and marketers alike have different perspectives and tend to focus on different aspects in political marketing. The American Marketing Association defines marketing as, 'the process of planning and executing the conception, pricing, promotion and distribution of ideas, goods and services to create exchanges that satisfy individual and organisational objectives.' ${ }^{4}$.

\footnotetext{
${ }^{4}$ Quoted from Margaret Scammell (1999), 'Political Marketing: Lessons for Political Science,' Political Studies, vol.47, p.725
} 
Currently there is no uniform definition of political marketing. Lees-Marshment stated that, "political marketing is about political parties adapting business concepts and techniques to help them achieve their goals.'5 Scammell observed that since the research area is so new there are many different labels for political marketing, rightly or wrongly. It has also been called 'political management', 'packaged politics', 'promotional politics' or more broadly 'modern political communications.' ${ }^{\prime}$

The central focus of any political marketing definition should focus on the marketing concept. The marketing concept stresses a consumer-oriented approach to marketing where 'the customer [is] at the beginning rather than the end of the production-consumption cycle.'7 In political terms, appealing to the voter should begin at the start of the political process rather than later on. For example, a political party, when developing its policies should be considering the views of the voter at the very beginning rather than creating a policy programme and then asking the voters for its approval at an election.

Scammell stated that the 'marketing concept' is the key to understanding political marketing; 'Without it, we are still talking about essentially a modern form of propaganda [when relating political communications to politics]. With it, we are dealing with a transformation of political organizations and fundamental relationships between leaders, parties, members and voters.'8 Political marketing is about placing the voter at the beginning of the political cycle, using marketing tools to determine the needs and expectations of the voter, and attempting to deliver these goals. Other aspects of political marketing such as political communications and management, even though they are valid, are subsets of political marketing.

\footnotetext{
5 Jennifer Lees-Marshment (2001a), Political Marketing and British Political Parties: The party's just begun, Manchester University Press, Manchester, p.22

${ }^{6}$ Scammell (1999), p.718

${ }^{7}$ Quoted from Scammell (1999), p.725

${ }^{8}$ Scammell (1999), p.726
} 
Because marketing and politics are different in many ways, simply applying a marketing model to politics without considerable adaptation may not work. LeesMarshment described political marketing as a 'marriage' between politics and marketing; it is created by applying marketing concepts from business to politics, but not by simply imposing one over the other.' 9

\subsection{Why has political marketing emerged?}

This change towards voter-centred politics has coincided with social changes in the later part of the twentieth century. This section covers:

- Voters becoming political consumers.

- Changes to political parties.

\section{Political consumers}

People have become more like consumers when making their political choices. As Lees-Marshment stated, political consumers are not only concerned about whom to vote for but they also have a different attitude towards politicians, they want to be more involved and consulted, question authority and they scrutinise outcomes. ${ }^{10}$

Scammell argued that citizenship can now be found in consumptions. As consumers we have greater power, 'we have options in how to spend our hardearned cash....We are better informed shoppers than ever before. Consumer rights and interest groups and their advice are now daily in our mainstream mass media.'11 The Body Shop founder Anita Roddick has also commented on the importance of the consumer to force political change:

Business has overtaken politics as the primary shaping force in society, which means consumers are voting every time they flex

\footnotetext{
${ }^{9}$ Lees Marshment (2009), p.26

${ }^{10}$ Lees-Marshment (2009), p.9

${ }^{11}$ Margaret Scammell (2000), 'The Internet and Civic Engagement: The Age of the Citizen-Consumer,'

Political Communication, vol.17, p.351
} 
their spending muscle, and that in turn makes the vigilance consumer into a powerful consumer, capable, as we have seen, of humbling even the likes of Shell and Monsanto. ${ }^{12}$

Lees-Marshment identified five effects of consumerism on politics:

1. Voters want a more tangible, rather than a rhetorical, product: hence the rise of pledge cards or contracts between the government and the people.

2. Voters want more evident and instant delivery.

3. Voters prefer achievement to aspiration, and pragmatic effectiveness to moral principal.

4. Parties and politicians need to convey their governing capability.

5. Political promises need to be costed and realistic. ${ }^{13}$

\section{Changes in political parties}

At the centre of democracies are political parties. In a parliamentary system parties are organisations that seek representation in parliament; they also compete with other parties for public office. Parties are made of individuals who broadly share a common view on policies and ideology. Traditionally, the role of a party is to simplify choices for the electorate; since different parties offer different policy programmes and visions to the electorate, voters choose the set of policies they favour by voting for a certain party.

Parties also historically informed and educated citizens by providing them with information on policies. This role has been taken over by the media, who now acts as an intermediary between parties and the electorate. In recent years the increased availability of information through the internet has allowed voters to bypass the media and go directly to the party's website for information. Parties also mobilise the electorate to participate in the democratic process through

\footnotetext{
${ }^{12}$ Quoted from Scammell (2000) p. 351

${ }^{13}$ Lees-Marshment (2009), p.10
} 
election campaigns. Parties recruit leaders and provide training for future leaders. Parties determine who forms the government and once in office they can implement their policy objectives.

Even though the goals and functions of political parties have remained the same for generations, the organisation itself has transformed throughout the twentieth century. At the beginning of the twentieth century parties were old boys' network that essentially represented the interest of the rich and middle classes. The larger working classes were disenfranchised. However, in the early twentieth century this changed with the introduction of universal suffrage.

\section{The Mass Party}

The mass party model was devised by Duverger in 1954; it observed that political parties had emerged to represent different classes in society. Originally, the mass party was dominated by the newly enfranchised masses who had recently been allowed to participate in the political system. A party's mass membership legitimised a party's policy programme. A mass membership gave the party a source of funds as well as an army of volunteers to participate in election campaigns.

Due to the large working class base the mass party was originally a product of the left, but parties of the centre-right such as the British Conservative Party and the New Zealand National Party began to adopt a mass party appearance. The National Party, at its peak in the 1940s and 1950s, had 300,000 members, making it, per capita, the most successful mass party in the western world. The New Zealand Labour Party had 200,000 members, which meant that nearly one in three voters were members of political parties. ${ }^{14}$ The mass party was ideological in character and tried to advance the demands of the class group it represented rather than what the whole nation wanted.

\footnotetext{
${ }^{14}$ Raymond Miller (2005), Party Politics in New Zealand, Oxford University Press, Oxford, pp.73-74
} 


\section{The Catch-All Party}

In 1966, Otto Kirchheimer observed the rise of the catch-all party in the postWorld War II decades. After the war, strong ideological leanings were declining and parties responded by downplaying ideology. ${ }^{15}$ Parties changed their focus by trying to 'catch' the support of as many groups in society as possible. ${ }^{16}$

To become a catch-all party it needs to; (i) drastically reduce its ideological baggage. ${ }^{17}$ This frees the party from ideological constraints and gives it more flexibility in policy making; (ii) strengthen the leadership positions while reducing the role of the individual party member. ${ }^{18}$ Party members 'may obscure the newly built-up catch-all party image;'19 (iii) de-emphasis the party's special relationship with certain classes or groups and instead appeal to voters from the electorate at large, ${ }^{20}$ and; (iv) secure the support of a variety of interest groups for financial benefit. ${ }^{21}$

Kirchheimer understood that voters were now 'consumer-goods oriented' and the old politics that talked of drastic political changes was out of fashion. ${ }^{22} \mathrm{He}$ wrote that for parties to maximise their vote on election day:

the catch-all party must have entered into millions of minds as a familiar object fulfilling in politics a role analogous to that of a major brand in marketing of a universally needed and highly standardized article of mass consumption....There is need for enough brand differentiation to make the article plainly recognizable, but the degree of differentiation must never be so

\footnotetext{
${ }^{15}$ Otto Kirchheimer (1966), 'The Transformation of the Western European Party Systems', in J. LaPalombara \& M.Weiner (eds.) Political Parties and Political Development, Princeton University Press, New Jersey p.184

${ }^{16}$ Kirchheimer, p.186

${ }^{17}$ Kirchheimer, p.190

${ }^{18}$ Kirchheimer, p.190

${ }^{19}$ Kirchheimer, p.190

${ }^{20}$ Kirchheimer, p.190

${ }^{21}$ Kirchheimer, pp.190-191

${ }^{22}$ Kirchheimer, p.191
} 
great as to make the potential consumer fear he will be out on a $\operatorname{limb} .^{23}$

Kirchheimer noted that the main problem for a catch-all party is that party loyalty is fickle, any event or factor could change voters' minds like a television event or a speech. ${ }^{24}$ In 1988 , Panebianco added to the catch-all party model by proposing an electoral-professional party. Panebianco accepted Kirchheimer's model of the 'catch-all' party but he criticised Kirchheimer for not giving adequate attention to the increase of profesionalisation within party organisations. ${ }^{25}$ He stated that an electoral-professional party has professionals running the party at the centre. ${ }^{26}$ The party has weak ties to the grassroots members in order to catch as many voters as possible. 27 This party is funded though the public and interest groups. ${ }^{28}$ The party focuses on issues and leadership instead of ideology as with the mass party. ${ }^{29}$

\section{Market-Oriented Party}

A market-oriented party is the next step in the development of political parties. The market-oriented party has the same features of the catch-all party, for example the party is centralised and appeals to the centre. The market-oriented party goes one step further where it uses marketing techniques to find out what the voters wants. The key difference with this type of party is that the voter/political consumer is now placed at the beginning of the design process. The party shows 'this in the way they behave - or in the political product they design, offer and implement, in order to ensure the product satisfies market demands in order to achieve the desired goals.'30 I go into further detail about the market-oriented party in Chapter two.

\footnotetext{
${ }^{23}$ Kirchheimer, p.192

${ }^{24}$ Kirchheimer, p.193

${ }^{25}$ Angelo Panebianco (1988), Political Parties: Organization and Power, Cambridge University Press, Cambridge, p. 264

${ }^{26}$ Panebianco, p.264

${ }^{27}$ Panebianco, p.264

${ }^{28}$ Panebianco, p. 264

${ }^{29}$ Panebianco, p.264

${ }^{30}$ Lees-Marshment (2009), p.41
} 


\subsection{The Evolution of Political Marketing as an Academic Discipline}

Originally political science and marketing were two separate academic disciplines that had very little in common. Marketing is part of management science, which tends to focus on the goals, the organisation and the techniques of commercial businesses. ${ }^{31}$ Political science looks at areas such as party development, the structure of parties as well as elections, interest groups, government structures, leadership, political theory, etc.

In 1969 the idea that political science and marketing could come together as a sub-discipline was suggested, but not developed for some time afterwards. Kotler and Levy published an article suggesting that marketing could be applied to nonprofit organisations. ${ }^{32}$ This caused controversy among management scientists, some argued that such 'a combined semantic and territorial expansion may threaten the conceptual integrity of marketing, add to the confusion in terminology, and widen the gulf between marketing theory and practice.'33 However, during the 1970s marketing scientists starting developing theories and frameworks in which marketing could be applied to non-profit organisations. ${ }^{34}$ Political scientists then attempted to apply marketing concepts to political communications, which had it flaws because it focuses on political communication: on how politicians sell themselves, not how they behave; [and] it does not use marketing theory.' 35

In 1999, Scammell reviewed political marketing literature and concluded that studies on political marketing could be divided into three categories: Campaign studies, political communication and marketing management. ${ }^{36}$ Campaign studies are an area dominated by political scientists, focusing on electioneering and how campaigns have moved away from being labour-intensive and amateur

\footnotetext{
${ }^{31}$ Lees-Marshment (2001a), p.2

${ }^{32}$ Lees-Marshment (2001a), p.3

${ }^{33}$ Quoted from Lees-Marshment (2001a), p.3

${ }^{34}$ Lees-Marshment (2001a), p.3

${ }^{35}$ Lees-Marshment (2001a), p.4

${ }^{36}$ Scammell (1999), pp. 719-723
} 
exercises to a capital-intensive and professional operation. ${ }^{37}$ It is agreed that campaigns have been influenced by marketing and public relations consultants as well as advertising agencies, but criticisms about campaign studies stress that no theoretical framework has been devised to understand the effect of the campaign process. ${ }^{38}$

Political communications is another research area dominated by political scientists who investigate the effects of the media on civic engagement. In recent years the media has become a major influence in the lives of citizens; political organisations have attempted to adapt to this by changing, by focusing on media as an avenue to get their message out. This area of research focuses on political advertising as well as image creation. ${ }^{39}$ Political communications is important because it examines the transformation of the media from a minor political role to the major player in campaigning. 40 Scammell noted that political communications is primary concerned about a 'media effect' on the political process. ${ }^{41}$ Both campaign studies and political communications treat political marketing as one part of a much broader process. ${ }^{42}$

Marketing management is an area of research dominated by management and marketing scientists. ${ }^{43}$ Here the emphasis is shifted from 'techniques of promotion to the overall strategic objectives of the party/organization.' ${ }^{44}$ Marketing management is primarily concerned with marketing strategies in order to understanding the political market. ${ }^{45}$ Marketing management sees political communications as just one part of political marketing. ${ }^{46}$

\footnotetext{
${ }^{37}$ Scammell (1999), pp.719-720

${ }^{38}$ Scammell (1999), p.720

${ }^{39}$ Scammell (1999), pp. 721-722

${ }^{40}$ Scammell (1999), p.721

${ }^{41}$ Scammell (1999), p.722

${ }^{42}$ Scammell (1999), p.720

${ }^{43}$ Scammell (1999), p.722

${ }^{44}$ Scammell (1999), p.723

${ }^{45}$ Scammell (1999), p.723

${ }^{46}$ Scammell (1999), p.723
} 
These areas of political marketing, campaign studies and political communications, which focused on empirical research, failed to produce proper academic frameworks. They also overlooked the marketing concept in their analysis. Lees-Marshment took political marketing to a new level of theoretical abstraction; in her analysis she saw the short comings of the above areas of political marketing and developed a comprehensive political marketing model. ${ }^{47}$ This model brings marketing and political science literature together in one theoretical framework. ${ }^{48}$ Chapter two provides further detail of the comprehensive political marketing model.

\subsection{Criticism of Political Marketing}

Many academics and commentators are still sceptical about political marketing as an area of study; Hennneberg observed that political marketing is 'under an obligation to justify itself and to defend itself against criticism of its research ethos, i.e. the use of marketing concepts and instruments in the political sphere.' 49 He also noted that 'research on political marketing is sometimes condemned per se purely due to its link with political marketing practice that is seen as harmful to our democratic party political systems.' 50 The section below explains why political marketing is an important area of research.

\section{Political Marketing is all about spin}

In his 2004 article, Henneberg evaluated the common criticisms that commentators and academics have made about political marketing. He observed that academics and commentators alike argue that 'political marketing has transformed politics into being obsessed with 'spin' and 'packaging."51 This is a common criticism about political marketing; critics have accused it of being primarily concerned with image creation and the maintenance of that image. The consequence of this is a hollowed-out party/candidate who is all style with no

\footnotetext{
${ }^{47}$ Lees-Marshment (2001a), p.4

${ }^{48}$ Lees-Marshment (2001a), pp.4-5

${ }^{49}$ Stephen C. Henneberg (2004) 'The View of an Advocatus Dei: Political Marketing and its Critics,' Journal of Public Affairs, vol.4:3, p.225

${ }^{50}$ Henneberg (2004), p.226

${ }^{51}$ Henneberg (2004), p.228
} 
content. It is true that there has been an increase of consultants within governments and political parties, but this is a reaction to the 24 hour seven days a week media environment.

Henneberg observed that in the electoral market parties/candidates offer a programme to voters; voters vote for the party/candidate that they prefer and they then gain political office; if they fail to deliver that programme voter dissatisfaction occurs and voters will then change their behaviour by not participating in the electoral market or by supporting another party/candidate. ${ }^{52}$ Henneberg argued that it is naïve to assume that the electorate is ignorant enough to ignore broken promises because sophisticated marketing tools have 'tricked' them into forgetting its record. ${ }^{53}$ Political marketing techniques, which are still unsophisticated, should not have a much stronger influence on behaviour and attitudes than (extremely sophisticated and optimised) commercial marketing. ${ }^{54}$

This criticism argued that packaging is a central feature of political marketing. Indeed, image does play an important role in the political communications side of political marketing as Scammell observed:

Parties/candidates...must attend to political image if they want to be serious players in the political market. This is not an optional extra, nor simply a response to media power nor an effect of American influence; it is a strategic imperative of the political market. Reputation, based on record and credible promises, it the only thing of substance that a party can promote to potential voters. Thus, the marketing perspective not only explains the apparent political obsession with image, it more clearly locates the significance of the media. In this view of

\footnotetext{
${ }^{52}$ Henneberg (2004), p.230

${ }^{53}$ Henneberg (2004), p.231

${ }^{54}$ Henneberg (2004), p.231
} 
promotion and image-building do and must respond to the specifics of media systems and reporting styles. ${ }^{55}$

As mentioned above, if the package does have substance to it, it simply would not succeed in the long term. Political image created though rhetoric and style is nothing new. Rhetoric and oratory has been a feature of political life from ancient Greece through to the modern era. Even Machiavelli stressed the importance of having the right style and image (even though he does advocate style over substance):

A prince, therefore, need not necessarily have all the good qualities I mentioned...but he should certainly appear to have them. I would even go so far as to say that if he has these qualities and always behaves accordingly he will find them harmful; if he only appears to have them they will render him service. ${ }^{56}$

Political packaging through image and rhetoric is a historical and modern reality of politics; political marketing did not create this.

Henneberg's statement also accused political marketing of being obsessed with 'spin' the accusation that candidates and parties manipulate the media by moulding their messages through an emphasis on the positive, regardless of how good or bad the situation is. Political parties and other political institutions face a different media environment to that of commercial businesses. O'Shaughnessy argued that ultimately the media is more powerful, 'with their own agendas of information manufacture the media are often more influential on public opinion

\footnotetext{
${ }^{55}$ Scammell (1999), p.729

${ }^{56}$ Niccolò Machiavelli (2003) The Prince, George Bull (Translator), Penguin Books, London p.57
} 
than political advertising and other communications techniques of commercial derivation.' ${ }^{57}$

In contrast, according to O'Shaughnessy, spin is a stranger to commercial marketing, 'it is comparatively rare that a business will need the arts of 'spin' in communicating with its public. 58 Therefore, spin is not a concept that marketing has given to politics, it is rather, a political reaction to the more hostile media.

This criticism can be taken a step further where people do not distinguish the difference between political marketing and political propaganda. O’Shaughnessy stated that: 'Propaganda is not synonymous with persuasion and is a distinctive branch or high-pressure advocacy.'59 It 'simplifies and exaggerates; it often is propelled by a clear, purposive, and coherent ideology. Idealism, even utopianism, may motivate its sponsors and often may characterize its imagery.'60

O'Shaughnessy argued that there are some minor similarities between marketing and propaganda, but these two are extremes of a continuum. ${ }^{61}$ Both marketing and propaganda focus on the presentation of utopian vistas or ideal types to satisfy the aspirations of reference groups.'62 But O'Shaughnessy's main argument in his 1999 article is that the term political marketing in too narrow to look at this area. He argued that the term 'political marketing-propaganda' maybe a more useful term when focusing on this area of political marketing. ${ }^{63} \mathrm{In}$ commercial marketing situations there are few cases where negative advertising on similar to negative political advertising would take place, political advertising can place an 'emphasis on polarities, vilifications of enemies, and value conflicts, coupled with its need to create and sustain social discontent, [it] has

\footnotetext{
${ }^{57}$ Nicholas O'Shaughnessy, (2001) 'The Marketing of Political Marketing,' European Journal of Marketing, vol. 35 9/10, p.1047

58 O’Shaughnessy (2001), p.1051

${ }^{59}$ Nicholas. O'Shaughnessy (1999) 'Political Marketing and Political Propaganda' in Bruce .I Newman, (ed.)

Handbook of Political Marketing, Sage Publishing, Thousand Oaks p.727

${ }^{60}$ O’Shaughnessy (1999), p.727

${ }^{61}$ O'Shaughnessy (1999), p.725

${ }^{62}$ O'Shaughnessy (1999), p.725

${ }^{63}$ O'Shaughnessy (1999), p.726
} 
recognizably far more in common with war propaganda than the selling of a product or service.' 64

O'Shaughnessy observed that political marketing and political propaganda is different because political marketing 'replicate[s] most of the processes involved in consumer research, market research, advertising, personal selling, product management and so on - and this would make it an almost exclusively post second world war phenomenon.'65 Political propaganda does not place the citizen first; rather political propaganda is designed to manipulate and shape citizens opinions by using emotive and nationalistic language. At the Nuremberg trials, Hermann Goering remarked that:

people don't want to go to war....But, after all, it's the leader of the country who determines the policy and it's always a simple matter to drag the people along whether it's a democracy or a fascist dictatorship....Voice or no voice, the people can always be brought to do the bidding of the leaders. This is easy. All you have to do is tell them they are being attacked and denounce the pacifists for lack of patriotism and exposing the country to greater danger. It works the same in any country. ${ }^{66}$

Goering's remarks illustrated the stark difference between political propaganda and political marketing. Goering talked about the leadership making the choices, then using manipulation to get the citizenry on board. Political marketing is centred on the marketing concept where the citizenry is consulted first in every step of the process.

\section{Politics is above marketing}

Another anti-political marketing comment made by Henneberg stated that: 'parties and politicians that use political marketing are using the wrong

\footnotetext{
${ }^{64}$ O’Shaughnessy (1999), p.726

${ }^{65}$ Nicholas O'Shaughnessy (1990) The Phenomenon of Political Marketing, MacMillan Press, London p.17

${ }^{66}$ Quoted from Jason Epstein (2004) 'Mystery in the Heartland,' The New York Review of Books, October 7, p.8
} 
reference/mindsets. Politics is essentially not about 'selling' but about something completely different.'67 This criticism argued that one cannot equate electoral politics to selling soap power, for example, and that politics is a process that is different.68 Even though political parties have few similarities to normal consumer products, like televisions and iPhones, there are similarities between the promotion of parties and service marketing. Scammell outlines the similarities between a service and a political party:

the product is often intangible, complex and not fully understood by its customers....The buyer cannot physically see the product ahead of purchase, which in marketing terms means a relatively high uncertainty factor. Therefore s/he is heavily dependent on information, and depending on the cost/significance of the purchase, likely to seek out trusted information sources such as consumer watchdog media and persona recommendations from friends and colleagues. ${ }^{69}$

Service marketing is about building a relationship of trust and loyalty with consumers as well as selling a service. As a result political parties can and have found value in applying these concepts to politics because ultimately the aim of a political party is to build a long-term relationship with voters.

Since there are similarities between service marketing and political parties, what are the differences? In their analysis Lock and Harris have identified seven reasons why political marketing differs to conventional service and product marketing:

(1) The majority of voters cast their votes on election day. There is no equivalent purchasing decision in which consumers all have to make their purchase in one day.

\footnotetext{
${ }^{67}$ Henneberg (2004), p.228

${ }^{68}$ Henneberg (2004), p. 232

${ }^{69}$ Scammell (1999), p.727
} 
(2) The price of voting for one party is constant, while the price of purchasing varies depending on other factors. Every voter is entitled to one vote and one vote only, while in the consumer market price or purchasing is dependent on budget constraints and availability.

(3) The voter has to live with the collective decision of the electorate, regardless of who they voted for.

(4) In First Past the Post countries such as the UK, the winner takes everything, whether or not it is a local constituency of government. The market is fairer, in which companies still retain a market share. [When applied to proportional systems like New Zealand the electoral market is fairer and produces a proportional result; even though parties do have to cross a threshold of five per cent of the party vote or win one electoral seat to gain representation.]

(5) A political party or a candidate is a 'complex and intangible product that the voter cannot be unbundled.' Even though in service marketing the product is also complex, the consumer can change their minds about the performance of the service provider at a cost, while voters have to wait until the next election.

(6) It is harder for new parties to enter the party system then it is for a new product to enter the market.

(7) In marketing the brand or market leader constantly stays in front (if you consider sales an indicator of support), while in politics the governments support tends to fluctuate during its term in office. ${ }^{70}$

Service marketing and political parties have similar goals, and it is fair to argue that politics is about selling/promoting a service to the electorate.

\footnotetext{
${ }^{70}$ Andrew Lock and Phil Harris (1996) 'Political Marketing - Vive la Difference!' European Journal of Marketing vol.30 10/11 pp. 21-23
} 
In recent years academics have started building theoretical frameworks for political marketing. Jennifer Lees-Marshment has developed a theoretical framework called 'comprehensive political marketing', which applies both marketing and political ideas to parties, and moves beyond political communications by looking at how marketing influences the whole party as an organisation. ${ }^{71}$ In The Idea of Political Marketing, contributors theorised different models on how marketed parties compete with each other, how they interact with the political market, and why such models emerged. ${ }^{72}$ After establishing why political marketing is an inherently worthy topic to study, the next chapter turns to the product life-cycle model and how it can be adapted for political parties.

\footnotetext{
${ }^{71}$ Jennifer Lees-Marshment (2001a) Political Marketing and British Political Parties: The Party's Just Begun, pp.4-5

${ }^{72}$ Nicholas O'Shaughnessy and Stephan Henneberg (eds.) The Idea of Political Marketing, Praeger, Westport, CT.
} 


\section{The Product Life-Cycle Model}

Political parties have difficulties renewing themselves in office, especially after a long period of time in government. Eventually voters get bored or frustrated with a government and replace them with another party. There are numerous governments that failed to renew themselves, for example in New Zealand the Labour Government of Helen Clark, which was popular in its early days, failed to successfully regenerate itself and was removed. The preceding National Government of Jim Bolger and Jenny Shipley also failed to successfully regenerate despite changing its leader two years before the 1999 general election.

I use political marketing models and concepts and integrate them into the natural product life-cycle model of growth and decay. I adapt this model into a model that looks at the long term impact of political marketing on a party. I focus on these key questions:

- Can a market orientation be sustained during long periods in government?

- Can an adapted product life-cycle model be adapted to political parties?

- Does this model tell us anything new?

- What is the role of a party leader in this model?

Much of the literature about political marketing focuses on how marketing tools and marketing communication tools have been used to get a party elected to government or increase support. Even though these studies have added value to political marketing they only focus on a short period of time and do not have the scope of embracing the product life-cycle. For example the comprehensive political marketing model looks at a 'political product' during a term of office which is around three to five years, and then the cycle is repeated. My thesis builds on the political marketing models and concepts already developed by other academics and marketers. 
This chapter outlines the product life-cycle model. Secondly, I outline a number of political marketing models and concepts which is used in my New Labour case study. The models and concepts discussed are:

- Comprehensive political marketing.

- Marketing positioning.

- Brand narratives.

- Brand agents.

Finally, this chapter brings together the essence of these ideas and outline a product life-cycle model which incorporates political parties. This proposed model is then be tested by my case study to follow.

\subsection{The Product Life-Cycle Model}

When a product is launched, marketing managers know that their product will not sell forever and successful products go through a life-cycle that consists of five stages: product development, introduction, growth, maturity and decline. A successful political party or political 'product', generally speaking, goes through similar stages, being introduced and gaining support, becoming the opposition, becoming government, losing support in government and returning to opposition.

Kotler and Armstrong described these cycles in greater detail:

Product development begins when the company finds and develops a new-product idea. During production development, sales are zero, and the company's investment costs mount.

Introduction is a period of slow sales growth as the product is introduced in the market. Profits are non-existent in this stage because of heavy expenses of product introduction. 
Growth is a period of rapid market acceptance and increased profits.

Maturity is a period of slowdown in sales growth because the product has achieved acceptance by most potential buyers. Profits level off or decline because of increased marketing outlays to defend the product against competition.

Decline is the period when sales fall off and profits drop. ${ }^{73}$

This model is illustrated below:

\section{Figure 2.1 The Product Life-Cycle}

\section{Sales}

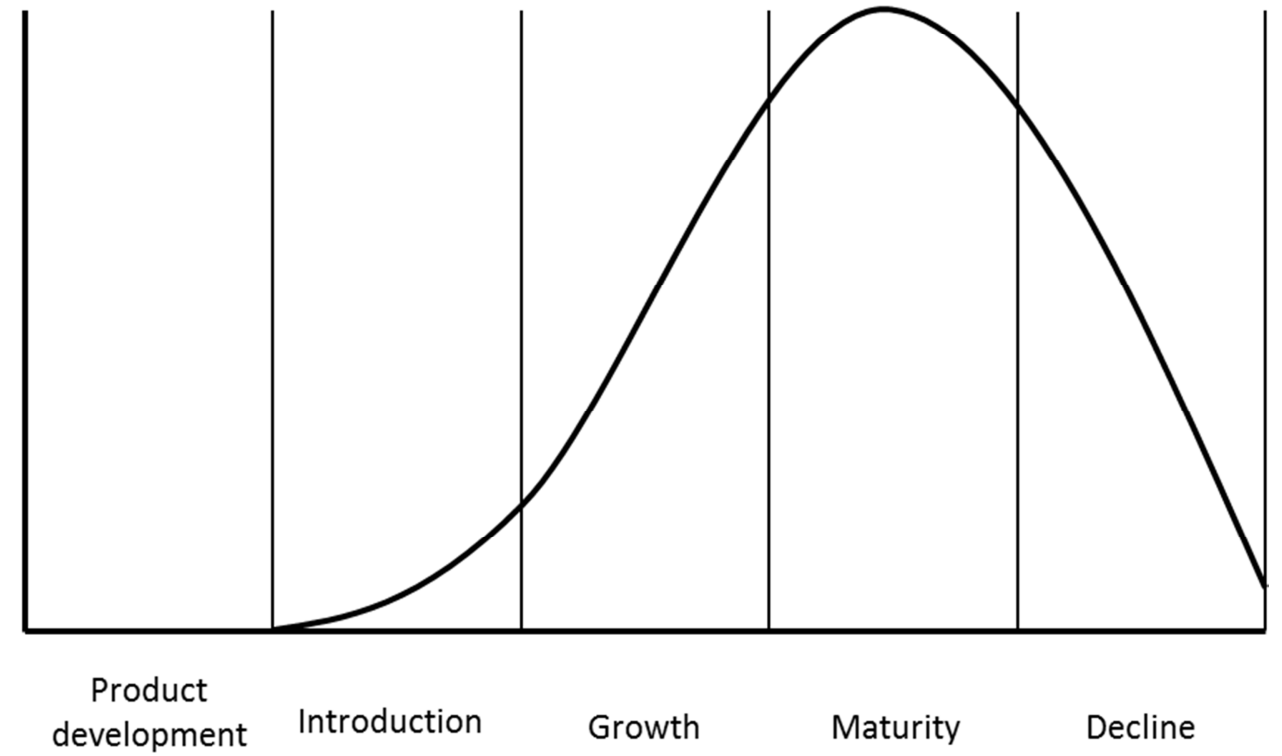

Time

Source: Kotler and Armstrong (2012)

Kotler and Armstrong observed that not all products follow the above cycles equally. ${ }^{74}$ Some products are introduced then decline; others may mature for a long time.

\footnotetext{
${ }^{73}$ Philip Kotler and Gary Armstrong (2012), Principles of Marketing (14 ${ }^{\text {th }}$ Edition) Peason p.273
} 
The product life-cycle model can be related to a political party by assuming that the 'product' is a political party. A political party develops when a community with common ideals come together and they have another view to offer the political market. At first its 'sales' or support is very low. For instance the British Labour Party was formed by groups like trade unions and the Fabian Society. It had low support in the 1900 general election where it stood just 15 candidates and won only two seats. In 1906 the party stood 50 candidates and won 29 seats. The 'cost' for a new party to break into an established political market is high. This fits in with the product development stage and the introduction period described by Kotler and Armstrong. The party is developed but had a typical slow introduction to the political market.

The growth stage is when the party becomes a serious player. It is the 'challenger' in the political market and eventually gains enough support to become the market leader. For example, the New Zealand Labour Party became a serious player between the 1931 and 1935 elections, picking up support from the governing coalition during the depression. Labour won government in 1935 with 53 seats compared to 24 seats from the previous election. Labour's growth into suburban and provincial New Zealand enabled it to become the 'market leader.'

The maturity stage is the market leader in government. A party has gained enough support or 'profit and market acceptance' to govern and deliver its programme and policies. It continues to build its relationship with political consumers by delivering on promises it could not deliver in earlier stages. However, the market leader faces the realities of being in government. Its relationship with the political consumer is in 'competition' with other players, domestic as well as foreign governments, or in response to unforseen events like an economic downturn or disaster. Support for the market leader becomes static and eventually declines. In the maturity stage the product should be thinking

${ }^{74}$ Kotler and Armstrong (2012), p. 273 
about rejuvenation, to stay fresh it should introduce new features, in politics this could include introducing a new leader, a major cabinet reshuffle or a new policy direction.

The decline stage is when a market leader loses its position and is overtaken by the challenger. This is the period when it is certain that the market leader is about to leave government. Its decline may continue further while in opposition and electoral rules may influence the degree or magnitude of its decline (for example, First Past the Post vs Mixed Member Proportional).

At this point a political party may be rejuvenated by being reintroduced into the introduction cycle, or by going through another growth period, which is the common occurrence in systems like Australia, New Zealand and the United Kingdom. For example the Conservative Party in the United Kingdom lost office in 1997 in a landslide, it stayed in the wilderness for two more elections before it regained its position as market leader at the 2010 election. Or a party may face a sharp decline and death, such as the Progressive Conservative Party of Canada which was booted out of office in 1993 after it went from 169 seats to two, before being dissolved in 2003 .

\subsection{Comprehensive Political Marketing}

By merging political science and marketing theories, Lees-Marshment developed

a framework she calls, Comprehensive Political Marketing (CPM). This framework is useful because:

1. CPM views marketing as more than simply political communications.

2. CPM applied marketing to the whole behaviour of a political organisation.

3. CPM uses marketing concepts, not just techniques: the product, sales and marketing orientation as well as market intelligence, product design and promotion. 
4. CPM integrates political science literature into the analysis.

5. CPM adapts marketing theory to suit the differing nature of politics. ${ }^{75}$

CPM is focused around three types of political organisations derived from business organisations. In the business world an organisation may be classified as one of the following: product-orientated business, which is where a business designs a product and believes that the strength of that product will sell itself. ${ }^{76}$ A sales-oriented business has the same attitude about the design of the product, but it uses marketing techniques such as advertising to draw people towards that product. ${ }^{77} \mathrm{~A}$ market-oriented business uses market research to design the product, and like the Sales-Oriented Business, it uses marketing to promote the product to consumers. ${ }^{78}$ Lees-Marshment applied this frame work to political parties and theorised about three types of party: the product-oriented party, the sales-oriented party and the market-oriented party.

\section{The Product-Oriented Party (POP)}

The product-oriented party, like its business counterpart, is primarily focused on its product. It believes that the strength of its product will sell itself and will not be altered to gain electoral support. ${ }^{79}$ The party develops its policies and programmes on its own accord. This is a traditional approach made by political parties where they develop a party product that is based on ideological convictions and principals, rather than finding out what the electorates wants through market research. For example, a party like the Green Party would develop its product on its beliefs about environmentalism; they trust that the electorate, sharing their concerns, sees the merit of their product for what it is. The British Labour Party historically took this approach, relying on the voters of

\footnotetext{
${ }^{75}$ Lees-Marshment (2001a), pp.4-5

${ }^{76}$ Jennifer Lees-Marshment (2001b), 'The Marriage of Politics and Marketing,' Political Studies, vol.49:4, p.695

${ }_{77}$ Lees-Marshment (2001b), p.695

${ }^{78}$ Lees-Marshment (2001b), p.695

${ }^{79}$ Lees-Marshment (2001a), p.28
} 
its traditional coalition of the working class and trade unions at a time when these two groups were well represented in British society. Lees-Marshment described the British Labour Party's 1983 campaign as the most recent example of the party using a product oriented campaign where the leader, Michael Foot, was more concerned about party unity than reflecting voter opinion. ${ }^{80}$

\section{The Sales-Oriented Party (SOP)}

The sales-oriented party is similar to a product oriented party because the product is developed by what the party thinks is ideal, but it uses marketing techniques like advertising to attract and persuade voters. ${ }^{81}$ After the party determines its own product it then uses market research to test how the electorate feels about the party's product. Market intelligences can be determined informally or formally. Informal intelligences involves 'keeping an ear to the ground'; talking to party members; creating policy groups; and holding general meeting with the public. Since the party knows how people are going to react to the party's programme they can develop a communications strategy to sell and persuade the electoral market.

Lees-Marshment used the example of the British Labour Party under Neil Kinnock (1983-1992) as an example of a sales-oriented party. Following the 1983 election the party adopted a professional image using the red rose as its logo. The party conducted qualitative research and centralised its communications. ${ }^{82}$ Lees-Marshment concluded that Labour's version of a sales-orientated party failed because the party "needed to pay more attention to the product it was conveying, and more attention to the desires of the voters that it was seeking to govern.' 83

\footnotetext{
${ }^{80}$ Lees-Marshment (2009), p.67

${ }^{81}$ Lees-Marshment (2001a), p.29

${ }^{82}$ Lees-Marshment (2001a), p.158

${ }^{83}$ Lees-Marshment (2001a), p.179
} 


\section{The Market Oriented Party (MOP)}

This party is different to the other two parties because it used market research to develop its product, but like the sales-oriented party it does use marketing techniques to communicate its message. According to Lees-Marshment's framework, a market-oriented party:

- Gains market intelligence from informal sources such as town hall meetings and having discussions with party members and voters so they can find out what the electorate wants and get a feel of why people may or may not vote for them; 84

- Uses formal market intelligence by quantitative sources, such as polling, or qualitative sources, such as focus groups, to help reveal voter's long term demands; 85 and

- 'Design its 'product' according to the findings from its market intelligence to suit electoral demand.' ${ }^{86}$ At this stage of the process the party looks at changing itself to reflect the findings of its market intelligence, these changes can be small changes or dramatic changes, depending on the state of the original party.

The product is adjusted in order to suit the party, keeping in mind:

1. Achievability: the party should not promise what it cannot deliver in government.

2. Internal reaction: the party should change the design to ensure that it will obtain the support of enough MPs and members to ensure its implementation.

3. Competition: the party should find out the opposition's weakness and highlight its own corresponding strengths.

\footnotetext{
${ }^{84}$ Lees-Marshment (2001a), p.32

${ }^{85}$ Lees-Marshment (2001a), p.32

${ }^{86}$ Lees-Marshment (2001a), p.33
} 
4. Existing/needed support: the party should focus on winning the support of voters it does not have but needs to win power. 87

If the market-oriented party wins office it needs to deliver on its policies. LeesMarshment observed that:

Delivery is crucial to the ultimate success of marketing and therefore political marketing. In their discussion of business organisations, Moynihan and Titley note that production is not complete until the good or service reaches the consumer, who is likely to want to receive it as quickly as possible and warn that an 'organisation that is unable to satisfy these desires will not achieve its aims of expanding market share...There will be no repeat sale or customer loyalty from a dissatisfied customer.' In politics, if parties fail to deliver on policy promises, voters dissatisfaction is unlikely to decrease. In fact it may increase because voters were offered what they wanted but did not receive it. 88

Out of the three party types, the sales-oriented party and the market-oriented party both embrace political marketing. The sales-oriented party only partially uses marketing; it uses marketing for promotion, but not for determining the product. For a party to fully embrace political marketing, where the market concept is at the central place of the party's campaign and design a party would follow the strategies set out for a market-oriented party. Lees-Marshment's market-oriented party model gave a framework which a party follows to develop market-orientated policies and reflect the needs and the wants of political consumers. She stated that during the product design period that the marketoriented party should follow the findings of its market intelligence, the party:

\footnotetext{
${ }^{87}$ Lees-Marshment (2001a), p.34

${ }^{88}$ Lees-Marshment (2001a), p.40
} 
creates a model product design or picture as to how the party would behave if it followed voters' demands. This means changing, where necessary, not just the policy of a party but aspects such at its leader (or leadership style), the behaviour of the party's MPs and/or candidates for officer, organisational structure and membership rights. ${ }^{89}$

Lees-Marshment wrote that a common criticism of her model is that parties do not have a sole market, sales or product orientation. Instead, "parties often adopt a hybrid approach, implementing either sales or market-orientation, depending on the individual policy area.'90 This criticism can be addressed in a product lifecycle model, which assumes that parties have different orientations at different points in the cycle; during the introduction phase a new political product would have a more market oriented approach, as it matures, the market orientation may continue but parts of the product may have more of a sales orientation. As the party declines it may then even develop a product orientation.

For my version of the product life-cycle model, I apply the concepts of market orientation, sales orientation and product orientation to the party's product (policies and party structure) and the party's promotion (branding).

\subsection{Market Positioning}

A party's position in the political market determines the competitive strategic behaviour of that party. According to Collins and Butler there are four positions that a party can find themselves in: market leader, challenger, follower and nicher, these positions are determined by a party's market share in the political market. ${ }^{91}$ Collins and Butler pointed out that there are far less participants in the political market than in the commercial market.92

\footnotetext{
${ }^{89}$ Lees-Marshment (2001a), p.33

${ }^{90}$ Lees-Marshment (2009) p.49

${ }^{91}$ Neil Collins and Patrick Butler (2002), 'Considerations on Market Analysis for Political Parties,' in Nicholas O'Shaughnessy and Stephan Henneberg (eds.), The Idea of Political Marketing, Praeger, Westport, CT, p.6 ${ }^{92}$ Patrick Butler and Neil Collins (1996) 'Strategic Analysis in the Political Markets' European Journal of Marketing vol.30 10/11 p.35
} 


\section{The Market Leader}

In the business world the market leader is the player with the highest market share, companies such as Coca-Cola, Nike and Apple, etc. A player that has the position of market leader has three main competitive strategies; to expand the market, expand its market share or defend its market share. ${ }^{93}$ Parties in the position of market leader may find it hard to increase the political market, or find it difficult to expand its own market share because by virtue of being market leader it has already grown a broad voter base. ${ }^{94}$ But in politics it is vital for the market leader to develop strategies to defend its market share; the market leader is under consistent attack from other challengers in the market. ${ }^{95}$ The market leader also has to defend itself from attacks from external players like interest groups and the media, who are more hostile in the political market than they are in the commercial market.

\section{The Challenger}

The challenger is an organisation that aims to replace the market leader, in the commercial market there could be several challengers in the market, but in a Westminster style political market the challenger is the official opposition party. Collins and Butler stated that the challenger is a player that has chosen to attempt to depose the leader and has a realistic chance of so doing.'96 The main strategy of the challenger is to become the market leader; the challenger attempts to take some of the market share away from the market leader, but it may also try and take support from others in the market. For example, in the 2005 New Zealand General Election, National, as the challenger attempted to not only take votes away from the market leader Labour, but also took votes away from other players such as Act, United Future and New Zealand First.

There are different ways in which the challenger can try and position themselves as market leader; they can target the market leader directly, which Butler and

\footnotetext{
${ }^{93}$ Collins and Butler (2002), p.7

${ }^{94}$ Collins and Butler (2002), p.7

${ }^{95}$ Collins and Butler (2002)," p.7

${ }^{96}$ Collins and Butler (2002),p.9
} 
Collins argued this is a high-risk strategy but can provided high-payoffs. The challenger may adopt the strategies that the market leader had when it became market leader itself. There could be a head-on challenge which occurs when the competing products are very similar with each other. The 'back-door' strategy is when a party 'may identify issues on the horizon which become important and 'brand' these early.'97

The follower and the nicher are competitive strategies for smaller parties which are not relevant for my case study. However, for a complete view of Collins and Butler's model I outline them below:

- The follower occurs in industries where the differentiation possibilities are limited' but the returns are satisfactory for companies to take part in this market. ${ }^{98}$ The follower clones the leader but they make a slight variation to the leading product. ${ }^{99}$ In the political world this situation occurs in multi-party systems where smaller parties seek to become a suitable partner for the market leader in order to gain some polices and/or cabinet positions.

- The nicher is a type of business/party that attracts only a small amount of business/votes through conceptual targeting. They have a high profile, but can easily disappear or get overtaken by other businesses or parties. ${ }^{100}$

In the product life-cycle model a political product may either be a challenger or the market leader. During product development, introduction and decline cycles the product would most likely be in opposition and a challenger in the political market. The growth stage is where the political product gets the momentum to become the market leader. The maturity stage is where the political product's support starts declining and it makes the transition from market leader back to challenger.

\footnotetext{
${ }^{97}$ Collins and Butler (2002),p.10

${ }^{98}$ Collins and Butler (2002),p. 11

${ }^{99}$ Collins and Butler (2002),p.11-12

${ }^{100}$ Collins and Butler (2002),p.13
} 
Collins' and Butler's analysis of the 'market leader' and 'challenger' is only applicable to a broad appealing market-oriented party. A market-oriented party would behave differently depending on its current position in the political market. Collins and Butler stated that the market positions in the political market are defined by the last election and are therefore fixed until the next election. ${ }^{101}$ They argued that even though opinion polls are an important reflection of the electorates view, the market positions do not change until an election. ${ }^{102}$

\subsection{Branding}

This section looks at the branding of a political product. Lees-Marshment's comprehensive political marketing model focused on the design of the political product. Collins and Butler's model looked at the product's strategy and branding is about the product's communications. This section examines the following areas:

- What is branding and how can it be applied it to politics?

- What makes a successful brand?

- Applying branding to the product life-cycle model.

- Brand narratives / brand agents.

It is important that a political product, whether it is in opposition or in government, portrays an image of a competent party that has the ability to deliver its policies. In marketing terms a political party has more in common with a service than it does with a consumer item. Services are intangible and complex, the consumer does not know what they are getting until the service is delivered, they are 'sold on trust - the belief that the supplier will offer future satisfaction.' 103 Since services are delivered by people the quality of the service varies from provider to provider, even if the provider works for the same

\footnotetext{
${ }^{101}$ Collins and Butler (2002), p.6

${ }^{102}$ Collins and Butler (2002),p.6

${ }^{103}$ Martin Harrop (1990) ‘Political Marketing' Parliamentary Affairs,' vol.43:3p.278
} 
organisation. Essentially a party is the same; it is intangible, it is voted for on voters' trust about the party's ability to deliver, and parties need to invest effort and use marketing techniques to create a credible image so that voters feel confident voting for that party.

Harrop argued that when choosing who to vote for, political consumers 'venture round the political supermarket, settling on the party which provides the most items from their shopping list.'104 Political consumers are also concerned about a party's ability to realistically deliver its policies; 'What most clients want from service companies is not policies but results. As long as an investment manager produces a good return, who cares what the investment philosophy is?'105 This means that political consumers are more interested in having their own concerns looked after than a party's ideology. Branding can be used to reassure political consumers that their vote will not be wasted and policies to address their concerns can be delivered by a political product.

Branding was developed in the nineteenth century to identify mark property and ownership, and identify the origin and content of goods.'106 However, recently brands have become more sophisticated with 'different values, meanings and reputations.' 107 Moor noted that: 'Branding has also come to act as the basis for the launch of new products and as a focus for consumer identification and aspirations, and has been extended outwards from the product into a wider range of materials and environments.' 108

A brand is not tangible and in some cases it can takes years for a brand to build a positive reputation. Branding can also be applied to political products. LeesMarshment described branding as being:

\footnotetext{
${ }^{104}$ Harrop, p. 280

${ }^{105}$ Harrop, p. 278

${ }^{106}$ Liz Moor (2007), The Rise of Brands, Berg, Oxford, p.15

${ }^{107}$ Moor, p.15

${ }^{108}$ Moor, p. 15
} 
about how a political organisation or individual is perceived overall. It is broader than the product; whereas a product has a functional purpose, a brand offers something additional, which is more psychological and less tangible. It is concerned with impressions, attitudes and recognition. Branding helps the party or candidate to help change or maintain reputation and support. 109

Branding has also been used by governments. Van Ham stated that:

Brand managers offer four arguments why branding is both necessary and beneficial for commercial and political actors alike: (1) products, services and locations have become so alike that they can no longer differentiate themselves by their quality, reliability and other basic traits. Branding adds emotion and trust to these 'products', thereby offering clues that make consumers' choices somewhat easier; (2) this emotional relationship between brand and consumer ensures loyalty to the brand; (3) by creating an aspirational lifestyle, branding offers a kind of Ersatz for ideologies and political programmes that have lost their relevance; and (4) the combination of emotions, relationships and lifestyles (values) allows a brand to charge a price premium for their products, serves and locations, which would otherwise hardly be distinguishable from generics. ${ }^{110}$

Needham added that not only does a political brand need to gain a good reputation before it is elected, but once elected the party needs to maintain a good relationship with the political consumer in order to reassure the voter that they had made the right choice at the last election. ${ }^{111}$ Needham argued that even

\footnotetext{
${ }^{109}$ Lees-Marshment (2009), pp.111-112

${ }^{110}$ Van Ham (2002), pp.251

${ }^{111}$ Catherine Needham (2005), 'Brand Leaders: Clinton, Blair and the Limitations of the Permanent Campaign,' Political Studies, vol.53 p.346
} 
though relationship marketing is useful in image creation, branding is a more useful concept because it:

combines three elements - internal values, external presentation and consumer perception - whereas alternative terms such as reputation and image are less encompassing. Reputation is a blend of internal values and consumer perception, but gives little insight into external presentation. Image is a combination of external presentations and consumer perception, but does not have a values component....Branding is a more robust concept because the elements of effective branding can be distilled from commercial literature and utilised in political analysis. Branding is relevant to election campaigning, but is particularly helpful in understanding efforts to sustain relationships and maintain loyalty during the period between elections. ${ }^{112}$

Needham identified six attributes of a successful brand which can be transferred to politics ${ }^{113}$ Brands:

1. simplify information so that the consumer do not have to go through detailed product information when making a decision.

2. are distinctive and different from their competitors, especially in a market where there are two similar products. In some cases the product is almost identical with the competitor, but the attributes of the brand made it unique.

3. minimises the possible of risk, 'an effective brand is reassuring, a guarantee of standardisation and replicability....Reassurance given by a brand is one of the explanations for people's willingness to pay more for branded goods than non-branded'. ${ }^{114}$

\footnotetext{
${ }^{112}$ Needham, p.347

${ }^{113}$ Needham, pp.347-348

114 Needham, p.348
} 
4. 'are aspirational, evoking a particular vision of the 'good life' and holding out the promise of personal enhancement based on a set of values.'

5. represent the values of the product or the company "providing clear and consistent reasons why consumers should buy that product rather than another.'115

6. 'are perceived as credible, delivering on their brand promise.'116

Needham applied these attributes to Blair and Clinton and found that their brands did attempt to simplify, be unique, reassure, aspire, show values and show credibility. ${ }^{117}$

\section{Applying branding to the product life-cycle model}

Through my research, I have found brand concepts that could be applied to a political version of the product life-cycle model. In the first model focuses on the brand strategies that a product can use during the product life-cycle. The second looks at brand narratives used by a product, which varies between different points of the cycle and also identifies the role of brand agents and their relationship with the brand.

\section{Brand Strategies}

Rajagopal and Sanchez applied the product life-cycle model to their review of brand management. Their model is as follows ${ }^{118}$ :

\footnotetext{
115 Needham, p.348

${ }^{116}$ Needham, p.347

${ }^{117}$ Needham (2005), p.357

${ }^{118}$ Rajagopal and Romulo Sanchez, (2004) "Conceptual Analysis of Brand Architecture and Relationships within Product categories" Journal of Brand Management, vol.11:3 pp.243-244
} 


\begin{tabular}{|c|c|c|c|c|}
\hline \multicolumn{5}{|c|}{ Figure 2.2 Brand strategies } \\
\hline $\begin{array}{l}\text { Strategy } \\
\text { Options }\end{array}$ & $\begin{array}{l}\text { Brand } \\
\text { development }\end{array}$ & $\begin{array}{l}\text { Brand } \\
\text { reinforcement }\end{array}$ & $\begin{array}{l}\text { Brand } \\
\text { reposition }\end{array}$ & $\begin{array}{l}\text { Brand } \\
\text { redesign }\end{array}$ \\
\hline Objectives & $\begin{array}{l}\text { Establish } \\
\text { market } \\
\text { position }\end{array}$ & $\begin{array}{l}\text { Expand target } \\
\text { market }\end{array}$ & $\begin{array}{l}\text { Secure new } \\
\text { market } \\
\text { segments }\end{array}$ & $\begin{array}{l}\text { Prepare for re- } \\
\text { entry }\end{array}$ \\
\hline Product & $\begin{array}{l}\text { Assure high } \\
\text { quality }\end{array}$ & $\begin{array}{l}\text { Identify } \\
\text { weakness }\end{array}$ & $\begin{array}{l}\text { Adjust } \\
\text { features }\end{array}$ & $\begin{array}{l}\text { Modify weak } \\
\text { features }\end{array}$ \\
\hline Promotion & $\begin{array}{l}\text { Build brand } \\
\text { awareness }\end{array}$ & $\begin{array}{l}\text { Provide } \\
\text { information }\end{array}$ & $\begin{array}{l}\text { Communicate } \\
\text { new features }\end{array}$ & $\begin{array}{l}\text { Educate on re- } \\
\text { entry features }\end{array}$ \\
\hline Distribution & $\begin{array}{l}\text { Build } \\
\text { distribution } \\
\text { network }\end{array}$ & $\begin{array}{l}\text { Strengthen } \\
\text { channel } \\
\text { relationship }\end{array}$ & $\begin{array}{l}\text { Deliver all } \\
\text { versions }\end{array}$ & $\begin{array}{l}\text { Smoothen } \mathrm{re}^{-} \\
\text {entry } \\
\text { problems }\end{array}$ \\
\hline Pricing & $\begin{array}{l}\text { Skimming or } \\
\text { penetration }\end{array}$ & $\begin{array}{l}\text { Challenge } \\
\text { competition }\end{array}$ & $\begin{array}{l}\text { Use good price } \\
\text { deals }\end{array}$ & $\begin{array}{l}\text { Reduce prices } \\
\text { to clear stocks }\end{array}$ \\
\hline $\begin{array}{l}\text { Product life- } \\
\text { cycle }\end{array}$ & Introduction & Growth & Maturity & Decline \\
\hline & & & & \\
\hline
\end{tabular}

Source Rajagopal and Sanchez (2004)

The above model is a marketing model and 'pricing' and 'distribution' do not easily fit into a political context. However, 'objectives', 'product' and 'promotion' can be applied to a political model. As a political product is introduced in the political market, its brand is being developed, its goal is to establish itself a position in the political market by attracting support and through its communication channels it is informing the political market of this. The political product at this point already has some support from party members and loyal supporters.

When the political product enters into the growth stage, it seeks to expand its support, for example to try and take voters away from the market leader. As the 
product has been in the market place for some time weaknesses should be identified. Further information about the product should be provided to voters. For example, New Labour expanded its support by targeting policy areas that the Conservative Party was considered strong in, such as law and order. The brand is re-enforced and weaknesses in the product should be appearing.

During the maturity phase, the goal of the brand is to reposition itself. In political terms this would be a government that has been in power for a while. The objective in this part of the cycle is to maintain the support that has already been built for the political product. However, the product needs to be readjusted and those new features need to be communicated. These adjustments should be done after market research and could consist of a change in policy direction or change in leadership.

During the decline part of the cycle, the product has lost its position as market leader and needs to start preparing itself for re-entry in the market. The weak features of the product need to be changed. Political parties are large, complex organisations, so the decline and successful re-entry from opposition to government can take a long time. This phase can unleash tensions within a political party, for example it took the British Labour Party 18 years to get back into power after its 1979 defeat, likewise, it took the Conservative Party 13 years to get back into power after its 1997 defeat.

\section{Brand narratives / brand agents}

In his 2002 work, Legendary Brands, Laurence Vincent wrote about how some brands become legendary while other brands are just ordinary product brands. The difference between these two kinds of brands is that legendary brands use a brand mythology which:

uses narrative to convey a worldwide, set of sacred beliefs that transcend functional and epistemic product attributes. This narrative, which connects the consumer and the brand in a kind 
of existential bond, is the foundation of the brand's strength. Brand mythology operates in a self-fulfilling cycle that engages consumer participation. ${ }^{119}$

Vincent's work can be applied to the product life-cycle model. Political products use narratives to emphasis the attributes of the product and these narratives change during the different stages of the product life-cycle. Vincent's work on the brand agent is an important concept because it deals with the relationship between a political brand and a political leader, this relationship changes, at some points in the cycle the political brand / leader is stronger while the brand agent / leader is weaker and vice versa.

\title{
Brand narratives
}

As stated above, branding can be applied to a political product, Vincent agreed with this statement and he went further by arguing that narratives can be attached to political campaigns because "political campaigns are stories. They are specifically stories about a Legendary Brand - the candidate [or party].' ${ }^{120} \mathrm{He}$ further stated that:

\begin{abstract}
Any good political consultant knows that the difference between the client and the opposition is often miniscule. It is no surprise that the first angle of attack in a political campaign is to build a story around the candidate that provokes emotion from the constituency ${ }^{121}$.
\end{abstract}

Vincent identified the difference between a story and a narrative. A story is in chronological order, it has a three-act structure with a situation, complication and resolution; the aim of the structure is not to create conflict but resolve that

\footnotetext{
${ }^{119}$ Laurence Vincent (2002) Legendary Brands: Unleashing the Power of Storytelling to Create a Winning Marketing Strategy, Dearborn, Chicago, p.19

${ }^{120}$ Vincent, p.289

${ }^{121}$ Vincent, p.32
} 
conflict. ${ }^{122}$ On the other hand, narrative is told by a narrator and 'adds a point of view to the story.' This means that 'one story could have multiple narratives, each depending on the voice recounting it, and the point of view they select to frame the sequence of events. Narrative is the tool of the marketer; story is the tool of the reporter.' ${ }^{123}$

This is similar to psychologist, Howard Gardner who argued that narratives are an important dimension in leadership because they:

speak to both parts of the human mind - its reason and emotion. And I suggest, further, that it is stories of identities - narratives that help individuals think about who they are, where they come from, and where they are headed - that constitute the single most powerful weapon in the leader's literary arsenal. ${ }^{124}$

Gardner added that human beings subconsciously absorb stories, but whether or not the story gets embraced by the audience is dependent on the skill of the story teller. ${ }^{125}$

When applying brand narratives to political marketing a market-oriented party and sales-oriented party should use market research to develop narratives that interest and present the political consumers beliefs, and then attempt to reflect that narrative back to the political consumer, or, as Vincent stated: 'You need to listen to your brand audience through consumer research. Most importantly, you must nurture the culture around your narrative.'126 Vincent further stated that narrative can be important, especially when the consumer / voter is included in that narrative:

\footnotetext{
${ }^{122}$ Vincent, p.58

${ }^{123}$ Vincent, p.58

${ }^{124}$ Howard Gardner (1995) Leading Minds: An Anatomy of Leadership, Basic Books, New York p.49

${ }^{125}$ Gardner, p.43

${ }^{126}$ Vincent, p.289
} 
Arguably, the most important character in your brand narrative is the consumer. Consumers populate the landscape of your brand narrative, but they also integrate your brand as a character or element within their personal narrative, or life movie. A symbiotic relationship exists that requires your understanding because it is a relationship that will be integral to your marketing planning. ${ }^{127}$

Below, I outline Vincent's example of Bill Clinton's use of narrative. First explain what a brand agent is.

\section{Brand agents}

Vincent stated that brand agents can also be used to reinforce sacred beliefs and the brand's narrative. A brand agent can be a 'person, place or thing'. ${ }^{128} \mathrm{~A}$ human brand agent can either be the company's founder and/or CEO, celebrities, spokespeople or fictional characters. ${ }^{129}$ 'Republican and Democrat are Legendary Brands. Candidates are brand agents. And political parties are brand cultures of conflicting, organized social philosophies - or sacred beliefs. Campaigns are story arcs and thematic devices that execute on the narrative foundation.'130

Party leaders have many similarities to a company's founder or CEO, 'these individuals' objectives are most aligned with the objectives of the brand. The brand's success is their fortune. They also provide the brand with authenticity that resonates with consumers.' ${ }^{131}$ A party leader is also tied to the success or failure of the party; if the party fails to get into power then the party leader will have no real political power.

Vincent's work about the role of brand agents and how they work with a brand is useful for my New Labour case study. When looking at the brand of a political

\footnotetext{
${ }^{127}$ Vincent, p. 130

${ }^{128}$ Vincent, p. 234

${ }^{129}$ Vincent, pp.235-237

${ }^{130}$ Vincent, p. 280

${ }^{131}$ Vincent, p.236
} 
party it can be difficult to work out how the party leader fits into the brand. Party leaders can also be considered as a brand on their own, for example, Needham's 2005 article looks at Bill Clinton and Tony Blair as 'brand leaders' and in the case of Blair she focuses more on the leaders rather than the dynamic with the party. ${ }^{132} \mathrm{Also}$, in a parliamentary case the leader is the primary brand agent but other cabinet ministers, members of parliament and other party officials are also brand agents. An MP or a candidate is the party's brand agent for an electorate for example.

Vincent uses Clinton as an example of a politician who used a brand narrative successfully to be elected president in 1992 but failed to transfer this to office once elected. The Clinton brand narrative was described by Vincent as a 'hero's journey.' ${ }^{133}$ Clinton came from a poor upbringing in Arkansas, he met President John F. Kennedy at the White House as a 16 year old then went to Georgetown, Yale and Oxford before entering public service.

Fundamentally, the Clinton campaign was such a success because of the same factors that make Legendary Brands a success: a set of sacred beliefs that resonate strongly with consumers, linked inextricably to an inspirational brand agent. Bill Clinton did not just stand for a worldview. He was the world view. ${ }^{134}$

Clinton was the primary brand agent in this campaign; however, he was not the only agent. Clinton's running mate $\mathrm{Al}$ Gore cancelled out some of his flaws as a candidate, Gore was the son of a respected senator, he was analytical while Clinton was inspiring. ${ }^{135}$

Vincent identified three successful brand narratives that the Clinton campaign used in the 1992. Firstly, Clinton was an ordinary American who worked hard

\footnotetext{
132 Needham, pp343-361

${ }^{133}$ Vincent, p. 284

${ }^{134}$ Vincent, pp.281-282

${ }^{135}$ Vincent, p. 282
} 
and will bring hope to the nation. Secondly, the Clinton presidency brought a generational change to the presidency; Clinton was the first baby boomer president. Thirdly, Clinton had a partnership with Gore, and also Hillary Clinton. This team of smart people were going to Washington to represent the peoples' interest. The Clinton campaign succeeded because:

Sacred beliefs, brand agent, brand narrative were all there, supported by the patriotic symbols and cultural attributes that accompany a presidential campaign. We could construct the road to the White House in a three-act form, or according to the hero's journey. It was a campaign filled with dramatic conflict, each one more challenging to the hero, and each one propelling him forward. It communicated a narrative that supported the personal identity of millions of Americans. Finally, it contained themes that were not only inspirational, but highly relevant. 136

However, once taking office, the President move away 'from the sacred beliefs that gave his campaign its brand foundation.' ${ }^{137}$ The brand agent moved away from the New Democrat brand that Clinton established in the 1992 campaign. In 1994 the Republicans followed the techniques used by Clinton in 1994 with its 'Contract with America.' Newt Gingrich and Dick Armey were the brand agents and were able to successfully win control of Congress in the mid-term elections.

During the introduction and growth stages Clinton was a strong brand agent who represented the brand's values. However, in the later parts of the growth cycle, there was a disconnection between Clinton (the brand agent) and Clinton's New Democrat brand. The brand narrative was well communicated but was not being delivered and maybe rejuvenation was required.

\footnotetext{
${ }^{136}$ Vincent, p.285

${ }^{137}$ Vincent, p.286
} 
Vincent's Legendary Brand work can be applied to the product life-cycle. There is relationship between a brand and a brand agent and at some points the brand agent is stronger than the brand and vice versa.

\section{Figure 2.3 Brand Narratives ${ }^{138}$}

\begin{tabular}{|c|c|c|}
\hline & \multicolumn{2}{|c|}{ Brand Narrative } \\
\hline & Strong & Weak \\
\hline 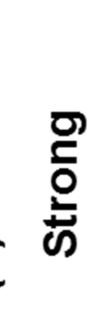 & $\begin{array}{l}\quad \text { Quadrant I } \\
\text { - Symbiotic relationships } \\
\text { - Diversification } \\
\text { - Frequent rejuvenation }\end{array}$ & \begin{tabular}{l}
\multicolumn{1}{c}{ Quadrant II } \\
- Agents possess \\
reasonable market power \\
- Brand narrative drafts off \\
of agent narrative
\end{tabular} \\
\hline$\frac{.}{\mathbb{Z}}$ & $\begin{array}{l}\text { Quadrant III } \\
\text { - Brand narrative sensed } \\
\text { more than demonstrated } \\
\text { - Clues to brand agents } \\
\text { probably rests in culture }\end{array}$ & $\begin{array}{l}\quad \text { Quadrant IV } \\
\text { - Brand narrative may have } \\
\text { aged or outlived } \\
\text { usefulness } \\
\text { - Agents may no longer } \\
\text { resonate with culture }\end{array}$ \\
\hline
\end{tabular}

As illustrated in figure 2.3 above, the strength of the brand and of the brand agent does change. The product life-cycle model suggests that this relationship changes. At some points in the cycle, both the brand agent and the brand itself are strong; at other points they can be week. I test this in my New Labour case study. When for example, New Labour first entered office the brand agent was stronger than the actual party but the brand agent eventually became a liability to the brand.

Kirchheimer and Harrop warned that the leader (brand agent) becoming big or bigger than the brand itself is unfavourable. Kirchheimer argued that the leader should provide enough brand differentiation to make the article plainly

${ }^{138}$ Vincent, p.244 
recognizable, but the degree of differentiation must never be so great as to make the potential customer fear he will be out on a limb. ${ }^{139}$ As Harrop warns:

Yet at the same time the party must avoid becoming identified with its current leader. What passengers want from British Airways is not just that the pilot of this particular flight should be competent but a conviction of the airline's other pilots would have been equally competent had they been crewed for the journey. Similarly with parties, leaders come and go; therefore a reputation for leadership matters as much as the quality of the team. ${ }^{140}$

\subsection{A Product Life-Cycle Approach to Politics}

In the above sections I outlined the models and concepts that I use in developing a product life-cycle model for a political party. The original model as outlined by Kotler and Armstrong is a simple model but to be applied to politics some adjustments need to be made.

For this thesis, I apply the produce life-cycle model to a party parliamentary democracy. Further research is needed to determine whether or not this model can be applied to a candidate-based model with term limits, like the United States of America. In a parliamentary democracy a party could be in power for many generations. It can also regenerate in office by changing leaders during a parliamentary term. For this thesis I focus on a major political party (market leaders and challengers). Potentially this model could also be used for minor parties (followers and nichers).

Instead of using the five steps (product development, introduction, growth, maturity and decline) as outlined by Kotler and Armstrong, I have adopted their model to better fit the political domain.

\footnotetext{
${ }^{139}$ Kirchheimer, p.192

${ }^{140}$ Martin Harrop (1990) "Political Marketing” Parliamentary Affairs, vol.43:3 July, p.279
} 
The 'Introduction' has been changed to 're-introduction' because political parties like the British Labour Party, the British Conservative Party, and the New Zealand National Party are well established parties and have all previously held office in the past. I have also merged the 'product development' and 'reintroduction' phase into one. Unlike a product, a political party does not have the luxury of completely leaving the political market to 'sort' itself out and 'reinvent' itself. The party still has a role to play as the opposition party. For example, during British Labour's 18 years in opposition, between 1979 and 1997, despite all the infighting and policy disagreements during the 1980s, the party still had a reasonable number of seats parliament and was still the official opposition.

Also, in the Kotler and Armstrong model, the product has zero sales during the product development stage, it starts attracting sales during the introductory stage, but it starts from zero. An established political party going through a 'product redevelopment / introduction' stage would not have zero support in the political market. For example, during the 2002 election campaign the opposition New Zealand National Party was attempting to reintroduce itself to the political market with its leader Bill English. The result was one of National's worst election performances in its history, it only won 20.93 per cent of the party vote (compared to 30.50 per cent in 1999). This suggests that even when a political product is at the low point of the cycle (in this case, reintroduction then decline) it still has a number of core supporters who would vote for the party out of loyalty to the party. 
An adapted version of Kotler and Armstrong looks like:

\section{Figure 2.4 Adopted Life-Cycle Model}

\section{Support}

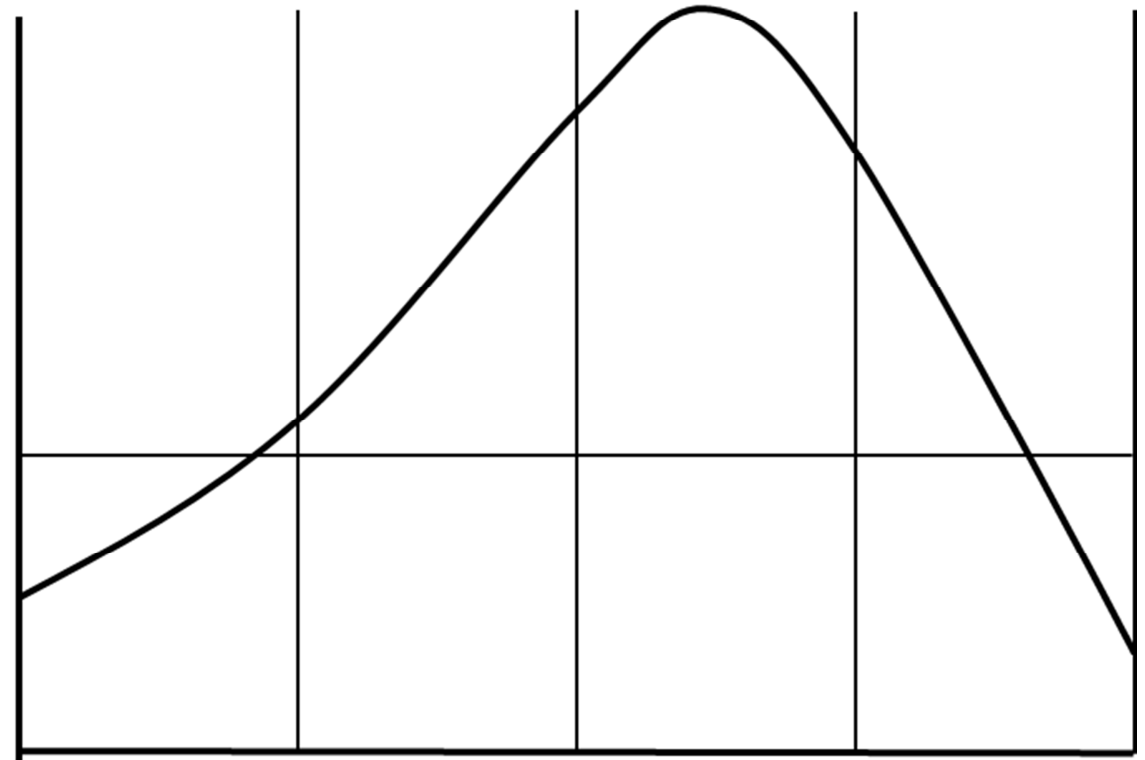

Product Growth Maturity Decline Development /

Introduction

\section{Time}

I changed 'sales' to 'support' because this is appropriate in a political context. Maximised support is what a political party is after, especially through votes on election day, but also through support in opinion polling. I also included a horizontal line which represents the point when the product is in or out of government: above the line represents when the product is in government, below the line when it is not. This is a theoretical model and the time a party spends in each cycle is not be the same; in real life a party may spend five years in the reintroduction stages, three years in the growth stage and eight years in the maturity stage and ten years in decline. 
Figure 2.5 Adapted Product Life-Cycle Model

\begin{tabular}{|c|c|c|c|c|}
\hline & $\begin{array}{l}\text { Product } \\
\text { development / } \\
\text { reintroduction }\end{array}$ & Growth & Maturity & Decline \\
\hline Product & $\begin{array}{l}\text { Market } \\
\text { Orientation } \\
\text { Strong party }\end{array}$ & $\begin{array}{l}\text { Market } \\
\text { Orientation } \\
\text { Strong party }\end{array}$ & $\begin{array}{l}\text { Market } \\
\text { Orientation / } \\
\text { Sales } \\
\text { Orientation } \\
\text { Weakness in } \\
\text { the party }\end{array}$ & $\begin{array}{l}\text { Sales } \\
\text { Orientation / } \\
\text { Product } \\
\text { Orientation } \\
\text { Division in the } \\
\text { party }\end{array}$ \\
\hline Position & Challenger & $\begin{array}{l}\text { Challenger } \\
\text { transitioning } \\
\text { to Market } \\
\text { Leader }\end{array}$ & $\begin{array}{l}\text { Market } \\
\text { Leader }\end{array}$ & $\begin{array}{l}\text { Market } \\
\text { Leader } \\
\text { transitioning } \\
\text { to Challenger }\end{array}$ \\
\hline $\begin{array}{l}\text { Brand } \\
\text { strategy / } \\
\text { narrative }\end{array}$ & Developed & Reinforced & Reposition & Reintroduction \\
\hline Brand agent & Strong & Strong & $\begin{array}{l}\text { Weak } \\
\text { New Brand } \\
\text { agent may be } \\
\text { sought }\end{array}$ & Weak \\
\hline
\end{tabular}

In the product development/reintroduction stage a successful political product's policies is market orientation, the party itself is strong, united and cohesive. In its position as the challenger it aims to take support from other players in the political market, especially the current market leader. At this stage the brand narrative is developed, but like the actual product itself the brand narrative also it is market orientation. The primary brand agent is also strong.

In the growth stage, the political product continues to have a market orientation and the party will be strong. At this point the party gains enough support from 
the previous market leader to become the new market leader. The brand narrative is reinforced and the primary brand agent is tested in office.

In the maturity stage, the product still has a market orientation but also has some sales oriented features and starts to rejuvenate. The party would still be united but there would be some small divisions. The brand narrative also starts to rejuvenate to maintain its position as market leader. The primary brand agent may be weakened from years in office and another brand agent may become the leader of the party.

In the decline phase policies become more sales or product orientated and the divisions within the party occurs. The party loses its position as the market leader and becomes the challenger again.

The following chapters test the assumptions I made in this chapter about a product life-cycle model, using the New Labour case study. The next chapter is a background chapter to the New Labour case study. Chapter four examines New Labour in the product development / re-introduction cycle, chapter five examines the party in the growth stage, chapter six looks at the maturity stage and chapter seven looks at the decline stage. 


\section{3. $\quad$ Failed Labour products (1979-1994)}

This chapter examines the previous Labour products available to the political market before the creation of New Labour in 1994. The purpose is to provide a background to the New Labour case study because the lesson learnt from the failed preceding Labour products shaped the thinking of the creators of New Labour. None of the pre-New Labour products were successful; they moved from the introduction cycle to the decline cycle. They never gained solid support.

Labour's historical support base, the working class, declined in the second half of the twentieth century. In 1964, the working class made up 51 per cent of the electorate. By 1992 it had decreased to 35 per cent. ${ }^{141}$ By 1983 more than half of all working class fathers had non-working class sons. ${ }^{142}$ As the class dynamics changed within Britain, the Labour Party remained the same. Even though there was an 11 per cent decline in the working class, Labour's decline was far greater. Between 1951 and 1983 Labour's support fell by 18 per cent. ${ }^{143}$ The party's resistance to change, which exacerbated party divisions, also contributed to Labour's decline.

Philip Gould's criticism about the effectiveness of previous Labour governments focused on the party's resistance to modernise. He argued that the historical forces that formed the Labour Party, '[f]abianism, trade unionism, religion and a defensive working-class culture - blended to produce a party intrinsically resistant to change.' 144

This chapter is divided into three sections. Section one focuses on the Labour Party under Michael Foot, section two focuses on the Labour Party under Neil Kinnock and, finally, section three looks at the party under John Smith.

\footnotetext{
${ }^{141}$ Patrick Seyd and Paul Whiteley (2002) New Labour's Grassroots: The Transformation of the Labour Party Membership, Palgrave MacMillian, London, p.1

${ }^{142}$ Philip Gould (1998a) The Unfinished Revolution: How the Modernisers Saved the Labour Party, Little, Brown and Company, London p.22

${ }^{143}$ Gould (1998a), p.22

${ }^{144}$ Gould (1998a), p.26
} 


\subsection{Labour under Michael Foot (1980-1983)}

In terms of the product life-cycle, the Labour Party, between 1979 and 1983 was going through a very dramatic decline. In the 1979 election Labour got 36.9 per cent of the vote, which fell to 27.6 per cent in 1983. Even though the party was out of office in this period its behaviour contributed to the party's decline.

For the 1979 and 1983 elections the Labour Party had a product orientation. The policies that the party offered voters was what Labour thought was best for the electorate, regardless of whether the electorate wanted it or not. Using LeesMarshment's comprehensive political marketing approach, the Labour Party was a typical product-oriented party. It offered its product to the electorate because the party thought that the product's merits would sell itself. Labour's defeat in 1979 and 1983 showed, as Lees-Marshment noted, that the politics of conviction no longer seemed a viable approach for a major political party in Britain.'145

\section{Baggage from the previous Labour government}

The 'winter of discontent' was a series of strikes that took place in early 1979. Callaghan's Government tried to control wage levels in order to control inflation, but this was unacceptable to the trade unions. In January 1979 one million people went on strike in reaction to the government. These strikes hurt Labour because it discredited the party's claim that it was the only party that could deal with the trade unions. ${ }^{146}$ The strikes also impacted on the everyday life of ordinary people far more so than an ordinary strike, with food shortages, rubbish piling up on footpaths as well as, school and hospital closures. ${ }^{147}$

Ordinary people were suffering from the strikes and it appeared that Labour could not do anything about it. In the past Labour prided itself on its special relationship with the trade unions, but now the unions were declining in

\footnotetext{
${ }^{145}$ Lees-Marshment (2001a), p.96

${ }^{146}$ William S. Livingston (1981), 'The Conservative Campaign' in Howard R. Penniman (ed.) Britain at the Polls, American Enterprise Institute, Washington, p.117

${ }^{147}$ Livingston (1981), pp.117-118
} 
numbers, becoming more militant and were generally falling out of favour with the public at large. ${ }^{148}$

The 'winter of discontent' damaged Labour's image for a generation, even after the 1992 general election. Focus groups still associated Labour as the party responsible for the 'winter of discontent.'149 Labour also failed to prove itself to be a competent economic manager. ${ }^{150}$

\section{Civil war within the party}

The election defeat allowed brewing divisions within the party to become more open and the party became publically divided. When Labour was in government, the government could get away with ignoring the wishes of conference and the National Executive Committee (NEC) by claiming they are working in the 'national interest' but when the party went into opposition, the extraparliamentary party became more powerful. ${ }^{151}$

While the parliamentary party was coming to terms with the election defeat, members of the radical left had the motivation to shift 'the party policy leftward providing the impetus for changes in the party constitution. As a result of these changes the balance of power between the party's different institutions shifted from the parliamentary party to the extra-parliamentary bodies.' 152

The NEC took charge of the party from the parliamentary party and moved it to the left. ${ }^{153}$ The left also gained control of the trade unions which gave them ultimate policy power at the annual conferences. ${ }^{154}$ Butler and Kavanagh observed that:

\footnotetext{
${ }^{148}$ Seyd and Whiteley, p.3

${ }^{149}$ Gould (1998a), p.5

${ }^{150}$ John Bartle (2002), 'Market Analogies, the Marketing of Labour and the Origins of New Labour' in , O'Shaughnessy, Nicholas J. (ed) Stephen Henneberg (associate ed.) (2002), The Idea of Political Marketing, Praeger, Westport, CT, p.45

${ }^{151}$ David Butler and Dennis Kavanagh (1984) The British General Election of 1983, MacMillan, London, p.47

${ }_{152}$ Butler and Kavanagh (1984), p.3

${ }^{153}$ Butler and Kavanagh (1984), p.45

${ }^{154}$ Bartle (2002), p.49
} 
The years 1979 to 1983 were among the most momentous in the history of the Labour Party. For much of the parliament it was in turmoil. Its constitution was overturned, it elected a new Leader, it split and saw the departure of major right-wing figures, it experienced collapse in support in opinion polls and by-elections. ${ }^{155}$

Groups emerged within the party such as Tony Benn's Campaign for Labour Party Democracy (CLPD) which 'argued that the Parliamentary Party must be made more accountable to the party conference and activists to ensure socialism.' 156 CLPD managed to force some major constitutional changes, such as the election of the party leader by the party as well as MPs, the mandatory reselection of MPs and that the NEC should have control of the manifesto. ${ }^{157}$

The Militant Tendency also emerged; it was a Trotskyite group that followed the ideals of the Russian Revolution and was trying to work within the party. ${ }^{158}$ Despite the efforts of the party hierarchy to expel the 'Militant Tendency,' they managed to maintain their presence in the party, which ultimately scared off voters. ${ }^{159}$

In reaction to the constitutional changes, a group of right-wing moderates within the party broke away to form the Social Democratic Party (SDP). The 'gang of four' that left Labour to form the SDP were former members of previous Labour governments. At first they were determined to fight the left inside the party, but eventually they became more disillusioned. ${ }^{160}$ In the 1983 General Election the SDP and the Liberals formed the Alliance to unite against Labour and the Conservatives. Divisions within the party, however, made it unelectable in the eyes of the electorate.

\footnotetext{
${ }^{155}$ Butler and Kavanagh (1984), pp.63-64

${ }^{156}$ Lees-Marshment (2001a), p.122

${ }^{157}$ Butler and Kavanagh (1984), p.48

${ }^{158}$ Butler and Kavanagh (1984), p.55

${ }^{159}$ Lees-Marshment (2001a), p.122

${ }^{160}$ Butler and Kavanagh (1984), p.69
} 


\section{Policy}

The policy programme that Labour proposed in the 1983 election has been described by Labour Politician, Gerald Kaufman as 'the longest suicide note in history.'161 It proposed:

- substantial Nationalisation;

- greater union influence in economic policy making;

- a non-nuclear defence policy under which it would cancel

Trident and refuse to have cruise missiles stationed in the United Kingdom;

- the two sides of industry and government would decide the nation's economic priorities, including pay;

- any assets privatised by the Conservatives would be renationalised;

- there would be public investment in industry;

- unemployment would be reduced to under a million in 5 years;

- to remove Britain from the EEC;

- to make local authorities buy back any council houses already sold;

- to freeze rents for one year;

- to increase spending on housing by 50 per cent. 162

Labour's promises were not in line with what the electorate actually wanted; for example, despite the promises of nationalisation and withdrawal from the EEC, a 1983 poll showed that only 16 per cent supported Britain leaving the EEC, and that only 18 per cent agreed with a return to nationalisation. ${ }^{163}$

\footnotetext{
${ }^{161}$ Bartle (2002), p.50

${ }^{162}$ Lees-Marshment (2001a), p.124

${ }^{163}$ Lees-Marshment (2001a), p.124
} 
In his autobiography, Tony Blair, who was first elected in 1983, reflected on the state of the Labour Party in 1983. He believed that the party appealed to two sections of society:

From early on, even before my election to Parliament in 1983, I had realised that the Labour problem was self-made and selfinduced. We were not in touch with the modern world. We could basically attract two sorts of people: those who by tradition were Labour, and those who came to a position of support for socialism or social democracy through intellectual progress. Many trade union activists were in the first category; I was a member of the second. 164

In terms of the product life-cycle model, the Labour Party in this period was going through the decline stage. The party was transitioning from being the market leader to the challenger. As discussed above, losing office meant that the extra-parliamentary party gained more power and vented its disappointment about the previous Labour government. The party in this period had no interest in the marketing concept. It was an inward looking party that showed the following characteristics:

- Product Orientation.

- The primary brand agent focused on party unity not the wider political market. Arguably other brand agents, such and Tony Benn, Arthur Scargill and Ken Livingstone, had higher profiles.

- Open divisions within the party.

- Policies appealed to core Labour supporter but not the wider political market.

- Negative baggage from the previous Labour government still lingered.

${ }^{164}$ Tony Blair (2011), A Journey, Arrow Books, London, p.40 


\subsection{Labour under Neil Kinnock (1983-1992)}

After the 1983 defeat, Neil Kinnock was elected party leader. Kinnock and his successor, John Smith, both made fundamental changes to the Labour Party that allowed it to become a sales-oriented party in the late 1980s and early 1990s. These reforms laid the foundations for Blair and his team of modernisers to transform the party. This section looks at the major constitutional, presentation and policy changes that Kinnock made.

\section{Constitutional Changes}

As mentioned above, Labour had historically been the political arm of the trade unions. Labour Party structure was based on the trade union notion of delegatory democracy, where branch members select delegates and these delegates had a mandate to vote as they pleased on issues concerning the party. Kinnock and Smith managed to transform this, so that power would rest with the members of the party instead of the party activists who attained mandates by being elected delegates. Before these reforms the delegates had the power of selecting and reselecting parliamentary candidates, electing the leader and deputy leader and the election of representatives to the NEC. To bypass the dominance of the activists, reforms were set up.

Kinnock faced his first hurdle in 1984 when he proposed a move away from delegatory democracy to a system where the greater membership would have more power. He proposed a system called One Member One Vote (OMOV) where individual party members would be balloted instead of delegates making the decisions, but although this was rejected by the party he managed to make gradual changes. The selection of parliamentary candidates was changed in 1987 with the introduction of partial ballots; constituency members' preferences were taken into account for parliamentary selection and reselection of candidates, but ultimately power resided with delegates. This eventually led to the introduction of OMOV in 1993 by Kinnock's successor John Smith. Also the powers of the unions were decreased in 1993 when unions were denied the power to vote as a 
bloc and instead had to ballot their paid members the same way that constituency members were.

The election of party leader was also reformed. Before 1980 the parliamentary Labour Party elected their leader and deputy leader. The Bennite changes set up an electoral college which consisted of MPs, constituency and trade union delegates, and which was used in the 1983 and 1988 leadership contests. In 1992 constituency delegates were made to ballot individual members on their preferences, but delegates made the final decision. In 1993, the Trade Unions and the constituency delegates were required to ballot their membership and then vote on their behalf. This was first used in 1994 with the election of Blair and John Prescott.

The NEC was also reformed. Previously the seven representatives of constituency parties on the NEC were elected by constituency delegates at the annual conference. Now these posts were elected by individual party members. The membership also increased their power at Conference with their vote being increased from 9 to 30 per cent, at the expense of the Trade Unions.

Kinnock managed to gain some party unity by removing radicals from the party. He managed to persuade people within the party that the presence of extremists risked Labour's electoral success. ${ }^{165}$ The Militant Tendency was expelled and action was taken against a group of radical Liverpool City Councillors. The party took greater control over its membership and by 1992 the NEC had expelled over 100 members. ${ }^{166}$

\section{Presentation Changes}

In December 1985, Philip Gould presented a report that stated that Labour's political communications strategy was poor and needed dramatic changes. He recommended the establishment of the Director of Communications, who would

\footnotetext{
${ }^{165}$ Bartle (2002), p.52

${ }^{166}$ Lees-Marshment (2001a), p.152
} 
primarily focus on the party's communications. ${ }^{167} \mathrm{He}$ also recommended the establishment of a Shadow Communications Agency (SCA), '[i]ts role would be to draft strategy, conduct themes, and provide other communications support as necessary.' The SCA would partake in monthly qualitative research projects, and the SCA would change the Labour Party's image to resemble a 'corporate appearance.'168 The SCA was approved by the NEC in 1986. Peter Mandelson became the first Director of Communications. The SCA undertook some 'minicampaigns,' which were a response to market research.

The SCA did what the Gould strategy intended it to do; it changed the Labour Party's image from amateurish to professional with the adoption of the red rose as Labour's logo. The SCA conducted qualitative research and centralised communications began to become a reality in the Labour Party. Communication became more planned. For example, in July 1991 the party launched their 'Ready for Government' campaign, getting ready for the 1992 general election. Even though no one took it seriously, it did show a shift in the party's campaign organisation. ${ }^{169}$ In the 1987 campaign they tried to counteract the electorate's perceived negatives of Neil Kinnock with the biographical advert Kinnock: the Movie that revealed a softer more compassionate Kinnock. ${ }^{170}$ This showed that the party's communications were better organised than they had been in the past and that it had begun to embrace marketing ideas.

After the 1987 and 1992 elections Gould's research remained the same; Labour was a bitterly divided party, run by extremists, dominated by trade unions, weak on defence and with poor leadership. ${ }^{171}$ Even though the SCA did its best to change Labour's image, it did not manage to convince the electorate. More drastic change was needed.

\footnotetext{
${ }^{167}$ Gould (1998a), p.55

${ }^{168}$ Gould (1998a), p.55

${ }^{169}$ Lees-Marshment (2001a), p.158

${ }^{170}$ Lees-Marshment (2001a), p.158

${ }^{171}$ Gould (1998a), p.87
} 
Even though Kinnock's Labour Party had worked at giving itself a good public image, Kinnock himself had a poor relationship with the media. This was illustrated in the 1987 election where it was 'estimated that 73 per cent of the Sun's election coverage, 54 per cent of the Daily Mail's and 46 per cent of the Daily Star's was 'Labour Knocking." 172 This was repeated five years later when Labour was hammered by the press on the eve of the 1992 General Election. Gould reflected:

The Sun destroyed Neil [Kinnock] and Labour with an eightpage attack entitled "Nightmare on Kinnock street', warning, 'He'll have a new home, you won't' ;'A threat to a proud history', 'My Job will go', 'Prices set to jump', 'Do not trust his judgement or his promises,' and 'Lest we Forget - Hell caused by the last Labour Government.' It delivered the final knock-out blow a day later with its front-page headline: 'If Kinnock wins today will the last person in Britain please turn out the lights'. ${ }^{173}$

The attacks continued with The Mails headline 'Warning: a Labour Government will lead to higher mortgage payments,' ${ }^{174}$ and The Express with 'Can you really afford not to vote Tory?'175 These attacks on Kinnock left their mark on Tony Blair. When he was elected leader in 1994 he went out of his way to woo the Conservative press, primarily owned by Rupert Murdoch.

\section{Policy Changes}

From 1983-87, Kinnock began taming Labour policy from the 1983 manifesto. He managed to reduce the party's objection to the European Community, reduce its calls for public ownership and allow the sale of council houses. ${ }^{176}$ After the 1987 election the party undertook, a major review of policy; first they decided to abandon the party's nuclear policy; secondly, the party decided to move away

\footnotetext{
${ }^{172}$ Gould (1998a), p.77

${ }^{173}$ Gould (1998a), pp.153-154

${ }^{174}$ Gould (1998a), p.154

${ }^{175}$ Gould (1998a), p.154

${ }^{176}$ Seyd and Whiteley, p.5
} 
from protecting unions to protecting the rights of the individual worker, and finally the party declared that it was committed to the market economy.177 Labour's policies before the 1992 election were more mainstream and acceptable to the electorate but, as Lees-Marshment observed, the party was resistant to respond to the findings of market intelligence. ${ }^{178}$

One issue that illustrated this was taxation. When it was revealed to the Shadow Cabinet that 70 per cent of people surveyed believed that they would pay more tax under Labour, the Shadow Chancellor, John Smith, replied that 'he wouldn't be lectured by admen and pollsters.' ${ }^{\text {'179 }}$ The Shadow budget of 1992 confirmed this position with the party's commitment to increase income tax, which was fuel used against the party by the Conservatives in the 1992 election campaign. 180

Even if Kinnock wanted to turn Labour into a Market Oriented Party he would have been unable to do so. As Lees-Marshment observed, even if the leadership knows that the party needs to change to become more electable there needs to be internal support within the party for it. ${ }^{181}$

Labour failed because the electorate still did not trust the party. The voters still remembered the 'Winter of Discontent' and all the divisions within the party, they were also worried about Labour's ability to manage the economy. As market research showed after the 1992 election, people associated the phrases 'union influence,' 'strikes,' 'inflation' and '[Tony]Benn/[Arthur]Scargill'182 with the Labour Party. ${ }^{183}$ Gould noted that even though the Labour Party had changed its communication techniques, it was not enough to outweigh the party's negatives. ${ }^{184}$ Despite Kinnock's changes to the party 67 per cent of respondents

\footnotetext{
${ }^{177}$ Seyd and Whiteley, p.5

${ }^{178}$ Lees-Marshment (2001a), p. 155

${ }^{179}$ Lees-Marshment (2001a), p.150

${ }^{180}$ Lees-Marshment (2001a), p.156

${ }^{181}$ Lees-Marshment (2001a), p.144

${ }^{182}$ Tony Benn is a well know left winger within the Labour party, like wise Arthur Scargill is a well-known left winger within the Labour party as well as a militant trade unionist.

${ }^{183}$ Philip Gould (1998b),,'Why Labour Won,' in Ivor Crewe, Brian Gosschalk and John Bartle (eds), Political

Communication: Why Labour Won the General Election of 1997, Frank Cass, London, p.5

${ }^{184}$ Gould (1998a), p.72
} 
in a 1992 British Electoral Studies survey still considered Labour to be a divided party compared to 28 per cent who perceived the Conservatives to be divided. ${ }^{185}$

Despite Labour's policy review and the moving away from the 1983 manifesto, the electorate still did not want Labour's policies, for as Lees-Marshment noted; 'the Policy Review removed Labour's most apparent weaknesses, but did so without creating any new strengths.'186 One of the major reasons for Labour's 1992 defeat was taxation; Labour ignored the voters' fear that the party was a 'tax and spend' party by proposing tax increases in the 1992 shadow budget. A majority of voters did not want tax increases because they thought this would increase inflation and industrial action. ${ }^{187}$

Kinnock created a new Labour product that was different from the previous Labour product offered in 1983. However, this Labour product failed to win two elections. In terms of the product cycle model, the Labour Party under Kinnock went through the 'product development' and 're-introduction' stage of the cycle. It failed to win enough support to push itself to the growth stage of the cycle. The features of Kinnock's Labour Party include:

- Changes made to the product itself. More power was given to ordinary members and extreme elements of the party were removed.

- Presentation became more professional.

- The primary brand agent was considered weak and received negative press from the Murdoch press.

- There was a policy shift within the party. Policies were tamed compared to the 1983 election.

- The party's brand narrative was still tainted by its past.

- The party failed to win support from the Market Leader to become the Market Leader itself.

\footnotetext{
${ }^{185}$ Lees-Marshment (2001a), p.175

${ }^{186}$ Lees-Marshment (2001a), p.156

${ }^{187}$ Lees-Marshment (2001a), p.156
} 
The Kinnock Labour Party failed to win office in the 1987 and 1992 elections. The party had made changes since the last Labour product, but this product failed to get elected into office.

\subsection{Labour under John Smith (1992-1994)}

The difference between this product and the Foot and Kinnock products discussed above was that it was introduced to the political market, but it was never tested in a general election. Instead this product went into a quick decline after Smith's death.

After the 1992 defeat Kinnock stood down as the party leader and was replaced by his Shadow Chancellor, John Smith. Smith saw little value in the communications changes that were made under Kinnock. He dismantled the SCA and downgraded the importance of communications, so the pace of modernisation slowed down. Smith was popular with the electorate and people were starting to tire of the Conservatives, in a Gallop poll, in 1994, 74 per cent of respondents were unhappy with Major's performance compared to the 34 per cent who were unhappy with Smith's. 188 Smith was a much stronger Primary Brand Agent than Kinnock, but, as stated, this was never tested in a general election due to Smith's death.

Blair viewed the Kinnock and Smith products as an improvement on Labour's earlier ones but ignored the negative brand narrative left by Labour's turbulent recent history:

Under Neil Kinnock and John Smith we had of course broadened, deepened and become more popular, but it felt to me - and more importantly to the public - like a negotiation between us and our past. We were talking in an upbeat way, but there was a tinge of reluctance about it, a reverence for the old days that smacked of denial about how bad it had been. There

${ }^{188}$ Seyd and Whiteley, p.7 
was a care in speaking about the way things were that indicated an uncertainty, a lack of thorough conviction about the way things would be in the future. ${ }^{189}$

In terms of the product life-cycle, the Labour Party product presented by John Smith was only developed and introduced into the political market. However, because of Smith's death, the product was never fully introduced into the market, nor fully tested.

${ }^{189}$ Blair (2011), p.84 


\section{Product Development and Re-Introduction}

This chapter applies the product life-cycle model to New Labour and focuses on the product development of New Labour and its reintroduction into the political market. For the purpose of this thesis, I have identified this phase as being between 1994, when Blair became leader of the Labour Party, and April 1997, a month before New Labour was elected to office. The election campaign of 1997 gave New Labour the momentum to move into the 'growth' phase of the product life-cycle model.

The previous chapter documented that Labour was considered unelectable between 1979 and 1992. By 1997 the party under Tony Blair managed to defeat the Conservatives in a landslide. Crewe observed that:

No party leader in modern British history prepared his party for an election with as thought-through, coherent and radical an electoral strategy as Tony Blair did between his becoming leader in 1994 and the general election three years later. No party leader in modern times has attempted, let alone succeeded, in persuading a reluctant party to abandon long-established policies and structures for the sake of electoral victory. After four successive election defeats, the acute disappointment of 1992 and eighteen years in opposition, a desperate party was ready to respond. 190

As outlined in chapter three, the Labour Party in the 1980s and early 1990s was unelectable. By 1992 the negative attributes that had haunted Labour in the 1980s were still attached to the party. Market research conducted after the 1992 election show that the party was still judged by its past, people associated

\footnotetext{
${ }^{190}$ Ivor Crewe (2001) 'Elections and Public Opinion' in Anthony Seldon (ed.) (2002) The Blair Effect, Little Brown, London, p.67
} 
phrases like, 'winter of discontent,' 'union influence,' 'strikes,' 'inflation,' 'disarmament,' and 'miners' strike/three day week' with the party. ${ }^{191}$

People thought 'Labour's values are negative, aimed at depriving people of: wealth, in the form of taxes, choice in education and health, and ownership, in the form of council houses.' ${ }^{192}$ Likewise people saw Labour as being hostile to 'People who have money/savings/even pensions, people who want to start their own business: and people who want the best for their kids.'193 People were saying that 'I've left the Labour Party and the Labour Party has left me.' And, 'it's obvious isn't it: the better you are doing, the more money you have got, the more likely you are to vote Tory. It's hardly surprising.'194

As outlined in chapter two, I have altered the product life-cycle model into four different parts, product, strategy, brand narrative and brand agent. In this chapter I look at the product development and re-introduction from these parts. I also look at the support for New Labour during this time. Before getting into the case study I discuss the influence that the Democrats in the United States had on the creation of New Labour. The modernisers created New Labour by learning the lessons from Labour's failures in the 1980s and early 1990s (as outlined in the last chapter); the success of the Democrats in 1992 gave the modernisers a road map of how to be electorally successful.

\subsection{Democrats influence on New Labour}

As part of the product development of New Labour, the modernisers used techniques and lessons from the Democrats in the United States under Bill Clinton. Seldon argued that Blair's trips to the United States in 1991-1993 were a turning point for him because it showed him and Brown that Labour needed to attract middle-ground voters to win and the Clinton campaign in 1992 gave

\footnotetext{
${ }^{191}$ Lees-Marshment (2001a), p.183

${ }^{192}$ Lees-Marshment (2001a), p.183

${ }^{193}$ Lees-Marshment (2001a), p.183

${ }^{194}$ Lees-Marshment (2001a), p.183
} 
them a road map for how to achieve this.'195 Philip Gould also forged links with the Democrats and worked with the Clinton campaign during the 1992 election.

In January 1993, Brown and Blair went to Washington and met with key figures from the Clinton team, pollster Stan Greenberg, President of the Democratic Leadership Council (DLC) Al From, and Elaine Kamarck from the Progressive Policy Institute (PPI). Seldon noted that the DLC and the PPI had been credited for repositioning the Democrats so it was in tune with mainstream America. ${ }^{196}$ Karmack recalled:

I was invited with $\mathrm{Al}$ and Stan to the British Embassy to meet Tony Blair for tea. We had no idea who he was....Tony Blair looked like a kid to us. He took out a small notebook and asked us some question about how we begun in 1989 and we talked him all the way through it. He took furious notes about everything we said. He was very courteous, very humble, very focused. 197

In 1989 the Democrats were in a similar situation as Labour, they were perceived as being the party of 'tax and spend' policies; it was perceived as weak on defence and soft on law and order and had not won a presidential election since 1976. The main lesson that New Labour learnt from the Democrats was to identify the issues that the governing party was strong on and then develop a plan to become strong on those issues. For New Labour these issues included economic credibility, law and order and patriotism. ${ }^{198}$

On a practical level, Gould attained the idea of moving the campaign to a central office space or 'war room' from the Clinton campaign in 1992 because he noticed

\footnotetext{
195 Anthony Seldon (2004), Blair, p.125

196 Seldon (2004), p.122

${ }^{197}$ Quoted in Seldon (2004), pp.122-123

198 Andrew Gamble (2010), 'New Labour and Political Change,' Parliamentary Affairs, vol.63:4 p.643
} 
that a concentrated open-plan office floor would be better for campaigning rather than people running down corridors to different offices. ${ }^{199}$

\subsection{Product}

This section examines the Labour party product and is divided into two parts. Firstly, I outline the policy products that New Labour offered. These policies were market-oriented and reflected the political consumer. Secondly, I look at the actual Labour Party itself. During this phase of the product life-cycle model the party became more centralised giving the leadership more scope to pursue market-oriented policies

\section{Market-Orientation of policy}

One way New Labour showed that it had developed more market-oriented policies was through the use of pledges and pledge cards. According to Gould, the pledges were developed over a long period of time following meetings with colleagues and focus groups. ${ }^{200}$ These pledges reflected the concerns of the voters addressing education, law and order, health, youth unemployment and the economy. Gould reflected that:

The pledges worked better than anything else I have ever tested in politics.... They worked because they connected immediately to people's lives; because they were relatively small, which gave them credibility; because they were costed; and because they were an explicit contract between the voter and Tony Blair. The fact that it was he who made the promise, he who offered the contract, added enormously to their power. ${ }^{201}$

Gould stated that a lot of market research went into developing the pledges, but this research was important because in the past Labour had always offered

\footnotetext{
199 Gould (1998a), p.299

${ }^{200}$ Philip Gould (2011) The Unfinished Revolution: How New Labour Changed British Politics For Ever, Abacus, London, p.262

${ }^{201}$ Gould (2011), p.265
} 
better schools and hospitals and this was not believed. ${ }^{202}$ However, these pledges were more concrete and were costed and 'presented in the form of an accountable contract.'203

The pledges were:

- 'We will cut class sizes to 30 or under for five-, six- and sevenyear-olds by using money from the assisted places scheme.'

- 'We will introduce a fast-track punishment for persistent young offenders by halving the time from arrest to sentencing.'

- 'We will cut NHS waiting lists by treating an extra 100,000 patients as a first step by releasing $£ 100$ million saved from NHS red tape.'

- 'We will get 250,000 under-25-year-olds off benefit and into work by using money from a windfall levy on the privatised utilities.'

- 'We will set tough rules for government spending and borrowing and ensure low inflation and strengthen the economy so that interest rates are as low as possible to make all families better off.'204

These pledges were placed onto a credit card sized card. The idea was borrowed from California which was used for a state-wide referendum on healthcare, the back of that card stated the benefits of voting yes in the referendum. The Labour card contained the words: 'Keep this card, and see that we kept our promises. ${ }^{205}$

At this stage of the product life-cycle, great care was taken to develop marketoriented policies that reflected the concerns of the political market. These policies were also costed and showed political consumers that these policies were achievable.

\footnotetext{
${ }^{202}$ Gould (2011), p.266

${ }^{203}$ Gould (2011),p.266

${ }^{204}$ Lees-Marshment (2009), p.201

${ }^{205}$ Gould (1998a), p.271
} 


\section{Centralisation of the party}

The leadership of New Labour built upon changes to the party structure made by Kinnock and Smith. The leadership increased its power at the expense of party activists and the trade unions. They did this, as previously discussed, by increasing the power of the individual party membership; this has 'marginalis[ed] representative procedures inside the party, introducing plebiscitarian techniques, going over the heads of the party conference and the activist layer in favour of widespread membership ballots. ${ }^{206}$ Seyd and Whiteley argued that New Labour fits in a plebiscitary model where the party "has an organization and a membership, but the leaders concentrate power in their own hands and the role of the members is to endorse periodically fairly general policy statements and to legitimize whatever the leadership wants to do.'207

New Labour had become a more leader-centred plebiscitary party. The movement to a plebiscitary party gave the Labour leadership more flexibility and the opportunity to develop market-oriented policies. Since the leadership can determine policy it can easily respond to the needs of the electorate and offer the electorate a programme that suits them. A plebiscitary model suits the leadership, but Seyd and Whiteley warned, the leader can become too powerful and if there is no party mechanism to question the leader then he/she can get too corrupted by power as was the case with Margaret Thatcher in the late 1980s. ${ }^{208}$

I have identified three features of the New Labour's plebiscitary model:

Membership and recruitment drive - money was spent on marketing the party through broachers, newspapers and magazines. ${ }^{209}$ Initially this drive was successful, at the ' 1995 conference it was reported that 100,000 people had joined

\footnotetext{
${ }^{206}$ Eric Shaw (2002) 'New Labour in Britain: New Democratic Centralism,' West European Politics, vol.25:3, pp.147-148

${ }^{207}$ Seyd and Whiteley, p.168

${ }^{208}$ Seyd and Whiteley, p.17

${ }^{209}$ Meg Russell (2005), Building New Labour: The Politics of Party Organisation, Palgrave Macmillan, London, p.220
} 
in the previous year.'210 Widen Labour's membership added more moderate and mainstream view to the party removing influence from trade unionists and activists. $^{211}$ The recruitment drive also suggested that New Labour needed members to legitimise the decisions already decided by the leadership. ${ }^{212}$

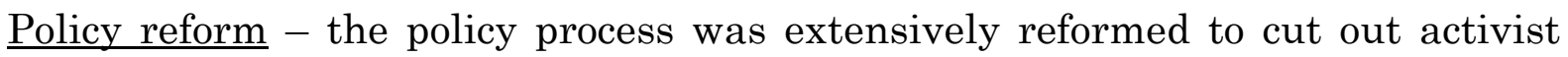
members and strengthen the leadership. The leadership of the party was highly critical of the party's traditional policy making process through the party conferences; they argued that the policy making process only included a few conference delegates, therefore did not represent the views of the party as a whole. ${ }^{213}$ The policy that was produced was poor and failed to see the big picture of complex issues; also, the policy making process was divisive and arguing about policy openly in public damaged the party's image. ${ }^{214}$ During the 1997 election, manifestos were sent to party members for their endorsement, the members could either say yes or no, but could not propose changes to the manifesto.

Unity from Labour MPs and candidates - New Labour MPs and candidates were well behaved and united. Labour MP Helen Liddell said that 'the discipline that was imposed on the party by the leadership in the period 1994-97 was formidable...shadow ministers and backbench MPs equally had to be consistently 'on message."215 Likewise Butler and Kavanagh observed that the party put up with Blair's personal style of leadership because they knew that disunity would spoil the party's chances in the election. ${ }^{216}$

Lees-Marshment argued that even though Blair was taking a market-oriented approach to the general electorate, he was taking a product-orientated approach to the party membership. ${ }^{217}$ This was a necessary strategy considering the

\footnotetext{
${ }^{210}$ Russell, p. 220

${ }^{211}$ Russell, p.267

212 Seyd and Whiteley, p.173

${ }^{213}$ Shaw, p. 148

${ }^{214}$ Shaw, p.148

${ }^{215}$ Quoted in Seldon (2004) p.248

${ }^{216}$ David Butler and Dennis Kavanagh (1997) The British General Election of 1997, MacMillan, London p.54

${ }^{217}$ Lees-Marshment (2001a), p.189
} 
history of Labour, a market-oriented approach might have exacerbated divisions within the party. Lees-Marshment also observed that New Labour, 'alienated traditional supporters and critiques contend it has lost its ideology and beliefs and stands for nothing....Blair did not give much attention to adjusting the product to suit internal support.'218 However, Blair knew that traditional supporters would always buy Labour's product, Labour could neglect responding to their views and still achieve electoral success. ${ }^{219}$

At this stage of the product life-cycle, the modernisers made changes to the Labour Party structure making it more centralised and limiting the power of activists and the trade unions. Centralising power allowed the leadership more flexibility to adopt and implement more market-oriented policies; this is a similar approach to Kirchheimer's catch-all party that needed to be flexible to catch a large group of voters rather than a loyal membership. ${ }^{220}$ Also, this move showed the political market that the party had moved on from its historical perception that its controlled by trade unions and activist.

\subsection{Positioning}

In this section I discuss how New Labour behaved as the challenger and what it did to position itself as the market leader, to replace the incumbent Conservative government. At what point does a party become the market leader and the challenger? New Labour was leading the Conservatives in the polls in the lead up to the 1997 election; did this make Labour the market leader? For this thesis, I argue that even though New Labour did have the support of the political market, because it did not have a majority in Parliament to influence policy, nor did have the authority of government; it was still the challenger. Opinion polling is a good indication of how people are going to vote and how the political market feels about the parties at a given point of time. However, the result of a general election carries more weight because it delivers the market-leader real power to deliver policies. Rawnsley also noted that during the 1980s there were times

\footnotetext{
${ }^{218}$ Lees-Marshment (2001a), p.181

${ }^{219}$ Lees-Marshment (2001a), p.181

${ }^{220}$ Kirchheimer, p.193
} 
where old Labour under Foot and Kinnock had large leads over Thatcher in opinion polling but this support was fickle and never translated into seats in Parliament. ${ }^{221}$

As the challenger, New Labour focused on taking support away from the market leader. Firstly, I look at the state of the market leader at this point in time. Secondly, I examine what New Labour did to take ground from the market leader.

\section{The Market Leader (Conservative Party - 1994-1997)}

While New Labour was going through the product development and reintroduction phase of the product life-cycle model, the Conservatives were going through a decline phase. In summary:

- The Conservatives lost its reputation as being economically competent when Britain was ejected from the European Exchange Rate Mechanism in 1992.

- There was division within the party over the country's relationship with the European Union.

- Conservative MPs were tainted by scandal and sleaze.

- There was a call for a change in government, the Labour Party was ahead and maintained a lead in the polls.

\footnotetext{
${ }^{221}$ Andrew Rawnsley (2013) 'The Conservatives are plotting and talking themselves to death, Guardian Website, Accessed 13 February 2014, <www.guardian.co.uk/commentisfree/2013/mar/17/tories-not-in-hell-butcan-put-themselves-there>
} 
Figure 4.1 Satisfaction of John Major's Conservative Government 1992-1997222

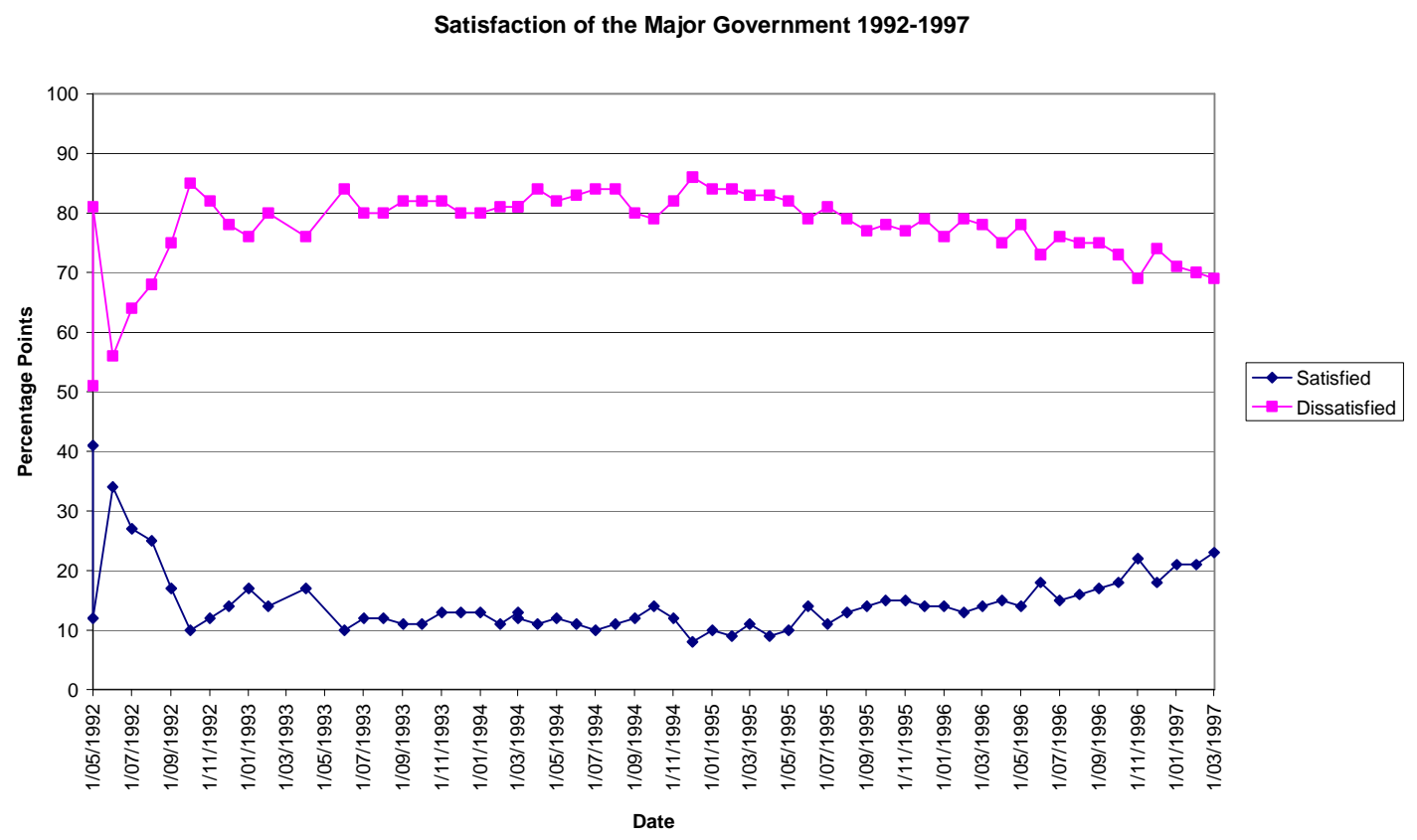

Figure 4.1 shows, satisfaction for John Major's government was low. After the 1992 election satisfaction reached 42 per cent, but after the EMR crisis, satisfaction remained low, and dissatisfaction grew. The low point was reached in December 1994, during the honeymoon of Blair's arrival as Labour leader, where satisfaction with Major's government was eight per cent and dissatisfaction was 86 per cent.

\section{New Labour as the Challenger}

Butler and Collins state that the strategies of a challenger are to 'target the market leader directly in a high-risk but potentially high-payoff strategy, attack competitors of its own size, or attack small local regional competitors.' ${ }^{223}$ I have identified three strategic moves that New Labour made as the challenger. The aim of New Labour at this point in time was to become the market leader and they did this by challenging the Conservatives head-on by attracting the centre voters that had voted for them. Firstly, New Labour accepted the consensus

\footnotetext{
${ }^{222}$ Ipsos MORI, 'Political Monitor Satisfaction Ratings 1988-1997' (1997), Ipsos Mori Website, Accessed 23 March 2013, <www.ipsosmori.com/researchpublications/researcharchive/poll.aspx?oItemID=2438\&view=wide> ${ }^{223}$ Collins and Butler (2002), p.9
} 
established by the market leader. Secondly, New Labour positioned itself as being strong in areas that the Conservatives were traditionally strong in. Finally, the party modernised the way it responded to the media.

\section{Accepting the market leader}

New Labour accepted the market leader's stance on issues such as privatisation, the free market and crime and move onto new battles were New Labour could frame the debate. ${ }^{224}$ Blair was determined to show that New Labour had moved on from the Labour of the past and made it clear that there would be 'no return to old union laws; no renationalisation of the private utilities; no raising of the top rate of tax; no unilateralism; no abolition of grammar schools.'225

Blair did this by accepting some of the changes that Margaret Thatcher made as Prime Minister in the 1980s. Blair stated that by acknowledging and supporting the changes that Margaret Thatcher had made would appeal to those who voted for the Conservatives in that era. Blair wrote: 'I knew the credibility of the whole New Labour project rested on accepting that much of what [Thatcher] wanted to do in the 1980s was inevitable, a consequence not of ideology but of social and economic change.' He argued that Thatcher was ideological, however. 'Britain needed the industrial and economic reforms of the Thatcher period.'226 Thatcher returned the compliment by saying ' $\mathrm{I}$ see a lot of socialism [in Labour] but not in Mr Blair. I think he genuinely has moved.'227

\section{Taking ground from the market leader}

Gould identified this strategic position as both taking the Conservative's ground and taking back ground that Labour had lost when New Labour presenting itself as the party of business, family, responsibility, enterprise, and aspiration. ${ }^{228}$ The party accepted the findings of its market research; it accepted new positions on issues that they had been traditionally weak on.

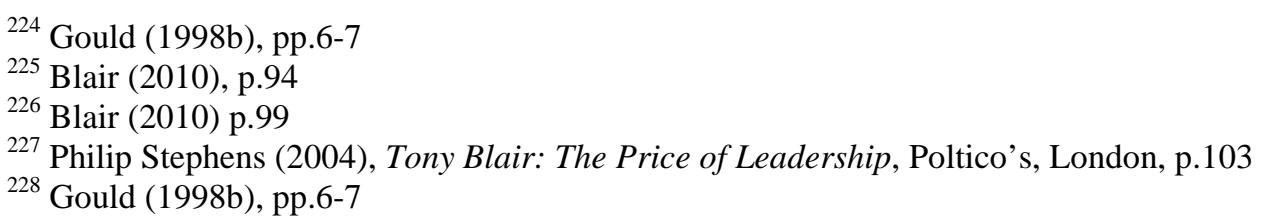


New Labour established itself as a party that embraced the market, it had shown this by abolishing clause four of its constitution (discussed below) and making policy commitments in its manifesto like 'We will provide stable economic growth with low inflation, and promote dynamic and competitive business and industry at home and abroad.'229 This would neutralise any Conservative attack that accused Labour of being traditional Labour socialists. Voters also perceived Labour as a tax and spend party. New Labour cancelled this out by stating that it will not increase taxes and attacking the Conservatives for their twenty-two tax rises. ${ }^{230}$

In July, 1995, 35 per cent surveyed stated that they preferred New Labour's policies on the economy to 20 per cent who preferred the Conservative's. By April, 1997, 44 per cent preferred Labour to 29 per cent who preferred the Conservative. ${ }^{231}$ This showed that New Labour was able to maintain its lead on the economy to the lead up to the 1997 election. New Labour also took on the Conservatives in traditional areas of strength such as law and order. The Labour Manifesto advocated a tougher stance of crime, being 'tough on crime and tough on the causes of crime.'232 Labour stated that under the Conservative government, crime had doubled, the manifesto stated that Labour would insist on individual responsibility for crime, and will attack the causes of crime by measures to relieve social deprivation.'233

As Gould noted, New Labour's repositioning re-established Labour's links with the electorate; he stated that 'most people believe in punishment, they believe in right and wrong, they believe in discipline and order. That for so long Labour denied this, that they sought to excuse the inexcusable on grounds of education,

\footnotetext{
229 'Labour Party Manifesto, General Election 1997,' Accessed 1 December 2005 <www.psr.keele.ac.uk/area/uk/man/lab97.htm>

${ }^{230}$ Quoted from Gould (1998a), p.285

${ }^{231}$ Ipsos MORI Political and Social Trends, Ipsos Mori Website, Accessed 16 February 2013, <www.ipsosmori.com/researchspecialisms/socialresearch/specareas/politics/trends.aspx>

232 'Labour Party Manifesto, General Election 1997'

233 'Labour Party Manifesto, General Election 1997'
} 
class or other disadvantages. ${ }^{234}$ Gould stated that Blair's speech was common sense and had a huge impact within the electorate. ${ }^{235}$ This stance was reflected in the rhetoric of the 1997 manifesto: 'On crime, we believe in personal responsibility and in punishing crime, but also tackling its underlying causes so, tough on crime, tough on the causes of crime, different from the Labour approach of the past and the Tory policy of today. ${ }^{2} 36$

In July 1995, 33 per cent of people polled thought that New Labour had the best policies for law and order, compared to 25 per cent who thought the Conservatives were better. By April 1997, 30 per cent thought Labour's policies were best compared to 32 per cent who preferred the Conservatives. ${ }^{237}$ Even though the poll suggested that the Conservatives had a better policy on law and order, New Labour had neutralised the issue.

\section{Working with the media}

Gould identified that working with the media was another strategic way to become the market leader. 'Broadcasting news has its own agenda and it is pointless fighting it. Shape the agenda certainly, but also exploit the agenda that is in place. ${ }^{238}$ To work with the news, the party moved its headquarters to Millbank Towers. Here the party set up a professional campaigning organisation based on Bill Clinton's 'war room' in the 1992 campaign. The purpose of Millbank Tower was to be a media centre which 'was open 24 hours a day, showcasing such new propaganda delights as the 24-hour rebuttal units. 'Pre-buttals', another idea from the Clinton team, were also arranged. Campaigners were linked: pagers, the internet and faxes helped keep its candidates 'on message." 239

\footnotetext{
${ }^{234}$ Gould (1998a), p.188-189

235 Gould (1998a), p.189

236 'Labour Party Manifesto, General Election 1997,' Accessed 1 December 2005 <www.psr.keele.ac.uk/area/uk/man/lab97.htm>

${ }^{237}$ Ipsos MORI Political and Social Trends, Ipsos Mori Website, Accessed 16 February 2013, <www.ipsosmori.com/researchspecialisms/socialresearch/specareas/politics/trends.aspx>

${ }^{238}$ Philip Gould (1998b), pp.6-7

${ }^{239}$ Nicolas O'Shaughnessy (2003), 'The Symbolic State: A British Experience,' Journal of Public Affairs, vol3:4, p.306
} 
The computerised Excalibur system contained 'documents, speeches, statistics and press cuttings' which could be accessed easily. 240

Blair also made great effort to get Newscorp's Rupert Murdoch on his side. Murdoch's newspapers had traditionally supported the Conservatives, Blair was invited to make the keynote speech at Newscorp's 1995 conference on Hayman Island. Powell argued that 'Murdoch likes to back the winning side, and he could read the opinion polls as well as anyone else, and so in the course of that year into 1996 a number of his titles shifted in favour of New Labour. Tony put great efforts into maintaining the relationship right through his time in government and thereafter. It paid off. ${ }^{241}$

In this stage of the product life-cycle model the New Labour was the challenger. To become the market-leader it directly took on the current market-leader, the Conservatives, by arguing that New Labour was as strong or stronger in policy areas that the Conservative Party was traditionally strong in. This was an attempt by New Labour to take the centre ground and gain support from voters who voted Conservative in the previous election. It also professionalised its media operation with the creation of a rapid rebuttal media.

\subsection{Brand narrative}

The New Labour brand narrative focused around the idea that it was new and was different to the party of the past.

According to Rajagopal and Sanchez at this point of the product life-cycle the brand is being developed. ${ }^{242}$ However, in the case of New Labour the brand and narrative was developed early in 1994 and 1995, and from 1996 the focus of the brand's narrative was to reassure people that New Labour had actually changed.

\footnotetext{
${ }^{240}$ O’Shaughnessy (2003), p.306

${ }^{241}$ Jonathan Powell (2010), The New Machiavelli: How to Wield Power in the Modern World, Vintage Books, London p. 190

${ }^{242}$ Rajagopal and Sanchez, pp.243-244
} 
This brand narrative was emphasised with symbolic changes to the party structure and a narrative built around the primary brand agent Tony Blair, and is similar to the narrative that Vincent identified for Bill Clinton - the selfless hero who transformed Labour and brought it to power. As part of the narrative, effort was made to reassure voters that there was little risk voting for New Labour.

As part of its brand narrative that New Labour is new, it also presented a positive vision of the future and that the party was above traditional bipartisan politics. In a speech Blair said that 'New Labour is neither old left or new right. We understand and welcome the new global market. We reject go-it-alone policies on inflation and the macro-economy. We stand for a new partnership between government and industry. ${ }^{243}$ New Labour was inclusive of all people when Blair said:

Let's build a new and young country that can lay aside the old prejudices that dominated our land for generations. A nation for all the people, built by the people, where old divisions are cast out. A new spirit in the nation based on working together, unity, solidarity, partnership. ${ }^{244}$

This showed that New Labour had not only moved on from old Labour and what was holding it back in the past. New Labour's also attached itself to the 'Cool Britannia' wave that was sweeping through Britain in the mid-1990s. During this period there was increased pride in British pop culture with bands such as the Spice Girls, Oasis, Supergrass and Blur. Blair associated New Labour to this movement by using a 'Britpop' song 'Things can only get better' by D:Ream as its campaign song.

\footnotetext{
${ }^{243}$ Quoted from Gould (1998a), p.237

${ }^{244}$ Gould (2011), p.247
} 
As Vincent stated in his brand narrative work, a successful brand narrative must reflect the culture of the audience and New Labour does this. The brand narrative that New Labour portrayed at this time was it was a new product, it was different to the previous Labour products and it was different to the incumbent Conservative Government. This narrative was reinforced by:

- A leader who personifies the values of the brand.

- A symbolic battles with the party.

- Policies that reflect the political market.

- Reassurance that the brand will deliver

Below I outline examples of how New Labour used the above tactics to reinforce its brand narrative.

\section{Leader that personifies the brand}

Tony Blair personified the New Labour brand, at the beginning of his leadership focus groups liked 'his charisma, his message of pulling together, and the sense of a new kind of politics and a new politician. ${ }^{245}$ Blair's personal narrative was similar to the 'hero's story,' Gould recalled when he first met Blair that he had 'a sense of the destiny of the nation, and of the pulse of the people'246 Blair did not have the traditional background of a Labour politician, he was not involved with the unions and was a barrister. He became leader after John Smith's death and reformed and challenged the trade unions, and changed the party to bring change to the country. Compared to John Major and the Conservatives, Blair was a younger and far more charismatic politician; he did not have any political baggage. He managed to bring unity to the party and lead them to victory in the 1997 election.

\footnotetext{
${ }^{245}$ Gould (2011),p.199

${ }^{246}$ Gould (2011),p. 188
} 
Symbolic battles with the party

New Labour used pseudo-events, such as the battle with the party to remove clause four of the party's constitution to reinforce the brand narrative that the party had changed. Pseudo-events are created events that are made to be reported on by the media, they are not 'spontaneous, but comes about because someone has planned, planted, or incited it.'247

The modernisers believed that "without high-profile internal battles [which are reported in the media] the public simply would not notice reform.'248 Similarly Gould argued that real events, such as the removal of clause four and the balloting of the manifesto create 'real tension, genuine uncertainty: that is what is necessary to persuade a modern voter.'249

The removal of clause four was an important and symbolic change that showed that New Labour was making a real shift from its past. The clause was a commitment to socialism and nationalisation and its removal was one of Blair's first major acts as leader in 1994. The original clause was a socialist commitment for nationalisation that originated in the party's 1918 constitution. Clause four stated that the party aimed:

To secure for the workers by hand or by brain the full fruits of their industry and the most equitable distribution thereof that may be possible, upon these basis of the common ownership of the means of production, distribution, and exchange, and the best obtainable system of popular administration and control of each industry and service. ${ }^{250}$

Even though the clause had not been followed by the party for some time, people in the party saw it as 'an emblem of an earlier idealism, a status it shared with

\footnotetext{
${ }^{247}$ Daniel Boorstin (1987) The Image: A Guide to Pseudo-Events in America, Vintage Books, New York, p.11

${ }^{248}$ Russell, p.252

${ }^{249}$ Gould (1998b), pp.6-7

${ }^{250}$ Quoted in David Coates(2000) 'The Character of New Labour,' in David Coates and Peter Lawler (eds.) New Labour in Power, Manchester University Press, Manchester p.4
} 
the party's commitment to equality - once again an unattainable goal but a cherished ideal.'251 However, Mandelson believed that 'It prevented the party from proclaiming clearly what it did stand for, and it confused the voters about Labour's intentions.' ${ }^{252}$

At the 1994 party conference Blair, with the support of key shadow cabinet members, proposed the abolition of clause four. When it came to the vote the party rejected the proposal 50.9 per cent to 49.1 per cent. ${ }^{253}$ Blair approached the NEC, which agreed to hold a special conference in early 1995. ${ }^{254}$ By going over the heads of activists and trade unions Blair appealed to the party membership directly. ${ }^{255}$ The campaign gave Blair an opportunity to meet his party, he showed his calm relaxed style of leadership, which only his Sedgefield constituents had seen before, and he realised that Labour voters throughout Britain were like his constituents. $^{256}$ The special conference in April 1995 passed the new clause four stated that:

The Labour Party is a democratic socialist party. It believes that by the strength of our common endeavour we achieve more than we achieve alone, so as to create for each of us the means to realise our true potential and for all of us a community in which power, wealth and opportunity are in the hands of the many, not the few, where the rights we enjoy reflect the duties we owe, and where we live together, freely, in a spirit of solidarity, tolerance and respect. ${ }^{257}$

The campaign to remove clause four allowed Blair to meet his party and show his party what kind of leader he was, but more importantly, clause four showed that Blair was prepared to ballot members of the party to overcome objections

\footnotetext{
${ }^{251}$ Philip Stephens (2004) Tony Blair: The Price of Leadership, Poltico's, London p.90

${ }^{252}$ Quoted from Stephens (2004), p.90

${ }^{253}$ Seldon (2004), p.223

${ }^{254}$ Seldon (2004), p. 224

${ }^{255}$ David Butler and Dennis Kavanagh (1997) The British General Election of 1997, MacMillan, London p.51

${ }^{256}$ Seldon (2004), p. 225

${ }^{257}$ Quoted from Blair (2010), pp.86-87
} 
from the unions and party activists. The campaign and change was widely reported on and showed people that New Labour was making real changes. It also showed that Blair was determined to change the party, he even threaten to resign if the party did not abolish the clause because he would argue that the party was not serious about change. ${ }^{258}$ I call the removal of clause four a pseudoevent because even though the constitutional change was important, the reporting of the event was more significant.

Another significant pseudo-event that New Labour used was taking the manifesto to the party and balloting members to endorse it. This event showed voters that the New Labour project had the support of the party. 259 This event also helped 'break through the wall of cynicism surrounding the voters. They were not impressed by words alone, they wanted actions and preferably actions involving conflict and opposition. Only then would they believe something had actually happened.'260

\section{$\underline{\text { Reassurance }}$}

During this period New Labour constantly reassured voters that it had changed and that it had modernised and had actually changed. Greenberg's focus groups observed that 'change voters' were dissatisfied with the Conservatives and it was New Labour's task to ensure that a vote for Labour was an easy and 'safe' choice. ${ }^{261}$

Gould identified 1996 as the year that New Labour needed to gain the voters' trust - they had modernised the party in 1995, but needed to reinforce the brand narrative through 1996 until the general election. ${ }^{262}$ By the end of 1995 New Labour was defined by voters as Blair's 'willingness to take on the unions. ${ }^{263}$ ' Research found that voters still did not believe that New Labour on taxes, 42 per

\footnotetext{
${ }^{258}$ Butler and Kavanagh (1997), p.51

${ }^{259}$ Gould (2011), p.258

${ }^{260}$ Gould (2011), p.258

${ }^{261}$ Quoted in Gould (1998a), p.251

${ }^{262}$ Gould (2011), p.252

${ }^{263}$ Gould (2011), p.253
} 
cent of people surveyed believed that the party would raise taxes. ${ }^{264}$ Others believed that one of the problems with old Labour was that it did not address issues that affected ordinary people, instead it focused on issues like 'homosexuals, immigrants, feminists, lesbians, boroughs putting their money into peculiar things.'265

Blair wrote that he was obsessed with reassurance and that between 1995 and 1997 he: 'was in a perpetual motion of reassurance. The more the poll lead went up, the more I did it. Members of the Shadow Cabinet would frequently say: Come on, enough, we are miles ahead. Each time they said it, I would get hyperanxious, determined not for a single instant to stop the modernising drive....Reconnection was great and policy change was essential, but above all, people need to know that when I was tested, I would stay true to the modernising appeal.'266

\section{Policies that reflect the brand and the political market}

As stated in earlier discussions about the product and positioning, New Labour's policies reflected the narrative that New Labour was different from old Labour. As well as proposing policies Blair took a different approach in the media when questioned about the economy. For example in September 1994, when interest rates were increased by 0.5 per cent, Blair moved away from the standard Labour response of criticising the Chancellor's decision. Instead Blair told the Financial Times that 'inflation is the symptom not the disease'. He told Radio 4's

Today programme that he could run the market economy better than the Conservatives.' The interviewer replied that 'it is a long time since a Labour leader has said: 'Vote for me because I know more about a market economy than the Tories.' Blair didn't flinch: 'But it is absolutely true,' he said. ${ }^{267}$

\footnotetext{
${ }^{264}$ Gould (2011), p.253

${ }^{265}$ Gould (2011), p.253

${ }^{266}$ Blair (2011), p.96

${ }^{267}$ Gould (1998a), p.218
} 


\subsection{Brand agent}

In this section, I look at the primary brand agent, Tony Blair, and how he relates to the New Labour brand. In the introduction part of the product life-cycle, the primary brand agent, Tony Blair, was strong and he personified the New Labour brand. Like New Labour, Blair was different to old Labour, he was young and charismatic and as Gould stated he had 'the pulse of the people.'268 Figure 4.2 shows that more people were satisfied with Blair's performance as opposition leader than dissatisfied.

\section{Figure 4.2 Tony Blair's Satisfaction Rating as Opposition Leader (1994-1997)269}

Blair's Satisfaction Ratings as Opposition Leader (1994-1997)

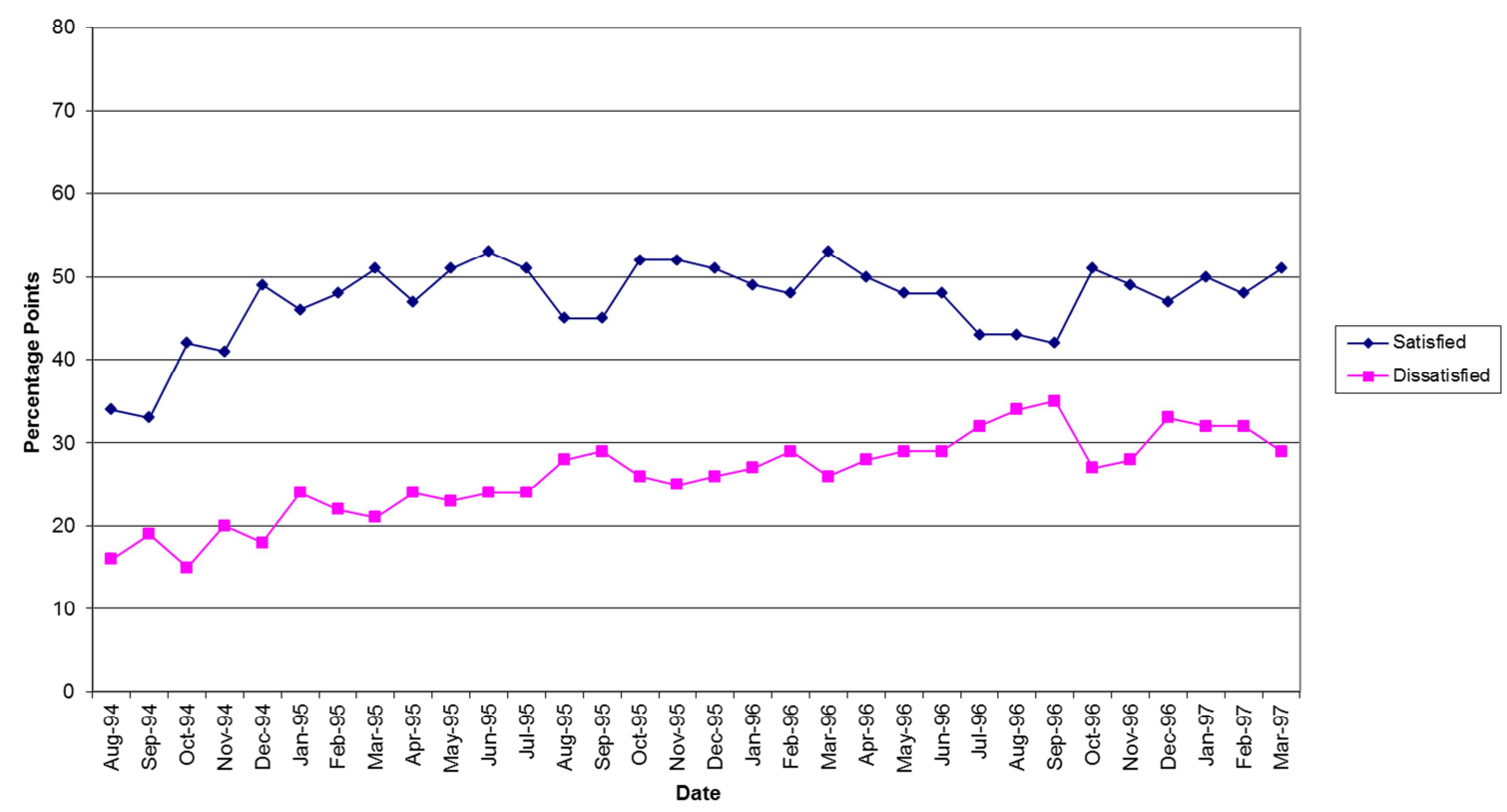

${ }^{268}$ Gould (2011), p. 188

269 'Political Monitor - Satisfaction Ratings 1988-1997' (1997) Ipsos MORI Website, Accessed 16 February 2013 <www.ipsos-mori.com/researchpublications/researcharchive/poll.aspx?oItemID=2438\&view=wide> 
Figure 4.3 ICM Polling Data 1992-1997270

ICM Polling Data 1992-1997

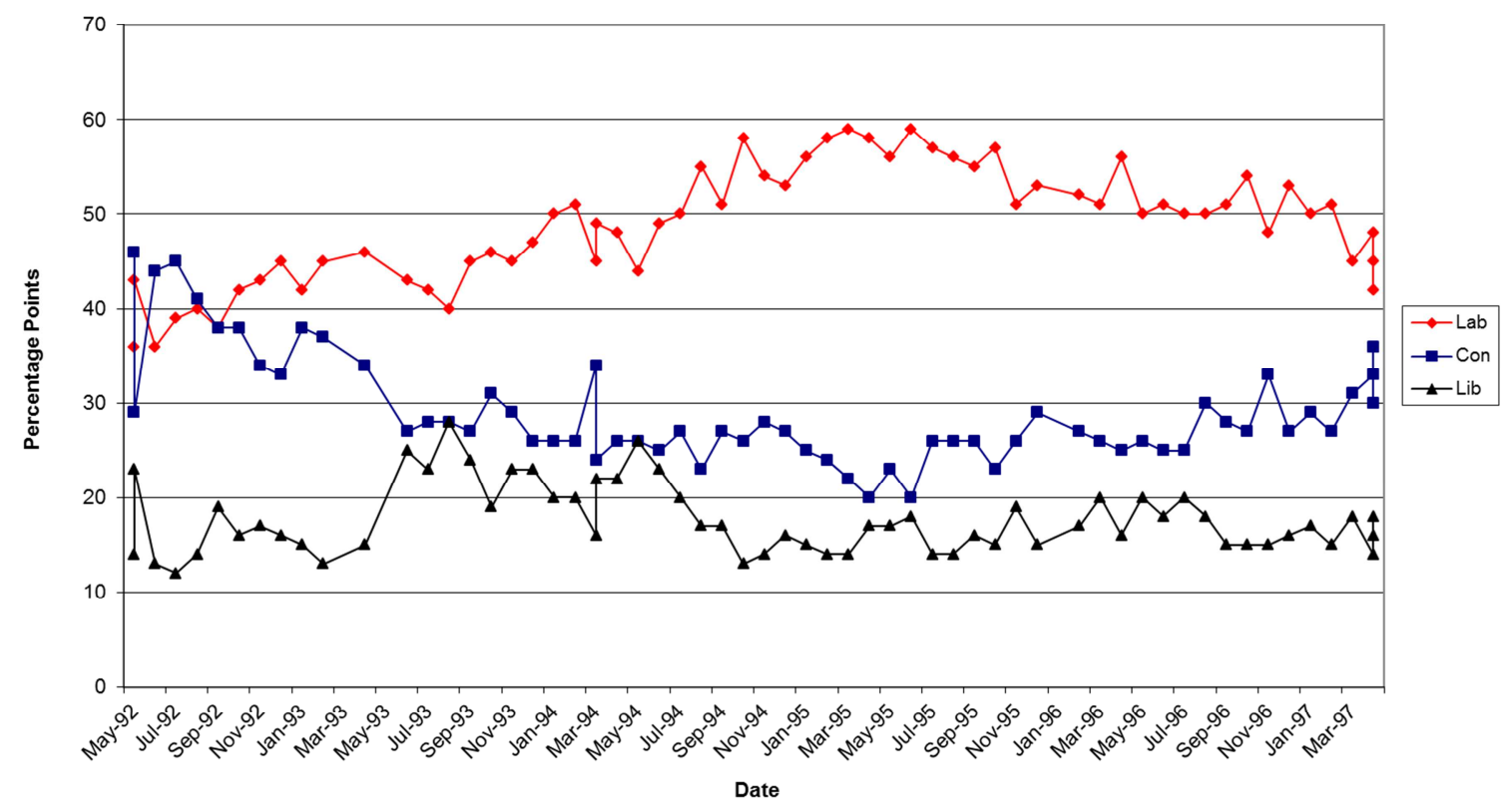

The data in figure 4.3 shows that New Labour had a large lead over the Conservatives, even before Tony Blair was elected leader in 1994. However, after Blair's election as leader, Labour's share of the vote was between 50 and 60 per cent, until November 1996, closer to the general election. Figure 4.3 suggested that the creation of New Labour gave the party a boost in the polls, and it could be argued that it was Blair's leadership that gave the party this boost. However, figure 4.2 shows that Blair's personal rating, even though high, was lower than the party's rating. Using this analysis, both the New Labour brand and the primary brand agent were strong during this phase.

Using Vincent's brand narrative chart, (Figure 2.3) when both the brand narrative and the primary brand agent are strong, it has a symbiotic relationship. As this chapter has shown New Labour needed a modernising figure like Blair to succeed, and Blair needed to be able to modernise the party to establish his credibility. Therefore in this part of the product life-cycle the brand

270،Guardian / ICM Polls: everyone since 1984' accessed 19 April 2013
<www.guardian.co.uk/news/datablog/2009/oct/21/icm-poll-data-labour-conservatives> 
and the primary brand agent had a symbiotic relationship and were dependent on each other.

\subsection{Summary}

New Labour in the product development and repositioning cycle of the product life-cycle is summarised as:

Product

- New Labour's policies were market-oriented.

- The party used detailed pledges to outline policy.

- The party itself was reformed giving the leadership more control over policy.

- The party was unified.

Position

- New Labour was the challenger and challenged the market-leader (the Conservatives) head-on.

- New Labour accepted the changes that the Conservatives had made in the past.

- New Labour took on policies that the Conservatives had traditionally been strong in, such as law and order and the economy.

- New Labour professionalised the way it worked with the media.

- The market-leader was in the decline phase of the product life-cycle model.

Brand narratives

- The narrative that 'New Labour is different to old Labour' was established in 1994-95 and was reinforced in the lead up to the 1997 election.

- The primary brand agent personified New Labour.

- Pseudo-events were used to show that the party had changed.

Brand agent

- Symbiotic relationship between New Labour and Tony Blair. 


\section{Growth}

During the 1997 election campaign New Labour maintained the momentum that it gained during the introduction cycle, which enabled it to push through to the growth cycle of the model. I have identified the period between May 1997 and September 2001 as the time when New Labour moved into the growth cycle of the product life-cycle model. During that time New Labour was given the opportunity to test the product and to maintain the support that it had gained in the election.

During the growth cycle:

- The political product makes the transition from opposition to government.

- The political product is expected to deliver on the promises that it made.

- The brand established in the previous cycle is reinforced.

- The political product is at its strongest.

- The brand agent is also at his/her strongest.

When Tony Blair entered Number 10 on 2 May, 1997, the transition of power to New Labour was shown with the symbolism of cheering crowds waving flags, with Blair and his wife, Cherie, walked heroically down Downing Street. On the doorstep of Number 10, Blair declared and reassured voters that 'I say to the people of this country - we ran for office as New Labour, we will govern as New Labour.'271

The growth cycle, as described by Kotler and Armstrong, is 'a period of rapid market acceptance and increased profits;';72 figure 2.1 also suggested that there is a large increase in profits during this time. In terms of a political product, there is acceptance of the product because it has gained enough support to become government, which means that the party is now able to deliver on its promises. However, unlike the product life-cycle model, there is no rapid increase

${ }^{271}$ Rawnsley (2001) p.15

${ }^{272}$ Kotler and Armstrong (2012), p.273 
in profit or support throughout the growth phase. New Labour received a rapid increase in support when it was elected in 1997, this support increased during its honeymoon phase but by the 2001 election, when New Labour was re-elected with a small dip in support. For example in 1997 Labour received 13,518,167 votes (43.2 per cent) winning 418 seats and in 2001 it received 10,724,953 votes (40.7 per cent) winning 418 seats.

This chapter analyses New Labour's product, positioning, brand narrative and brand agent during its growth phase. In my model the growth cycle is where the party makes its transition from 'challenger' to 'market leader'. At the beginning of the cycle it is the challenger and quickly becomes the market leader.

\subsection{Product}

In this stage of the product life-cycle the New Labour product that was developed in the previous stage, was tested for the first time. This section looks at the difficulties that New Labour faced when its product was first tested as well as the further changes that were made to the party as well as changes to governing. This section is divided into four parts:

- Further changes to the party.

- Changes to 10 Downing Street.

- Delivery of policies.

- Sales-oriented approach to foreign policy.

\section{Further changes to the party}

During this part of the cycle New Labour still had a use for members at the grassroots; their function was to legitimise the decisions already decided by the leadership. ${ }^{273}$ However, the party continued to its centralisation by creating a plebiscite party where the leadership had the ease and ability to implement market-oriented policies (as well as sales and product oriented policies) without resistance from the party membership.

${ }^{273}$ Seyd and Whiteley, p.173 
In office New Labour has continued to reform the party; this included:

- Downgraded the role of party activists in the selection of candidates, giving the NEC and party membership greater power. ${ }^{274}$

- Candidates who were selected 'sign a form agreeing to abide by the code and conduct of the Parliamentary Labour Party. ${ }^{275}$

- The leadership also had a greater say with the selection of candidates to the European and Scottish parliaments. ${ }^{276}$

- The establishment of policy forums where party policies were developed by committees and were developed and reviewed. The conference acted as a 'final reading' for policy. Once a policy was endorsed by conference, it was eligible to become a part of the next manifesto, but the final decision on the manifesto was left to a forum of Cabinet and NEC representatives.

Party members were willing to change their party for electoral gain. In 2002 Seyd and Whiteley conducted a study looking at the attitudes of party members towards the party's strategy. Party members were 'uneasy about the Blair strategy of capturing the votes of middle England. ${ }^{277}$ However, they did not want to lose an election by 'rigidly standing by their principles.'278 Membership did believe that the leadership was too powerful and did not pay attention to the views of ordinary members, but 71 per cent were satisfied with Blair as leader and 62 per cent approved the of the government, those who had less enthusiasm with the government identified with the party's left. 279

Likewise the new Labour MPs showed loyalty to the party, Nicholas Jones observed that the new MPs were 'dutiful [in the] way which they responded to

\footnotetext{
${ }^{274}$ Stuart Thompson (1999), 'The Changing Structure of the Labour Party: A Leader-Centred Party?,' p.12

${ }^{275}$ Thompson, p. 12

${ }^{276}$ Thompson, p.12-15

${ }^{277}$ Seyd and Whiteley, p.151

${ }^{278}$ Seyd and Whiteley, p.151

${ }^{279}$ Seyd and Whiteley, p.161
} 
the pager messages sent out by Millbank and for their willingness to parrot the party lines that were faxed to their offices each morning in the Daily Brief.' 280

In the growth part of the life-cycle, the Labour remained relatively united. Reforms to the party continued to centralise the party reducing voter's fear of a Labour Party in government divided by activists as was the case of the previous Labour government. Party members appreciated that changes to the party were needed and it was better for the party to be in government delivering than in opposition rigidly sticking to its principals.

\section{Changes to Downing Street}

In addition to the changes made to the Labour Party itself, Blair also made changes to the Prime Minister's Office. In opposition New Labour was a centralised organisation which was centred on the leader and his inner circle and Blair was keen to keep this arrangement when as prime minister. ${ }^{281}$ Just after becoming Prime Minister, the following changes were made:

- The ministerial rulebook, Questions of Procedure for Ministers was changed and reorganised as The Ministerial Code. The code reinforced that ministers needed to 'consult Number 10 before releasing information, undertaking major media interviews, launching policy initiatives or making appointments.' 282

- In November 1997, the Strategic Communications Unit was created - The united was created so that the government had a clear message. Its task was 'coordinating the release of departmental statements so as to eliminate clashes and ensure effective take-up in the media.'283

- Blair's style of government was different; he used face-to-face contact with ministers and was not as involved with cabinet committees. ${ }^{284}$

\footnotetext{
${ }^{280}$ Nicholas Jones (2001) The Control Freaks: How New Labour Gets Its Own Way, Politico's London pp.4-5

${ }^{281}$ Martin Burch, Ian Holliday (2004) 'The Blair Government and the Core Executive' Government and

Opposition, vol.39:1 January 2004 pp.4-5

${ }^{282}$ Burch and Holliday, p.5

${ }^{283}$ Burch and Holliday, p.5

${ }^{284}$ Burch and Holliday, p.7
} 
However, it was not realistic for Blair to make changes to Downing Street to replicate Millbank. Gould observed that before coming into government the New Labour modernisers worked closely together. But now that they were in government they were separated by different departments. Gould stated that 'a meeting with Tony Blair took place within one kingdom, a meeting with Gordon Brown within another.'285 As opposition MPs, the leaders of New Labour could easily work together, but when they got into office, this became difficult due to the responsibilities of being in office and each minister running their own department.

After the 2001 election Blair made further changes to his office by creating a Strategy Unit and a Delivery Unit, which worked alongside the Policy Unit. The Strategy Unit focused on long term policy and according to Hyman the unit used data from 'competitor' countries, 'trawled the latest research and data, interviewed ministers and civil servants about the key challenges in their area, and came up with a view about what Britain needed. Party polling and information from other social research gave us a detailed sense of what the public wanted'286 The unit looked at medium and long term issues and tried to keep on top of 'looming but no imminent' issues. ${ }^{287}$ In terms of political marketing, and putting the voter and customer first, the above quote from Hyman suggest that the unit did use party polling and there was a real attempt to find out what political market wanted.

The Delivery Unit was initially headed by Professor Michael Barber. Goal of the unit was to monitor the performance of four departments - Department of Health, the Home Office, the Department of Education and Skills and the Department of Transport. In 2007 Barber wrote his own book where he 'outlined the need for delivery reports, setting targets, consideration of delivery chains, an

\footnotetext{
${ }^{285}$ Gould (2011), p.417

${ }^{286}$ Peter Hyman (2005), 1 Out of 10: From Downing Street Vision to Classroom Reality, Vintage London p.246

${ }^{287}$ Blair (2011) p.339
} 
assessment framework and simple presentations to the media. ${ }^{288}$ Blair found the unit 'utterly invaluable' because it 'focused like a laser on an issue, draw up a plan to resolve it working with the department concerned, and then performance-manage the solution.' 289

The above changes that Blair made to the way his personal office in Downing Street suggests that he did have political marketing in mind. By reigning in government announcements, New Labour ensured that the brand was focused and was delivering clear and simple messages. A focus on delivery ensured that the government was able to make real change. The Strategy Unit using social research and party opinion poll data also suggests that the views of the political consumer were taken into account in the development of medium and long term government policy.

\section{Delivery}

In the previous stage of the product life-cycle, New Labour developed a product that was market-oriented; its policies best reflected the political market. However, it was not in government and was not able to deliver its policies. In the growth stage of product life-cycle New Labour was in government and had the power to deliver. According to Lees-Marshment, delivery is difficult in politics; 'It involves not just delivering policy goals through legislation and system changes but maintaining the overall brand and product communicated before the election.'290 This section is divided into two parts. First, Blair found that the civil service was resistant to change and delivery. Secondly, I ask to what extent was New Labour market-oriented at this time.

\section{The pace of change}

Blair was frustrated at the pace of change, stating that in his first two years there had been progress but it had been slow, he stated that the reason of this was due to money but there was also 'a structural problem that money alone

\footnotetext{
${ }^{288}$ Lees-Marshment (2009), pp.205-206

${ }^{289}$ Blair (2011), p.338

${ }^{290}$ Lees-Marshment (2009), p 205
} 
couldn't solve. Across the piece - in schools, universities, the NHS, law and order and criminal justice - we were still only tinkering, not transforming.' ${ }^{291}$ The government's declared, 1999 the 'year of delivery', did not produce results, and he became frustrated. At a conference he stated "You try getting change in the public sector and public services, I bear the scars on my back after two years in government."292 Blair further stated that:

As we began to try and drive change in the public service, in welfare, in law and order, it became obvious that there were major 'c' conservative interests within the services that were hostile to change, essentially vast vested interests that were pretty unscrupulous about defending themselves on the spurious grounds of defending the public interest. ${ }^{293}$

During its first year in government, people where positive about New Labour. However, in the second year there was some concern from voters: 'focus groups held among switchers to Labour from the Conservatives were divided between the promise of hope and the pace of delivery.'294 Some of the comments from the focus groups were:

- Blair has charisma.

- More modern.

- Hope for the future.

- Maybe a slow start on some issues.

- Very slow on education, health service, seem to have ideas they do not follow through.

- Talk but does not deliver. ${ }^{295}$

\footnotetext{
${ }^{291}$ Blair (2011), p.255

${ }^{292}$ Quoted from Seldon (2004), p.423

${ }^{293}$ Blair (2011), p. 254

${ }^{294}$ Gould (2011), p.421

${ }^{295}$ Gould (2011), p.421
} 
Lees-Marshment noted that even if a political party succeeds in delivering what the political consumer wants, political consumers may not give them credit.296 This was the case with New Labour, half way through its first term Gould's public opinion research showed that the public criticised the government for not delivering, but they could not say what it had failed to deliver nor say what it had achieved.297 Lees-Marshment further noted that in 2006 a poll showed that voters thought that under Labour 'services got worse and not better.' ${ }^{298}$ However, a survey showed that 71 per cent of people had a good experience using the NHS. ${ }^{299}$

During this part of the cycle, political consumers have high expectations that the new government will deliver. But in the case of New Labour there were factors that stalled delivery of products, such as the resistance of the civil service and the ministers were new to government, they had a strong mandate, but did not know how to govern. On coming into power people did have high expectations of New Labour. This might have been a deliberate strategy of New Labour, or perhaps the leaders of New Labour had no idea of the challenges they would face delivering on policy in government.

\section{Delivery in the growth cycle}

Labour did succeed in areas like constitutional reform and the introduction of the Scottish Parliament and the Welsh Assembly, but Labour did not make substantial improvements to public services. ${ }^{300}$ In 2000, Gould produced a memo called 'recovery and reconnection' it showed that people thought the government was doing well with the economy and education, but was making slow progress on anything else, which made Blair frustrated. ${ }^{301}$ However, Labour did achieve the following changes:

\footnotetext{
${ }^{296}$ Lees-Marshment (2009), p.206

${ }^{297}$ Gould (2011), p.431

${ }^{298}$ Lees-Marshment (2009), p.206

${ }^{299}$ Lees-Marshment (2009), p.206

300 Jennifer Lees-Marshment (2004) The Political Marketing Revolution: Transforming the Government of the $U K$, p. 21

${ }^{301}$ Seldon(2004), p.433
} 
- Independence for the Bank of England.

- Belfast Agreement.

- Human Rights Act.

- Freedom of Information Act.

- Scottish Parliament.

- Welsh Assembly.

- Introduction of a minimum wage.

Without an in-depth analysis of New Labour's policies and their delivery it will be hard to determine how many policies were market-orientated. However, opinion polling data before 2001 does suggest that New Labour did have a market-orientation. Or that it was closer to the market than the opposition. For example, in a Mori poll in the lead up to the 2001 election, voters identified the following issues as important to them and most likely to determine their vote:

- Healthcare (59 per cent)

- Education (50 per cent)

- Law and Order (41 per cent)

- Pensions (31 per cent)

- Taxation (28 per cent). ${ }^{302}$

The next question asked which party had the best policy for the above issues and it showed that Labour dominated the Conservatives on health, education and pensions. For example 43 per cent believed Labour's policy on health care was the best, compared to 15 per cent for the Conservatives. Forty per cent believed Labour's policy was the best on Education compared to 15 per cent for the Conservatives. However, Labour and the Conservatives were close on Law and Order and Taxation, with 29 per cent saying Labour had the best policy on Law and Order compared to 31 per cent for the Conservatives. And both parties were tied on taxation at 32 per cent. This data suggests that New Labour's policies for

\footnotetext{
302 'General Election 2001: Pre-Campaign Survey' (2001), Ipsos MORI website, Accessed 15 March 2014, $<$ www.ipsos-mori.com/researchpublications/researcharchive/1217/General-Election-2001-PreCampaignSurvey.aspx $>$
} 
the main issues were in-line with the political market, or more in-line to the political market when compared to the Conservatives. This perception would have been created by Labour's 2001 campaign promises as well as from its record in office.

In conclusion, Labour did have trouble delivering market-oriented policy and this experience showed Blair that more attention needed to be placed on public sector reform. ${ }^{303}$ Also evidence suggests that even if New Labour followed a 100 per cent market-orientation and delivered on every aspect of the political consumers' demands, it probably would not be noticed, or they would receive little credit for it. However, by the 2001 election polls showed that New Labour's policies were still closely aligned to the political market, more so than the Conservatives. This does not necessarily show that New Labour had a market-orientation, but it does show that they were more close to the market than the Conservatives.

\section{Sales-Oriented approach to foreign policy}

As stated above, New Labour had problems delivering some of its marketoriented policies. In the area of international relations, Blair undertook a salesoriented approach. Lees-Marshment identified the factors that may challenge a government's market-orientation. These include the 'realities and constraints of government' and the 'increased knowledge, experience and information among leaders, encouraging feelings of invincibility, arrogance and superiority. ${ }^{304}$ In this section, I argue that Blair's experience in foreign policy during the growth phase of the cycle shifted his style of leadership from a market-orientated 'consensus building' politician to a conviction politician. Gould argued that Blair made the shift from a consensus politician to a conviction politician in 1999.305

Blair admitted that the 1997 election campaign was fought on domestic policy and that despite knowing a lot about history he did not know much about foreign

\footnotetext{
${ }^{303}$ Seldon (2004), p.423

${ }^{304}$ Lees-Marshment (2009), p.209

${ }^{305}$ Gould (2011), p.417
} 
affairs on taking office. ${ }^{306}$ Blair's Chief of Staff, Jonathan Powell, later wrote that when elected, new prime ministers have little intention on spending time on foreign policy, they are more concerned about domestic policy. Over time prime ministers 'find themselves dragged into foreign policy, usually in their first term, and over time they come to enjoy it more than domestic policy.'307 In his first term Blair dispatched British Forces into three arenas: Iraq (1998), Kosovo (1999) and Sierra Leone (2000). This section focuses on Kosovo.

\section{Kosovo}

The conflict in Kosovo was an 11 week NATO aerial war against Yugoslavian President Slobodan Milošević, whose Serbian forces were carrying out a campaign of ethnic cleansing of Kosovo Albanians. Blair stated that the Kosovo conflict gave him many lessons about leadership and that his position on foreign policy evolved during the crisis. ${ }^{308}$

During the conflict, Blair believed that the "primary instinct of the international community was to act,' and he advocated a military solution, including the use of ground troops. ${ }^{309}$ However, as the conflict unfolded Blair and his advisors saw the limitations of polling and market orientated politics when confronted with the idea of sending ground troops to Kosovo. Rawnsley observed that:

The heart of the problem was that Clinton was terrified of American public opinion, which the White House was polling daily. There was a blackly comic side to this. At Clinton's feet had New Labour been tutored in the use of polling to give the people what pleased them. His ability to flex the public mood had been admired by New Labour as it had been aped. Now, Tony Blair was confronted with the limits of governing by opinion poll. He was doing some polling himself. Philip Gould

\footnotetext{
${ }^{306}$ Blair (2011), p.224

${ }^{307}$ Powell, p.262

${ }^{308}$ Blair (2011), p.227

${ }^{309}$ Blair (2011), p.227
} 
was sampling public opinion to define how the conflict was playing with the British electorate. But even the focus group guru regarded his results as of dubious value. 'Ignore it,' Gould advised Blair. 'The only important thing is to win.' The British public would tolerate anything except a defeat. ${ }^{310}$

The conflict showed a shift in Blair from a market-oriented politician of consensus to a more sales-oriented conviction politician. During the conflict in a speech in Chicago in April 1999 Blair outlined 'A Doctrine of the International Community' which basically outlined the grounds in which international intervention should be justified on dictatorships 'on the grounds of the nature of that regime, not merely its immediate threat to [national] interests.' ${ }^{311}$ Blair set out five major considerations:

- Are we sure of our case?

- Have we exhausted all diplomatic options?

- On the basis of a practical assessment of the situation, are there military options we can sensibly and prudently undertake?

- Are we prepared for the long term?

- Do we have national interest involved?312

The above speech shows there was a shift away from a market-oriented approach, especially with foreign policy. Of Blair's five major considerations there was no mention of the voter or political consumer. Their views were ignored and the speech show's Blair's shifted away from consensus politician to a conviction politician, especially in foreign affairs. However, on the other hand, it can be noted that Blair did fulfil the role of a strong and decisive leader, which is a quality that the political consumers often demand.

\footnotetext{
${ }^{310}$ Andrew Rawnsley (2001), Servants of the People: The Inside Story of New Labour, Penguin, London p.281

${ }^{311}$ Blair (2011), p.248

${ }^{312}$ Blair (2011),p.248
} 
However, Blair's shift to a conviction politician did not mean that Blair abandoned political marketing in this conflict; he still placed importance on communicating his policies to the political market and adopted a salesorientation. For example, during the crisis a clone of Millbank election machine was created at NATO headquarters to ensure that the war was properly communicated. As observed by Rawnsley, Blair:

dispatch[ed] Downing Street's elite company of para-spinners to Brussels. Jamie Shea, the NATO spokesman, who had been floundering trying to reconcile the contradictory information about the refugee bombing, received a warning call from a friend in Washington to brace himself for an imminent appearance by Alistair Campbell. When he got to NATO headquarter on Thursday, the press secretary was horrified. NATO, never before having fought a war, was hopelessly inadequate to a propaganda battle. 313

Gould's focus groups showed that there was no 'public acclaim' for Blair's success in Kosovo, instead the public were concerned about Blair's 'passion for war' and that he was not as passionate about domestic affairs. People were not concerned about the situation in Kosovo, instead they wanted 'their own country fixed."314 However, during the conflict a MORI Poll indicated that 70 per cent of Britons polled thought that Britain's aerial campaign against Yugoslavia to stop ethnic cleansing was the right thing to do. ${ }^{315}$ Even 51 per cent supported the use of ground troops. 316 This may suggest that the sales-oriented approach to the conflict paid off for the government.

\footnotetext{
${ }^{313}$ Rawnsley (2001), p.265

${ }^{314}$ Rawnsley (2001), p. 290

315 'Local Elections, Kosovo and the Tory Leadership,' (1999) Ipsos MORI Website, Accessed 16 March 2013 <www.ipsos-mori.com/researchpublications/researcharchive/1861/Local-Elections-Kosovo-and-the-ToryLeadership.aspx>

316 'Local Elections, Kosovo and the Tory Leadership,' (1999) Ipsos MORI Website, Accessed 16 March 2013 $<$ www.ipsos-mori.com/researchpublications/researcharchive/1861/Local-Elections-Kosovo-and-the-ToryLeadership.aspx>
} 
Kosovo gave Blair a false understanding of the reality of war. In the case of Kosovo, Blair was proved to be correct, even though the political market never specifically sought military intervention in Kosovo. Blair felt that his actions were justified because there was a quick resolution to the conflict and an end to ethnic cleansing in Kosovo. The war did not show a complete departure from political marketing due to the emphasis on communications.

\section{Conclusion}

In the growth part of the product life-cycle, reform of the Labour Party continued when New Labour entered government. It also extended its centralisation reforms to Downing Street. In domestic policy New Labour did try to implement market-oriented policies, but this was not always easy due to the civil service. In foreign policy there was shift from a market-orientation to a sales-orientation. Also Blair made the shift to a politician of conviction. As Gould observed:

The relationship between the public and politicians is complex. Modern government, probably all government, requires a balance between conviction and consent; you cannot lead effectively without both. The public want leadership with purpose, leadership that can be believed in, but they also want to be listened to and to be involved in the process of government. ${ }^{317}$

It is easier for a political product in opposition to be market-orientation because it does not have to deliver on policies, nor does it have to be reactive to international event. In power a political product like New Labour still had a market-orientation and best represented the political market, while it also took on a sales-oriented approach in other areas like foreign affairs. This supports the above quote from Gould that argued that a government needs a balance between conviction and consent.

${ }^{317}$ Gould (2011), p.417 


\subsection{Positioning}

New Labour became the market leader in the political market in 1997 by becoming the government. Labour won 418 seats, 43.2 per cent of the popular vote which translated to a majority of 179 seats. An estimated 1.8 million Conservative voters switched to Labour between 1992 and 1997.318 The nature of the first past the post electoral system gave the new market-leader a boost. Even though it did not receive a majority of the popular vote, it did have an overwhelming majority of seats in the new Parliament.

The goal of a market leader is to expand 'the total market, expanding market share further and defending [its current] market share.'319 Butler and Collins concede that it is difficult for it to expand a market share when the market leader already has broad appeal, therefore the market leader will mainly be on the defensive. 320 Gould emphasised that the goal of New Labour was not just winning the next election, but building long-term support so that the parties long-term goals could be achieved. ${ }^{321}$ Gould saw parallels with the Conservative Party which successfully showed its pragmatism and adaptability, which allowed the party to reinvent it to suit the current political climate. ${ }^{322}$ Gould's analysis implies that constant rejuvenation was required to defend its market share.

Four factors that helped New Labour defend its market share in the first term. Firstly, it placed a lot of effort and emphasis on building consensus, being a government that included everyone in the country. Secondly, in government the party continued to have policies that appealed to the centre. Thirdly, it placed emphasis on communication management, or 'spin'. Finally, New Labour faced a weak opposition.

\footnotetext{
${ }^{318}$ Gould (2011), p.387

${ }^{319}$ Collins and Butler (2002), p.7

${ }^{320}$ Collins and Butler (2002), p.8

${ }^{321}$ Gould (1998a), p.239

322 Gould (1998a), p.239
} 


\section{Building Consensus}

In the first term, the government placed an emphasis on building consensus, even with those who traditionally voted for the Conservatives. Rawnsley argued that this approach was tactical: by drawing in the moderate Conservative it left the opposition front bench looking like extremist Tories. ${ }^{323}$

In contrast to Thatcher's 'divide and rule' policies in the 1980s, New Labour made attempts to show that it was an inclusive government for all Britons. Blair did this by working with moderate members of the Conservative Party, for example former Conservative Cabinet Minister and Deputy Prime Minister Michael Haseltine was a regular visitor to Number 10, discussing the Millennium Dome project and former Conservative Chairman and the last Governor of Hong Kong, Chris Patten, became the chairman of the Commission of Inquiry into the Royal Ulster Constabulary. It was also noted that Blair was always inclusive in his speeches, he often used the word 'we' which was a similar tactic used by the Conservatives such as Rab Butler and Edward Heath that historically spoke about 'one nation' which has a 'sense of the organic unity of a highly differentiated body politic or used it in opposition to divisions between two nations of rich and poor. ${ }^{324}$

\section{Policies}

As stated in the previous section, New Labour continued to have market-oriented policies during this part of the cycle, with the exception of foreign policy. As the market-leader Labour defended its market-share by retaining its marketorientation.

\section{Spin}

As the market-leader, New Labour in government changed the way that a government communicated. It continued the grid of media announcements,

\footnotetext{
${ }^{323}$ Rawnsley (2001), pp.199-200

${ }^{324}$ Richard Rose (2002) The Prime Minister in a Shrinking World, Polity Press, p.255
} 
parcelling out released to fit the government's narrative. The grid, held at Downing Street, metered out policy, controlling the agenda.'325 The Strategic Communications unit found ways to get Blair 'beyond the headlines to enhance the prime minister's message, by trying to reach, for instance, women's magazines.' ${ }^{326}$ Alistair Campbell, 'the prime minister's official spokesman', was also known for his combative briefings to the media which within time became part of the story. ${ }^{327}$

As the market-leader New Labour was criticised by its communications strategy which was also known as 'spin.' Labour's communication strategy was defined by its past, it still remember the aggressive media attacks that Kinnock received as leader and also it needed to find a way to adapt to the 24 hour news cycle. Also Hyman observed that a focus on communication strategy is important because 'ordinary people are too busy dealing with their lives 'without much thought for the ins and outs of politics.'328 People do not notice most government announcements because most they 'last less than twenty-four hours in the media.' 329

Gould stated that it was aiming to meet the challenge of governance in a frenzied and relentless media age...good government requires consent, communication and the capacity to act quickly and decisively in the face of continuous media and incredibly fast-moving events. ${ }^{3} 30$

\section{The Opposition}

The Conservatives were not an effective challenger to Labour. The opposition was weak, divided and poorly led by William Hague. In the 2001 election campaign it focused on Britain's relationship with the European Union. Their big

\footnotetext{
${ }^{325}$ Will Woodward (2007), 'Spin and Scandal: How New Labour made the news' The Guardian, Accessed 24 Jun 2013, < www.theguardian.com/media/2007/jun/13/politicsandthemedia.pressandpublishing>

${ }^{326}$ Woodward

327 Woodward

${ }^{328}$ Hyman, p. 259

${ }^{329}$ Hyman, p. 259

${ }^{330}$ Gould (2011), p.469
} 
election slogan in the election was 'ten days to save the pound.'331 Pre-election surveys showed that only 18 per cent believed that Europe was an issue that helped determine their vote. ${ }^{332}$ Gould's opinion polling in 2000 showed that the public thought the Conservatives were 'weak, divided and useless' but the party's hard line stance on Europe, crime and welfare was noted. ${ }^{333}$

Without going into too much detail about the weaknesses of the Conservative Party at this time, in terms of the life-cycle model the party was still going through its decline phase and trying to introduce a new product to the political market that did not appeal to political consumers. As the previous chapter showed, a challenger needs to have sorted out its own internal divisions before it can become an effective challenger. In the 2001 election the Conservatives were focusing on retaining its own base and not challenging the government for the middle ground.

\section{The 2001 election}

During the growth period of 1997-2001, New Labour dominated the political market as the market leader. It continued and built on its success as the challenger. In the 2001 election, Labour went from 43.2 per cent to 40.7 per cent of the vote. It retained a healthy majority of 167 seats. Even though the goal of a market-leader's goal is to build on the support it received, realistically a political party will only be at its height after its first election to office and after that it is trying to retain power. That was the case of New Labour, the 1997 election was the best result it would receive while in government. The low turnout in the 2001 election of 59.4 per cent could be seen as a sign of voter apathy. However, Blair argued that the turnout was not a reliable reflection of the government and that in elections that are close, voter turnout is much higher, while in elections where the incumbent is a shoo-in, turn out is lower. ${ }^{334}$

\footnotetext{
${ }^{331}$ Gould (2011), p.446

332 'General Election 2001: Pre-Campaign Survey' (2001), Ipsos MORI website, Accessed 15 March 2014, $<$ www.ipsos-mori.com/researchpublications/researcharchive/1217/General-Election-2001-PreCampaignSurvey.aspx >

${ }^{333}$ Gould (2011), p.439

${ }^{334}$ Blair (2011), p.336
} 
Interestingly, in Blair's biography, he stated that even though it was certain that Labour was going to win the 2001, Clinton advised Blair to 'fight the campaign as if it were neck and neck, to show the people how much you want it, how much you are prepared to fight for it, and how grateful you are for every last vote you are going to get.'335 This suggests that even when the market-leader is in a comfortable position, it should still behave like a challenger during an election campaign.

\section{Conclusion}

As the market-leader, New Labour retained its position in the growth cycle. It successfully defended its market share by being more in touch with the political market than its main challenger. It also maintained this position by maintaining market-oriented policies, building a consensus with the community and focusing its attention on its communications.

\subsection{Brand narrative}

In the growth cycle New Labour's brand narrative had the political consumer in mind. In the growth cycle, the party continued to use symbolism as part of its narrative. The brand narratives that were created in opposition were centred around trust and the idea the New Labour would be different in government and that it could deliver. The government used symbolism to present its narrative to political consumers.

\section{Symbolism}

In the previous chapter, I stated that New Labour used pseudo-events as part of its narrative. In the product development and reintroduction cycle New Labour had certain key stories that it wanted to tell the electorate, and they did this through events and symbolism. New Labour continued the use of pseudo-events and symbolism in government. Government by symbolism is when a government uses devices such a media releases or speeches or staged events to show that it is

${ }^{335}$ Blair (2011), p.316 
making progress on an issue. These initiatives may not actually work or deliver any change. However, the appearance that action is being taken is just as valuable. O'Shaunessy stated that 'symbol[ism] has a flexibility of meaning to whichever the viewer can bring his or her imagination - an openness to interpretation. Symbols resonate.' ${ }^{336}$

As stated above, New Labour did have problems with delivery in its first term. Also, its ability to deliver in its first two years in power was limited due to its promise to keep to the Conservative's spending plans. The challenge was to make improvements without spending new money. To do this the government used symbolism as Rawnsley observed: 'There was a frenetic wave of announcements, high on symbolism and low on cost, from the restoration of trade union rights at GCHQ (Government Communications Headquarters) to the banning of handguns.' 337

New Labour's use of symbolism has been criticised by O'Shaunessy. He stated that in the first term it used such symbolism to show it possessed authoritarian, radical, populist and liberal credentials:

authoritarian sounding threats were made - punishment for juvenile delinquents, claims that teachers would be able to be sacked in four weeks if they were incompetent and curfews for under-tens. And the liberal conscience was assuaged with claims that there would be a selective ban on weapons sales (but not Indonesia), adoption of the European Social Chapter, and adoption of the minimum-wage (but at a low rate). Their critics accused them of seeking instant policy answers to every crisis, such as Mr Blair's demand that policemen should be able to take miscreants to cash machines and fine them instantly; or of taking no decisions at all.'338

\footnotetext{
${ }^{336}$ O’Shaunessy (2003), p.303

${ }^{337}$ Rawnsley (2001), p.39

${ }^{338}$ O’Shaunessy (2003), p.304
} 
New Labour in the first term produced an annual report to outline its progress on key policies. 339 These reports have been described, by Blair as 'holding the government to account, about charting our progress against the clear promises we made.' 340 However, as Needham observed these reports were criticised for being public relations material or propaganda. ${ }^{341}$

Comparing the annual reports of 1998, 1999 and 2000 with the 1997 election manifesto illustrates the use of symbolism and narrative by New Labour; looking at prosperity, the 1997 manifesto promised to 'Deliver economic prosperity for the many not the few.' The 1998 annual report stated that the government had received a bad economic situation from its predecessor and claims that it had started reforms to stop the 'boom and bust' economic cycle to create long term stability. In 1999 the report stated that the government has been working with business. Again the report talked about how bad the 'boom and bust' economic cycle (created by its predecessors) had been bad for these business that the government was working with. In 2000 the report had more substance, talking about 970,000 more people who were in work and that the government had 'public finances under control' and had invested in the NHS 'which provides the base on which to build a stronger, fairer Britain where opportunity and enterprise are open to all.'342

The above example is rich in both symbolism and narrative. It tells the story that over four years the economy had improved and that the government had worked on eliminating the 'boom and bust' style of economics. It is creating a fairer Britain with opportunity for all. The narrative shows that the government fixed the UK economy from the mistakes of its predecessor. The above example does not say a lot about what New Labour did for the economy, it talked more about intention rather than delivery. For example, on Law and Order the 2000

\footnotetext{
${ }^{339}$ Lees-Marshment (2004), p.21

${ }^{340}$ Quoted in Needham, p.354

${ }^{341}$ Needham, p.354

342 Julian Glover, 'Labour's Changing Promises' The Guardian, Accessed 14 March 2014 <www.theguardian.com/politics/2000/jul/13/labour.labour1997to991>
} 
annual report stated that 'the rate of recorded crime in England and Wales rose by 3 per cent. But crime can be beaten. The government has increased the resources available to fight crime. Police budgets have risen on average by 3.6 per cent.' 343

This narrative of economic progress was market-oriented given Labour's historic weakness on the economy in the past. This narrative was successful, by the 2001 election, 48 per cent of people believed that Labour was the best party to manage the economy, compared to 22 per cent for the Conservatives. ${ }^{344}$ This use of symbolism to represent the government's narrative did have its problems, in a leaked memo in 2000, Gould wrote that the New Labour brand was 'badly contaminated...undermined by a combination of spin, lack of conviction and apparent lack of integrity. ${ }^{345}$ ' In a MORI poll in 200043 per cent of respondents believed that Labour would promise anything to win votes. ${ }^{346}$

\subsection{Brand agent}

During the growth period, New Labour's primary brand agent was more popular than the party itself. Throughout the first term Blair showed himself to be a formidable politician who knew how to capture the mood of the people during a crisis, for example his speech after the death of Princess Diana in 1997. He was also regarded as a competent leader. Blair had proved himself in war and on the world stage through the Kosovo crisis. However, there was a perception that Blair was 'willing to jump on every bandwagon.'347 Rawnsley described Blair as:

The most accomplished communicator of his era, a talent not to be dismissed in the age of $24 / 7$ media where a leader is constantly on show. At times of national drama or international

\footnotetext{
${ }^{343}$ Julian Glover, 'Labour's Changing Promises' The Guardian, Accessed 14 March 2014 <www.theguardian.com/politics/2000/jul/13/labour.labour1997to991>

344 'General Election 2001: Pre-Campaign Survey' (2001), Ipsos MORI website, Accessed 15 March 2014, <www.ipsos-mori.com/researchpublications/researcharchive/1217/General-Election-2001-PreCampaignSurvey.aspx >

${ }^{345}$ Needham, p.353

${ }^{346}$ Needham, p.353

${ }^{347}$ Needham, p353
} 
crisis, he displayed a high facility for capturing public sentiment and weaving it into a political narrative. When the royal family froze in self-endangering silence after the death of Diana, Blair took on the role of spokesman for the national emotion, stepping into the position vacated by the mute head of state, and helping to save the royal family from itself. With his word wreath about a 'people's princess', he expressed the feelings that Britain - or at least a large part of it - wanted to hear. It was a significant episode in his early development as Prime Minster. ${ }^{348}$

As the brand agent, Blair was always more popular than his own party as the graph below illustrates:

${ }^{348}$ Rawnsley (2010), p.5 
Figure 5.1 Satisfaction of Blair vs Labour

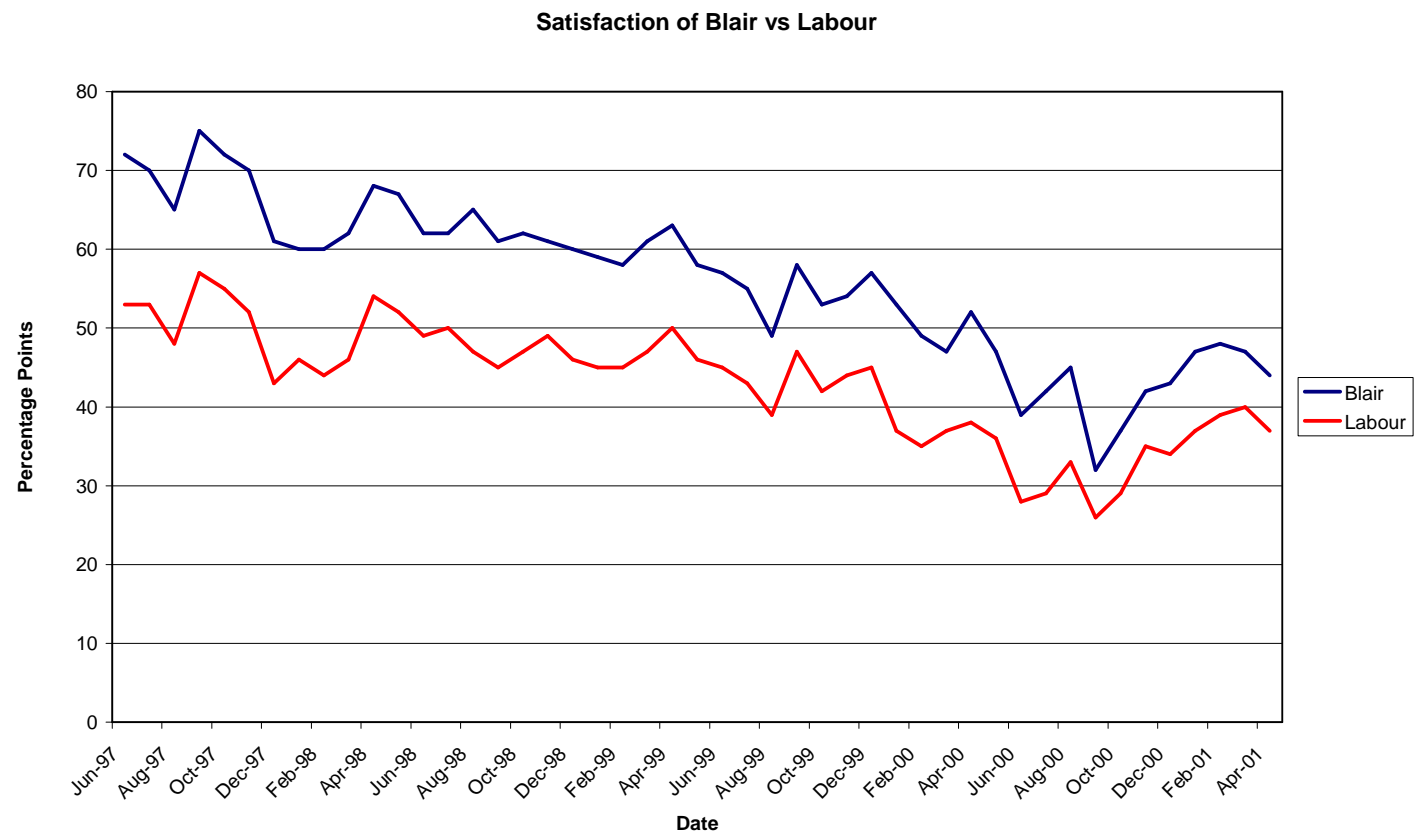

The above graph (figure 5.1) also suggests that even though Blair was more popular than his party, the trend lines followed a similar pattern. Throughout the growth cycle, overall popularity in New Labour and in Blair decreased.

However, as outlined earlier in the chapter, Blair's style of leadership shifted during this period. As he gained more experience in office he shifted away from a market-oriented politician to a conviction politician.

\subsection{Summary}

New Labour in the growth cycle of the product life-cycle is summarised as:

Product

- Reforms to centralise the party continued and were extended to the operation of Number 10.

- New Labour's policies were market-oriented, but there were problems with delivery.

- New Labour's foreign policy was sales-oriented. 
Position

- New Labour became the market leader and successfully defended its market share.

- The challenger was weak and failed to adequately challenge the market leader.

- New Labour retained its support with centrist policies and its communications strategy.

Brand narratives

- Symbolism was used to show the brand narrative.

Brand agent

- Blair was slightly more stronger than the New Labour brand. 


\section{Maturity}

In the maturity stage a political product has built up its reputation in the political market where it is still the market leader and the dominant player. Maturity is a challenge for a political product because at this stage the product is at risk of decline. As Kotler and Armstrong state: maturity is a time when the product has 'achieved acceptance by most potential buyers' and that 'profits level off or decline because of increased market outlays to defend the product against competition.' 349

In Rajagopal and Sanchez's model that adapted branding into the marketing lifecycle model, it revealed that at this stage a product's objective is to 'secure new market segments. ${ }^{350}$ To do this, features of the product are adjusted and these new features are communicated to the market. ${ }^{351}$ In political marketing terms, a party's objective in this cycle is to keep and maintain the support gained in the previous two cycles because its support has now peaked and will start to decline without rejuvenation.

Realistically political parties do not increase their support base in the third or fourth term. Generally electoral support for a government will peak in its first or sometimes second election and then decline. An example of this is the New Zealand Labour government of 1999-2008. In its first election it won 38.74 per cent of the vote, it won 41.26 per cent in 2002 and 41.10 per cent in 2005 with a decline to 33.99 per cent in 2008. New Labour also followed a similar trend to New Zealand Labour.

In the maturity stage to maintain its support a party should start rejuvenating itself to maintain its link with the political consumer. This is an opportunity for a party to readjust to prevent political consumers from switching to its competitors. Rejuvenating at this stage is important to prevent the challenger from taking ground away from the market leader. Rejuvenation can be done by

\footnotetext{
${ }^{349}$ Kotler and Armstrong (2012), p.273

${ }^{350}$ Rajagopal and Sanchez, pp.243-244

${ }^{351}$ Rajagopal and Sanchez, pp.243-244
} 
changing the party leader, having a generational change in the party or making a major shift in policy.

This chapter argues that instead of continuing its relationship with political consumers, New Labour became more consumed with international relations, especially the Iraq war and internal conflicts such as the dysfunctional working relationship between Tony Blair and Gordon Brown. Around the 2005 election, efforts were made to reengage Blair with political consumers. New Labour did attempt to regenerate in 2007 when Brown became prime minister and at first this was successful. (The next chapter discusses New Labour's attempt to regenerate in 2007).

I identify the end of 2001 as the start of New Labour entering the maturity cycle. After the terrorist attack of 9/11 there was a shift in Tony Blair's focus towards international relations at the expense of domestic policy. ${ }^{352}$ The maturity cycle ended in late 2008 when it became clear that New Labour's rejuvenation under Brown had failed and the party then shifted into a decline stage.

\subsection{Product}

The New Labour product between 2001 and 2008 was a different product from what was previously offered to political consumers. This section is divided into three parts. First I outline the changes in the party's membership, as New Labour moved into the maturity phase, its membership numbers continued to fall. Then examine further delivery problems that New Labour faced. Finally I analyse Blair's continued sales-orientation to foreign policy by examining the consequences of the Iraq War on New Labour.

\section{Party Membership}

In previous chapters, I discussed New Labour's shift to a plebiscitary model party, before entering office in 1997 there was a big push in recruiting new members. However, when Labour entered office the number of members

${ }^{352}$ Gould (2011), p.455 
declined. There was a big decrease in party membership during the growth period between 1997, where there were 405,000 members and 2001 where there were 272,000. ${ }^{353}$ The downward trend continued in the maturity stage so that by the 2005 election party membership decreased to 258,000 and by 2008 there were only 250,000 members. ${ }^{354}$ Whiteley surveyed the former members of the Labour Party and identified two main reasons why party numbers declined. Firstly, people left in protest to the Iraq war and secondly the new recruits to the party from after 1994 were not loyal grassroots members and eventually left the party. ${ }^{355}$ Whiteley also observed that since coming to power in 1997 the party paid little attention to the party membership. ${ }^{356}$

The decrease in the party's membership suggests that when a party is in its maturity stage party members are decreasing. When a political product is new it is more likely to attract new members, as New Labour did when it was in opposition. But once it starts making real decisions and focuses on governing people start to leave the party.

\section{Further problems with Delivery}

During the maturity cycle of the product life-cycle model there were divisions within the product that prevented effective delivery. The major division between Gordon Brown and Tony Blair impacted on the direction of the government. Also Labour had been relatively united in the first two cycles (with the exception of minor opposition from old left Labourites such as Ken Livingstone and Tony Benn), in this cycle there was some opposition from Labour MPs in Parliament which nearly derailed some government policy.

\footnotetext{
${ }^{353}$ Feargal McGuinness (2012), 'Membership of UK political parties,' House of Commons Library, Accessed 7 May 2014 <www.parliament.uk/briefing-papers/SN05125.pdf>

354 McGuinness

${ }^{355}$ Whiteley, p.249

${ }^{356}$ Whiteley, p.249
} 


\section{Blair and Brown}

The dysfunctional relationship between Brown and Blair was the main obstacle for the government to deliver on its policies in the maturity cycle. The relationship was a good illustration that a political product is not just building and maintaining a relationship with the political consumer. There are other factors and relationships that a political product needs to manage, such as internal and other external relationships.

After the 2001 election, Blair wanted to do more as Prime Minister while Brown was becoming obsessed with becoming Prime Minister. ${ }^{357}$ Blair was concerned with his place in history; he wanted to be bigger and bolder and focus on public service reform, he started to take control of the government's policy direction. Rawnsley noted that the real Leader of the Opposition to Blair was Brown, Brown was also concerned about his place in history. ${ }^{358}$

Gould noted that the first sign of disagreement between Brown and Blair started after the 2001 election where they started to disagree over the pace of public service reform. Blair pushed for more dramatic reform, while Brown resisted. ${ }^{359}$ Gould reflected that he often wondered in meetings if Brown's resistance to Blair was personal or political. ${ }^{360}$ Brown started to pressure Blair for a departure date, he was concerned that the longer New Labour stayed in power, the shorter his own premiership would be. ${ }^{361}$ One cabinet minister confided in Rawnsley that 'all their confrontations between 2001 and 2006 are about Gordon saying: 'Why haven't you $\mathrm{f}^{* *}$ king gone?'362 Brown did not cooperate with Blair's programme

\footnotetext{
${ }^{357}$ Rawnsley (2011), p.66

${ }^{358}$ Rawnsley (2011), p.66

${ }^{359}$ Gould (2011), p.452

${ }^{360}$ Gould (2011), p.452

${ }^{361}$ Rawnsley (2011), p.67

${ }^{362}$ Rawnsley (2011), p.67
} 
and wanted to distance himself from Blair. ${ }^{363}$ Powell argued that one of Blair's failure as a leader was not removing Brown from Cabinet earlier. ${ }^{364}$

The conflict between Blair and Brown started when John Smith died in 1994, Brown agreed not to stand for the leadership on the condition that Brown would have greater power over domestic policy under a Blair Premiership. It was also agreed that within time Blair would resign as leader handing the premiership over to Brown. This agreement essential caused division in Blair's premiership, Gould described this as 'a massive mistake.... There should have been a contest. Gordon should have stood against Tony. [The agreement] encumbered Tony with responsibilities to another member of the Cabinet which were not consistent with good Government. Gordon was encumbered with a sense of entitlement which was bad for his personality. It brought out the worst in both of them.' 365

\section{Parliamentary Party}

In the previous parts of the life-cycle, Labour MPs were loyal to Blair and New Labour. However, in this cycle there were rebellions from Labour MPs over certain policies, as seen below:

Figure 6.1 - Labour MP Rebellions

\begin{tabular}{|l|l|}
\hline Vote & Labour MPs voting against the Government \\
\hline Iraq (2003) & 139 \\
\hline Trident (2007) & 95 \\
\hline Higher Education Bill (2004) & 72 \\
\hline $\begin{array}{l}\text { Education and Inspections Bill } \\
(2006)\end{array}$ & 69 \\
\hline $\begin{array}{l}\text { Health and Social Care Bill } \\
(2003)\end{array}$ & 65 \\
\hline
\end{tabular}

\footnotetext{
${ }^{363}$ Powell, p.106

${ }^{364}$ Powell, p.127

${ }^{365}$ Quoted in Rawnsley (2011) p.62
} 


\section{Delivery in the Maturity Cycle}

Gould observed that after the 2005 election, Blair was in his element because his reforms to the NHS were working, his education programme was the right way forward and he had been coming up with solutions to deal with immigration. ${ }^{366}$ Likewise Blair was still passionate about public service reform. The irony about this is that Blair got a feel and understanding of how to govern as his time in office was drawing to an end. Gould observed that there were changes in the health and education system due to Blair's policies, while a 2011 London School of Economics report suggest that giving greater autonomy to academy schools 'generates a significant improvement in the quality of pupil intake and a significant improvement in pupil performance.'367 Another London School of Economics report also showed that between 1997 and 2007 waiting times for operations decreased. ${ }^{368}$ In a MORI poll in September 2007 (after the transfer of power from Brown to Blair) 31 per cent said Labour had the best policies in health care (compared to 20 per cent for the Conservatives). ${ }^{369}$ Likewise 32 per cent supported Labour's education policy (compared to 19 per cent who supported the Conservatives). 370

This does not show if Labour's health care and education policies were what political consumers were after. But it does show that Labour's health and education policies after ten years, best fitted to what the political market wanted, compared to the others. However, the 2007 result showed a significant drop since 1997, when 51 per cent thought Labour's health policies were the best so there had been a significant drop after 10 years in office. ${ }^{371}$ Support for Labour's education policy also took a similar drop. ${ }^{372}$

\footnotetext{
${ }^{366}$ Gould (2011), p.491

${ }^{367}$ Gould (2011), p.491

${ }^{368}$ Gould (2011), p.492

369 'Best Party on Key Issues: Healthcare' (2013), Ipsos MORI website, Accessed 16 February 2014, <www.ipsos-mori.com/researchpublications/researcharchive/poll.aspx?oItemID=23\&view=wide> 370 'Best Party on Key Issues: Healthcare' (2013), Ipsos MORI website, Accessed 16 February 2014, <www.ipsos-mori.com/researchpublications/researcharchive/poll.aspx?oItemID=23\&view=wide> 371 'Best Party on Key Issues: Healthcare' (2013), Ipsos MORI website, Accessed 16 February 2014, <www.ipsos-mori.com/researchpublications/researcharchive/poll.aspx?oItemID=23\&view=wide> 372 'Best Party on Key Issues: Healthcare' (2013), Ipsos MORI website, Accessed 16 February 2014, <www.ipsos-mori.com/researchpublications/researcharchive/poll.aspx?oItemID=23\&view=wide>
} 
It is hard to say if New Labour in the maturity cycle was still delivering marketoriented policies. Blair stated in his biography regarding reform that New Labour had a specific vision in its first term, it was unable to deliver due to the public service but by the second term 'we [had] fashioned a template of...reform'373 The template involved, according to Blair:

- Introducing competition.

- 'Blurring the distinction between public and private sector.'

- Challenging the unions and 'vested interest.'

- Freeing up the system so it can innovate. 374

Blair also stated that when reforming:

It is an objective lesson in the progress of reform: the change is proposed; it is denounced as a disaster; it proceeds with vast chipping away and opposition; it is unpopular; it comes about; within a short space of time, it is as if had always been so. The lesson is also inevitable, but rarely is it unbeatable. There will be many silent supporters as well as the many vocal detractors. And leadership is all about the decisions that change. If you can't handle that, don't become a leader. ${ }^{375}$

Even though the above passage was written by Blair after he had left office, it does suggest that Blair shifted away from a market-oriented approach. This could be because of his increased knowledge and understanding of government through personal experience. The passage says that despite protest and opposition the end product justifies the means. Likewise, Blair's template does not include any dialogue with political consumers to find out what they are after. Only the opinion polls suggest that New Labour maintained a market-oriented approach because its policies were the closest to the political market.

\footnotetext{
${ }^{373}$ Blair (2011),p.481

${ }^{374}$ Blair (2011) p.481

${ }^{375}$ Blair (2011), p.481
} 
Iraq

Blair's attention towards foreign policy shifted after 9/11. Immediately after the terrorist attacks in New York, Blair travelled across the world to drum up support for the United States' campaign in Afghanistan. Blair effectively became 'Ambassador at Large for [US President George W.] Bush.' Rawnsley observed that in this foreign policy role, Blair was enthusiastic and in his element. Blair's role also benefited the United States because a British Prime Minister can travel to the capitals of the world much easier than the President of the United States. ${ }^{376}$ Blair's appetite for the world stage had grown since involvement in the Kosovo conflict. This continuous shift suggests that as Blair became active and dominant on the world stage, his relationship with political consumers was downgraded while the relationship with the Americans and other world leaders received more attention and focus.

The Iraq war was a turning point in Blair's relationship with political consumers. In the build-up to the war, the government took a sales-oriented approach by arguing that there were weapons of mass destruction (WMDs) in Iraq and it was a direct threat to Britain's security. When it later emerged that there were no WMDs in Iraq this broke the trust between Blair and political consumers. This section is therefore divided into two parts. Firstly, I look at the sale-oriented approach to the Iraq war and then analyse the consequence of the sale-oriented approach on Labour's support. For this section I only examine the build-up to the invasion of Iraq and its subsequent invasion.

\section{A sales-oriented approach}

In later years Blair was criticised for his relationship with the Republican President. At the beginning of the Bush administration the outgoing President Bill Clinton advised Blair to 'hug him close' and 'make him your friend,' Clinton explained to Rawnsley that 'I told Tony to get close to Bush because that was the

${ }^{376}$ Rawnley (2011), p.48 
way to have influence with him.'377 Later, as the Iraq War progressed Clinton feared that Blair had taken this advice 'to extreme lengths.'378

The British public were sceptical about the intentions of the US President George W. Bush in the lead up to the Iraq war. Bush had received negative coverage in the United Kingdom since the 2000 election when he 'stole' the presidency from $\mathrm{Al}$ Gore. Humphries argued that the British public would have been more likely to support the Clinton administration (or even a Gore administration) invading Iraq because they had doubts about Bush's motives, especially due to Bush's links to the oil industry. ${ }^{379}$

The Government produced documents to convince people the case for war with Iraq shows that New Labour had a sales-oriented approach to war. When it comes to political marketing and war citizen-consumers would not seek war with another country unless:

- It is under an imminent threat from an enemy nation.

- It is retaliating against an enemy nation (or nations supporting terrorists) that has attacked them.

The Government made its case for war in September 2002, when the Joint Intelligence Committee produced a document titled Iraq's Weapons of Mass Destruction: The Assessment of the British Government. The document argued that:

- Saddam Hussein maintained an active WMD programme.

- Iraq had the capability of deploying WMDs 'within 45 minutes.'380

- Hussein had not complied with UN resolutions that had resulted from the first Gulf War. ${ }^{381}$

\footnotetext{
${ }^{377}$ Rawnsley (2011) p.28

${ }^{378}$ Rawnsley (2011) p.99

${ }^{379}$ Humphreys, James (2005) “The Iraq Dossier and the Meaning of Spin” Parliamentary Affairs vol.58:1, January 2005, p.158-159

${ }^{380}$ Humphreys, p.156
} 
- Hussein's human rights record to add another moral element to remove Hussein. 382

The dossier presented Saddam as a threat even though there was no evidence that Iraq was an immediate threat at all. ${ }^{383}$ Originally Alistair Campbell was not impressed with the earlier first draft of the dossier, he did not think it made a clear case that Saddam could attack at any minute, while Blair thought that the dossier did not focus enough on human rights. ${ }^{384}$

A second dossier was released in February 2013, this was later known as the dodgy dossier, which was based from a 12 year old $\mathrm{PhD}$ thesis which was found on the internet and then reworded with stronger language. ${ }^{385}$ Rawnsley described it as a piece of propaganda that was developed by 'the Campbell spin machine', it was 'given haphazardly to a few journalists on this basis that it would be a good new story for the next day.'386 O'Shaugnessy noted that:

The [thesis] was not simply plagiarised, it was also altered. For example, the phrase 'helping opposition groups' was changed to 'supporting terrorist organisations', and 'monitoring foreign embassies' became 'spying on foreign embassies. '387

Blair passed off this information as 'further intelligence' to support the case for war. 388

\footnotetext{
${ }^{381}$ Humphreys, p. 157

${ }^{382}$ Humphreys, p.160

383 Rawnsley (2011), p.119

${ }^{384}$ Anthony Seldon(2004) Blair, p.582

385 Rawnsley (2011), p.146

386 Rawnsley (2011), p.146

${ }^{387}$ O'Shaugnessy p.310

388 Rawnsley (2011), p.146
} 
Gould's focus groups suggested that the 'sales-oriented' approach to the war was effective by convincing people that Hussein was a threat. In the lead up to the war, focus groups revealed that people had a 'very high level of personal anxiety, insecurity and vulnerability. They felt a threat to Britain, to themselves and to their families was real.'389 Immediately before the outbreak of war, focus groups became more supportive, and they took 'comfort in [Blair's] strength and conviction. ${ }^{390}$ When the war began there was 'a strong hardening of support towards the government, if also a sense of domestic neglect.'391

At the conclusion of the war focus groups shifted again. Groups were 'insistent that [Blair] refocus on domestic issues immediately'392. A focus group in North London showed that:

The dominant mood in this group was frustration that they do not feel he is prioritising their needs. Iraq, asylum seekers and benefit cheats were getting preferential treatment at the expense of hard-working families. But still 'a high level of response for [Blair]. ${ }^{393}$

There was opposition to the war with massive street protests in London. Robin Cook, Blair's Foreign Secretary in his first term resigned from the government. There was a massive protest in London, with 750,000 demonstrators taking part (according to police reports) or two million demonstrators taking part (according to the organisers). ${ }^{394}$

\footnotetext{
${ }^{389}$ Gould (2011), p.459

${ }^{390}$ Gould (2011), p.460

${ }^{391}$ Gould (2011), p.460

${ }^{392}$ Gould (2011), p.460

${ }^{393}$ Gould (2011), p.461

394 “'Million' march against Iraq War”, (2003), BBC News, Accessed 23 February 2014, <news.bbc.co.uk/2/hi/2765041.stm>
} 


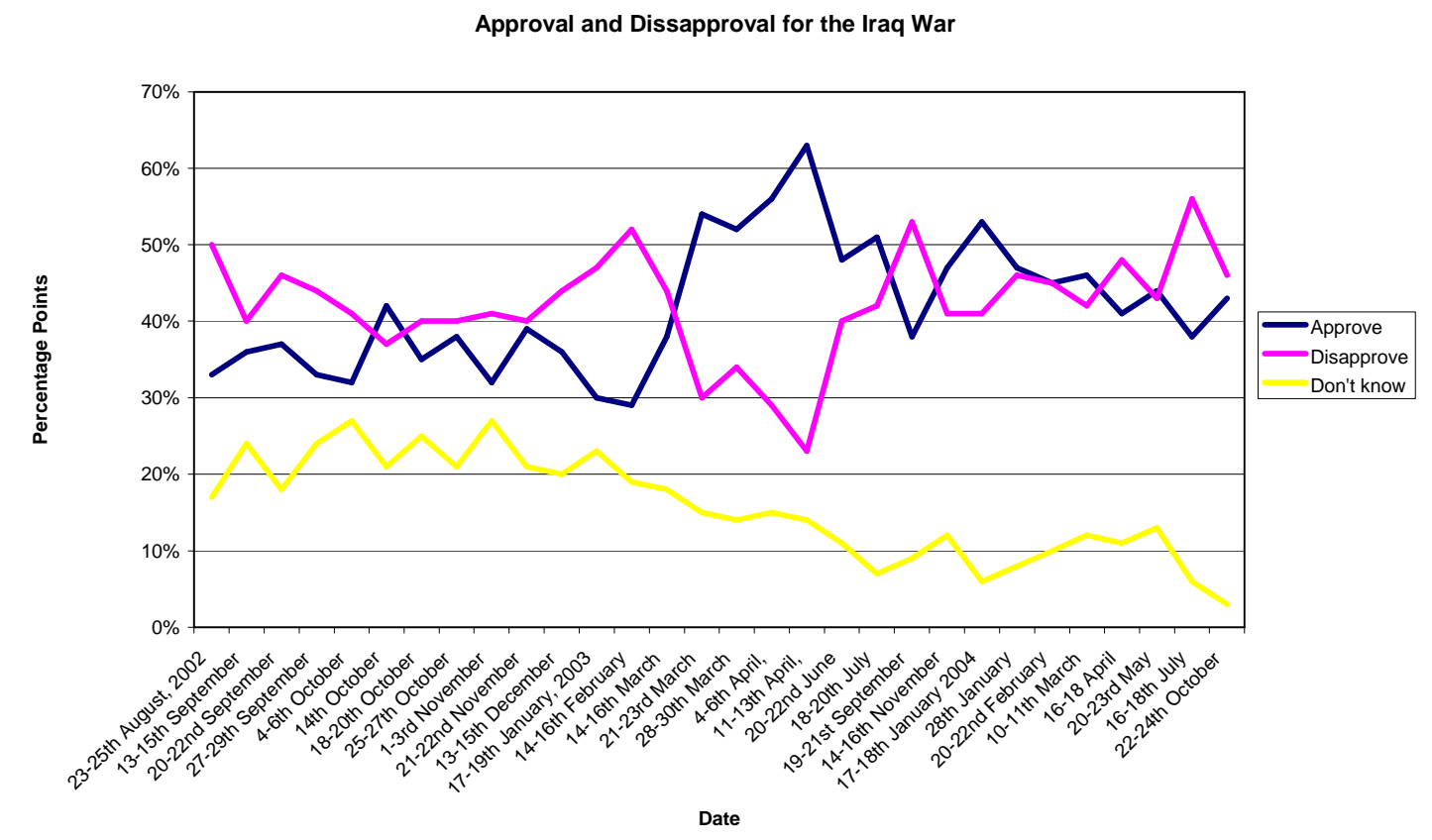

The above graph shows that disapproval to the war was higher than approval for the war. However, more people supported the war when forces were actually deployed and disapprove fell. As the war continued disapproval increased.

There was a sale-oriented approached to the war in Iraq at this time. The government made considerable effort to convince the public to support the war, this was done through the publication of the dossiers and a narrative that Iraq had WMDs. Gould's focus groups suggested that there were concerns about Iraq.

\section{$\underline{\text { Shift in Blair's reputation }}$}

Damage to New Labour's primary brand agent and the product itself took place after the invasion of Iraq. In May 2003, BBC journalist Andrew Gilligan alleged that the government had 'sexed up' the dossier by making false claims that Iraq could deploy WMDs in forty-five minutes, this ultimately led to the suicide of David Kelly, the government scientist who leaked this information to Gilligan. In 
reaction to Kelly's death, Blair set up the Hutton Inquiry. ${ }^{395}$ Hutton's report gave the appearance that the government had an 'obsession with process rather than policy, the cynical media manipulation, the ruthless brutality - and, with all that, a notable lack of success achieving his objective. ${ }^{396}$

The failure to find WMDs during the war had consequences on Blair and New Labour. Gould noted that there was a change in the mood in his focus groups once it was established that there was no WMDs in Iraq, people 'suspect[ed] that [Blair] misled them to ensure the legitimacy of the war.'397 There were also concerns that Blair would 'imitate Thatcher's pattern of turning from a strong visionary leader to an out of touch dictator.'398

Gould observed that there was a shift in public opinion once it was discovered that there were no WMD in Iraq: 'the political landscape after the war changed. The public were less trusting, more sceptical of politicians, and perhaps above all felt a sense of powerlessness in a world that was clearly subject to global forces that nation states could scarcely control.'399 Gould's observation about global forces does present a limitation to political marketing. Nation states are interdependent and emerging forces such as the global war on terror mean that political products, like Blair, get side tracked from their relationship with the political market to focus on international situations.

Rawnsley noted that there was a popular view that 'the Prime Minister had lied his way into the war. As countless banners, placards, T-shirts and web posts had it, he was a 'Bliar'. Even some who were originally supporters of the war came to the conclusion that they were manipulated by a mendacious Prime Minister.' ${ }^{400}$

\footnotetext{
${ }^{395}$ Seldon (2004), p.584

${ }^{396}$ Geoffrey Wheatcroft (2004) 'The Tragedy of Tony Blair,' Atlantic Monthly, August 2004 p.56

${ }^{397}$ Gould (2011), p.461

${ }^{398}$ Gould (2011), p.461

${ }^{399}$ Gould (2011), p.462

${ }^{400}$ Rawnsley (2011), p.120
} 
Rawnsley added that he believed that Blair did 'genuinely believe that the Iraqi dictator was intent on possessing the most horrific weapons.' 401

Even though Blair might have believed he was doing the right thing by invading Iraq, New Labour's sales-oriented approach to convincing the British public to support the invasion ultimately failed because the central argument that Iraq had WMDs turned out to be false. As a result of this misconception Blair became a liability to New Labour and there was considerable effort made in the lead up to the 2005 election to repair Blair's reputation (discussed in the Brand Narrative section of this chapter). Gould's focus groups showed that people wanted a government that delivered on domestic issues.

\subsection{Positioning}

As with the previous cycle New Labour was still the market-leader in the political market. Its strategy was to defend its market position from other challengers in the political market. This section looks at the 2005 election and how New Labour maintained its market-lead. Then this section examines how David Cameron, as the new Conservative Party leader managed to shift the Conservative towards a more competitive position to become market leader.

\section{The 2005 Election}

New Labour won the 2005 election. However, its vote decreased from 40.7 per cent in 2001 to 35.2 per cent. Under first past the post this gave the party 55.2 per cent of the seats in the House of Commons. Downing Street staffer Matthew Taylor stated that '[Labour] didn't win the 2005 election because the people loved us, we won the 2005 election because people were willing to tolerate us and they didn't really fancy the look of the Tory party. ${ }^{4}{ }^{402}$ But since New Labour won the election, it maintained its position as market leader.

\footnotetext{
${ }^{401}$ Gould (2011), p.460

${ }^{402}$ Quoted in Rawnsley (2011), p.319
} 
In this part of the cycle, the challenger did manager to take back some ground from the market leader. The Conservative opposition was initially weak under Iain Duncan Smith between 2001 and 2003, but his successor Michael Howard managed to take back some ground at the 2005 election.

During the 2005 election the Conservatives as the challenger to the marketleader were able to win back support on some key issues. As stated in the previous chapter, in 2001 the Conservatives tried to win an election based in Britain's role in the European Union. In this election, the Conservatives gained leads in traditional right-wing issues. Gould's pre-election focus groups showed that 'Labour was ahead on the economy, education and the NHS, but only by relatively small margins ( 5 to 8 per cent); the Conservatives were ahead on asylum (by 17 per cent), crime and Europe.'403 Gould commented that 'the Conservative lead on these traditional right-wing issues reduced them into fighting a right-wing, populist asylum campaign, which was a mistake. This got them heard but would never get them a victory.'404

This implies that as the challenger in the 2005 election, the Conservatives did not take the market-leader head-on, it instead focused on winning back right leaning supports who in previous elections did not vote, or voted for more rightwing parties such as the British National Party. As Blair observed, between 2001 and 2005 there was a four per cent swing to the Liberal Democrats, yet the Conservatives did not gain any significant swing, to New Labour 'this was...a classic protest vote, easily recoverable in a third term in time for a fourth-term bid, provided we did not lose the core New Labour support that had stuck with us. ${ }^{405}$ In political marketing terms, and Blair's analysis, the 2005 election was a swing away from the market-leader, to a 'follower' party, the Liberal Democrats.

\footnotetext{
${ }^{403}$ Gould (2011), p.472

${ }^{404}$ Gould (2011), pp.472-3

${ }^{405}$ Blair (2011), p.522
} 


\section{David Cameron}

In late 2005, David Cameron became the leader of the Conservatives. Cameron, like Blair was when he became Labour Leader in 1994, was youthful, dynamic and fresh. In one of his first major speeches as leader Cameron stated that:

Tony Blair's victory in that [1997] election created a problem for the Conservative Party. It was not the same sort of problem that Old Labour had faced. It was not a problem that arose out of a failure of ideas. It was, on the contrary, a problem that arose from the triumph of our ideas. There was in truth nothing fundamentally new about the New Labour analysis except that the party offering it was Labour. ${ }^{406}$

Rawnsley observed that Cameron took an similar approach transforming the Conservatives to what Blair did to Labour, Cameron stated that "What I want to do with the Conservative Party is get it into the mainstream of British politics.'407 Cameron also stated 'I'm not a deeply ideological person. I'm a practical person and pragmatic.' 408 Rawnsley also observed that 'the Cameron generation of Tories were mesmerised by Blair. He had dominated the formative years of their political lives....They regarded the Prime Minister with much more respect and awe than did many in the Labour Party.' 409

From late-2005 the challenger in the Political Market had changed leaders to someone who was more determined to challenge the market-leader head on. To do this David Cameron learnt from the successes of New Labour similar to the way the Blair learnt from the successes of Thatcher in the 1980s.

\footnotetext{
${ }^{406}$ David Cameron (2006) 'Modern Conservatism,' Conservative Party Website, Accessed 25 June 2006 <www.conservatives.com/tile.do?def=news.story.page\&obj_id=127560\&speeches=1>

${ }^{407}$ Quoted in Rawnsley (2011), p.344

${ }^{408}$ Quoted in Rawnsley (2011), p.345

${ }^{409}$ Rawnsley (2011), p.345
} 


\subsection{Brand Narrative}

This section examines at New Labour's brand narrative during this part of the political cycle, focusing on two parts. Firstly, I add to my argument in the previous chapter that New Labour's narrative was created through the use of symbolism. Secondly, the Blair brand and narrative was damaged during this part of the cycle and in the lead-up to the 2005 election, so New Labour did place considerable attention to improve his image.

\section{Continued use of symbolism}

Symbolic government continued in this part of the cycle. O'Shaughnessy described symbolic government as governments that 'campaign permanently, and what is critical to them is the appearance of momentum. Symbolic government is also a government by narrative - small narratives by which governments account for their daily work, and the meta-narratives, the big themes that lend their many activities coherence and give them direction.' ${ }^{410}$ For example, in order to tackle the problem with crime, the Home Secretary, David Blunkett launched numerous initiatives to bring down the crime rate:

- June 2001: $£ 15 \mathrm{~m}$ to drive crime out of shopping centres.

- July 2001: a task force to protect children on the internet.

- September 2001: online campaign to cut car crime.

- October 2001: extending the use of anti-social behaviour orders and top firm sign-up to hi-tech drive to cut crime.

- December 2001: national rethinking crime and punishment initiative.

- February 2002: security boost for 3,000 shops in deprived areas.

- March 2002: further extension of anti-social behaviour orders; new guidelines for tackling drug dealers on housing estates; action on street crime through robbery reduction initiatives;

${ }^{410}$ O’Shaughnessy (2003), p.299 
10 Downing Street crime summit; new advisory panel for victims.

- April 2002: video identification parades in robbery hot spot areas. ${ }^{411}$.

O'Shaughnessy's article suggested that New Labour in government was a symbolic government, it was a government of intention rather than delivery. It is easier to sell intentions and initiatives rather than delivering them. As O'Shaughnessy stated: 'Initiatives fill a role in a symbolic state. They give the appearance of dynamism, a riposte to critics who decry official inactivity.' ${ }^{412}$ O'Shaughnessy does make a cynical assessment of New Labour implying that it was too focused on its perception of delivery rather than actual delivery. While it is fair to say from O'Shaunessey's research that the government did focus more on its intention to deliver rather than actual delivery, in an environment where delivery was difficult due to the relationship between Blair and Brown, and other restraints within the public sector, it is easy to see why it focused on incentives. As Lees-Marshment stated, even when a government delivers improvements, voters do not always appreciate it, ${ }^{413}$ an ongoing narrative of incremental improvements, initiatives, task forces may be an ideal way for a government to communicate.

\section{$\underline{\text { Re-Connecting Blair }}$}

Using Vincent's brand narrative analysis, like Clinton, Blair moved away 'from the sacred beliefs that gave his campaign its brand foundation.'414 Over time with war, and the lack of delivery Blair did move away from those 'sacred beliefs' that got him elected to office in 1997.

According to Gould in late 2003, when Blair was starting to wonder whether or not he should depart as leader, polling showed 'there were doubts about trust

\footnotetext{
${ }^{411}$ O’Shaughnessy (2003), p.304

412 O'Shaughnessy (2003), p.304

${ }^{413}$ Lees-Marshment (2009), p.206

${ }^{414}$ Vincent, p.286
} 
and delivery, and increased concern with asylum and immigration. War was not at the forefront of public concern but had clearly affected the mood. ${ }^{415}$ Gould's focus groups observed that there was no desire for Blair to go; instead the electorate wanted him to re-engage.

A new brand narrative was created that suggested that Blair has misled the British public in order to get their support for the Iraq War. In the lead up to the 2005 election, effort was made to reconnect Blair with political consumers with the recruitment of Promise, a consultancy firm that specialised in brand building. Promises' brief was to 'reconnect' Blair to the electorate. ${ }^{416}$

In letters to Blair, Promise identified three key themes and phrases from its research:

Theme One: You left me

- 'You should have come home' [In response to the Boxing Day Tsunami].

- 'You should put our people first.'

- 'Your country needed you.'

- 'All the promises you made that never came true.'

The underlying emotion behind these phrases are 'abandonment and unimportant' and the key desire is to 'get back in touch'. ${ }^{417}$

Theme Two: Too big for your boots

- 'A President with Cherie.'

- 'Globe-trotting holiday maker.'

- 'Celebrity hero worship.'

\footnotetext{
${ }^{415}$ Gould (2012), p.466

${ }^{416}$ Scammell (2007), p.182

${ }^{417}$ Roy Langmaid, Charles Trevail and Ben Heyman (2006) 'Reconnecting the Prime Minister' Research 2006 Conference Paper, Accessed 15 March 2014,

<www.promisecorp.com/documents/Reconnecting_the_Prime_Minister.pdf> p.12
} 
The underlying emotion is that Blair was too focused on his self-importance and to get back in touch he needs to 'get back to basics'. ${ }^{418}$

\section{Theme Three: Reflect and Change}

- 'Take time to think.'

- 'how foolish you have been.'

The underlying tone is that Blair was out of control and needed to reflect 'are you still the bloke we elected or have you moved on to bigger things?'419

Promise's research showed that by 2005 the New Labour Brand was under threat because of Iraq and the media attacks. It argued that Blair and New Labour were at a point where "everything that they did was being distorted by this negative brand lens. ${ }^{\prime} 20$ The research also demonstrated that Blair was so central to the New Labour brand that his negative perceptions had 'reached the very core of the brand.' 421

Promise identified that:

- 'The New Labour brand - personified by Tony Blair - had stopped listening.'

- 'The brand had become for too reliant on the figurehead - despite his failings, without Blair, New Labour seemed lightweight.'

- 'The New Labour brand was hollow, many described this a the triumph of spin over substance. ${ }^{4} 22$

- There was 'weakness of the brand - Blair didn't listen over Iraq, media and infighting with Brown.'423

\footnotetext{
${ }^{418}$ Langmaid, Trevail and Heyman, p.12

${ }^{419}$ Langmaid, Trevail and Heyman, p.12

${ }^{420}$ Langmaid, Trevail and Heyman, p.17

${ }^{421}$ Langmaid, Trevail and Heyman, p.17

${ }^{422}$ Langmaid, Trevail and Heyman, p.18

${ }^{423}$ Langmaid, Trevail and Heyman, p.19
} 
In the lead up to the 2005 election campaign, Blair took on the theme of "reflect and change' at Labour's 2005 Spring Conference with these certain phrases:

- Connecting with people about Iraq - 'I understand why some people feel angry - not just over Iraq but many of the difficult decisions we have made.' 424

- $\quad$ Showing growth as a leader 'And, as ever, a lot of it is about me.' ${ }^{425}$

- Re-engaging with the relationship with political consumers 'I think a lot about my relationship with the country....and it's not a bad idea to think of it in terms of it being like any relationship: you, the British people and me, the person you chose as your Prime Minister.' ${ }^{426}$

- Reflection on the slow pace of delivery, but notes improvements have been

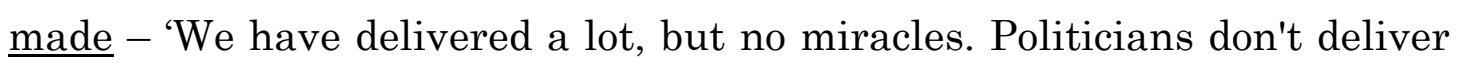
miracles. And life is not about euphoric moments. It's about steady change for the better. So after the euphoria, came the steady hard slog of decisionmaking and delivery.' 427

- Reflecting that there are other relationships with others in a political market - 'And the events that tested me. And the media mood turning, and friends sometimes being lost as the big decisions mounted, and the thousand little things that irritate and grate, and then all of a sudden there you are, the British people, thinking: you're not listening and I

\footnotetext{
${ }^{424}$ Tony Blair (2005) 'Spring Conference Speech,' The Guardian Accessed 28 March 2014 <www.theguardian.com/politics/2005/feb/14/labour.speeches>

${ }^{425}$ Tony Blair (2005) 'Spring Conference Speech,' The Guardian Accessed 28 March 2014 <www.theguardian.com/politics/2005/feb/14/labour.speeches>

${ }^{426}$ Tony Blair (2005) 'Spring Conference Speech,' The Guardian Accessed 28 March 2014 <www.theguardian.com/politics/2005/feb/14/labour.speeches>

${ }^{427}$ Tony Blair (2005) 'Spring Conference Speech,' The Guardian Accessed 28 March 2014 <www.theguardian.com/politics/2005/feb/14/labour.speeches>
} 
think: you're not hearing me. And before you know it you raise your voice. I raise mine. Some of you throw a bit of crockery.' ${ }^{428}$

- Giving the British people a choice when with the election - 'And now you, the British people, have to sit down and decide whether you want the relationship to continue. If you decide you want Mr Howard, that is your choice. ${ }^{429}$

Over the course of the 2005 campaign the party used a 'masochism strategy' where Blair took part in interviews conducted by aggressive interviewers and contained audiences to question him, 'the strategy, with its underlying analogy of a rocky marriage, provoked considerable press interest and no little contempt as the prime minister was subjected to some humbling encounters. ${ }^{430}$ Rawnsley noted that Iraq was problematic for Labour, in an interview with the Observer, Blair acknowledged that 'there is a question about the judgement of the decision,' he 'simply asked people to appreciate the dilemma that faced him at the time.' ${ }^{431}$

There was a market-oriented approach to the way New Labour tried to reconnect Blair to the electorate. Promise's research did identify Blair's weaknesses, in the eyes of the political consumer, and then the party made an effort during 2005 election to reengage with the electorate.

\subsection{Brand agent}

During the maturity stage of the product life-cycle, Blair was in decline as the Primary Brand Agent. As stated above, Promise's research showed that due to the Iraq War Blair had become so damaged that it also impacted on the greater New Labour Brand. Even though the 2005 election was a victory for the Labour Party, it was a set-back for Blair. It showed that after taking part in an

\footnotetext{
${ }^{428}$ Tony Blair (2005) 'Spring Conference Speech,' The Guardian Accessed 28 March 2014 <www.theguardian.com/politics/2005/feb/14/labour.speeches>

${ }^{429}$ Tony Blair (2005) 'Spring Conference Speech,' The Guardian Accessed 28 March 2014

<www.theguardian.com/politics/2005/feb/14/labour.speeches>

${ }^{430}$ Scammell (2007), p.186

${ }^{431}$ Rawnsley (2011), p.306
} 
unpopular war and his long time in office, 'his personal authority, which rested so heavily on the ability to win votes, was damaged by the results.' ${ }^{432}$ On top of that between 2006 and 2007 Blair was further tainted in the 'cash for honours' scandal where it was revealed that four individuals who loaned large amounts of money to the Labour Party, were nominated for peerages by Blair. ${ }^{433}$ The scandal dragged on and was subjected to a police investigation, hurting Blair.

Blair stated that his final years in office (2005-2007) were a challenge because:

Gordon [Brown] was in a perpetual state of machination; the anti-Blair media (most of it) had given up any pretence at objectivity; Iraq teetered on the brink; and when all else failed, there was a police inquiry into me and my staff that very nearly toppled the government without a charge ever being laid. ${ }^{434}$

Blair's authority was further diminished when he announced his intention of leaving Number 10 about a year before departure. In an interview for Australian Television Blair said 'It was an unusual thing for me to say, but people kept asking me the question so I decided to answer it. Maybe it was a mistake. ${ }^{435}$

The below MORI opinion polls for this period suggested that both the Government and Blair were unpopular.

\footnotetext{
${ }^{432}$ Rawnsley (2011), p.319

433 'Cash-for-Honours timeline'(2007) The Guardian, Accessed March 142014

<www.theguardian.com/politics/2007/oct/11/partyfunding.uk>

${ }^{434}$ Blair (2011), p.573

${ }^{435}$ Quoted in Rawnsley (2011), p.364
} 
Figure 6.3 Satisfaction for Blair and the Government 2006 - June $2007^{436}$

\begin{tabular}{|c|c|c|c|c|}
\hline & $\begin{array}{l}\text { Govt } \\
\text { Satisfaction }\end{array}$ & $\begin{array}{l}\text { Govt } \\
\text { Dissatisfaction }\end{array}$ & $\begin{array}{l}\text { Blair } \\
\text { Satisfaction }\end{array}$ & $\begin{array}{l}\text { Blair } \\
\text { Dissatisfaction }\end{array}$ \\
\hline $\begin{array}{l}\text { 9-23 January } \\
2006\end{array}$ & 32 & 60 & 36 & 57 \\
\hline $\begin{array}{l}16-20 \text { February } \\
2006\end{array}$ & 28 & 60 & 31 & 60 \\
\hline 16-21 March 2006 & 27 & 65 & 31 & 62 \\
\hline $\begin{array}{l}27 \text { April - } 2 \text { May } \\
2006\end{array}$ & 22 & 68 & 29 & 64 \\
\hline 25-30 May 2006 & 22 & 69 & 26 & 67 \\
\hline 22-26 June 2006 & 27 & 64 & 32 & 60 \\
\hline 20-24 July 2006 & 23 & 68 & 23 & 67 \\
\hline $\begin{array}{l}31 \text { August- } 6 \\
\text { September } 2006\end{array}$ & 24 & 67 & 26 & 66 \\
\hline $\begin{array}{l}12-16 \text { October } \\
2006\end{array}$ & 27 & 64 & 32 & 60 \\
\hline $\begin{array}{l}\text { 9-14 November } \\
2006\end{array}$ & 22 & 69 & 27 & 65 \\
\hline $\begin{array}{l}\text { 7-12 December } \\
2006\end{array}$ & 26 & 64 & 30 & 64 \\
\hline $\begin{array}{l}\text { 19-29 January } \\
2007\end{array}$ & 24 & 69 & 25 & 68 \\
\hline 19-25 April 2007 & 27 & 66 & 28 & 66 \\
\hline 17-22 May 2007 & 30 & 60 & 35 & 57 \\
\hline
\end{tabular}

\footnotetext{
436 'Political Monitor: Satisfaction Ratings 1997-Present' (2014), Ipsos MORI website, Accessed 3 April 2014 <www.ipsos-mori.com/researchpublications/researcharchive/poll.aspx?oItemID=88\&view=wide>
} 
Using Vincent's Brand Narrative model, the brand narrative and the brand agent was no longer useful for the brand. From 2007, New Labour changed its primary brand agent when Gordon Brown became Prime Minister.

\subsection{Summary}

New Labour in the maturity cycle of the product life-cycle is summarised as:

Product

- Elements of a Market-Orientation.

- Sales-Orientation becomes more dominant.

- Division between key players in the government.

Position

- New Labour as the market leader defends its market share but does lose some of it.

- The challenger, the Conservatives, was still weak at the beginning but by the end of the cycle it started to adopt the market-leader's ideas.

Brand narratives

- Symbolism was used to show the brand narrative.

- Attention was given to reconnecting Blair to the electorate after the Iraq war.

Brand agent

- Brand agent becomes a liability to the brand.

- A new Primary Brand agent (Brown emerges). 


\section{Decline}

This chapter analyses the decline of New Labour in the product life-cycle model. For this chapter, I have identified the decline period of New Labour as between October 2007, when Brown's credibility fell due to the aborted September 2007 election, and May 2010 when New Labour was defeated at the general election. ${ }^{437}$

Butler and Collins described the decline period as 'when sales fall off and profits drop.' ${ }^{438}$ According to Rajagopal and Sanchez's model, in the decline period a brand is redesigning itself, it is preparing for entry into the market, it modifies its weak features and educates consumers on its new features as it is preparing to re-enter the market. ${ }^{439}$ In terms of political marketing, parties go into decline when they are on the path to electoral defeat. Also, as illustrated with the Labour Party after it left office in 1979, decline can continue in opposition, until a new product is credible enough to be reintroduced into the political market. Rajagopal and Sanchez also suggested that a brand in decline may attempt to launch new features. In political marketing terms, this is where a political product does successful rejuvenate it may return to the maturity stage. Unlike Rajagopal and Sanchez's analysis a political party cannot simply be reintroduced into the market, it needs to leave government and spend time in opposition.

Timothy Heppell identified six symptoms of degeneration in governments, political products in the decline cycle experience these symptoms. The symptoms are:

- Government being questioned about its competence (especially around the managing the economy).

- Credibility of the leadership being questioned.

- Ideological divisions and suspicions within the party.

\footnotetext{
${ }^{437}$ Please note, for this thesis, I will not discuss whether or the Labour product continued to decline under the leadership of Harriet Harman (acting leader) or Ed Miliband (current leader).

${ }^{438}$ Kotler and Armstrong (2012), p.273

${ }^{439}$ Rajagopal and Sanchez, (2004), pp.243-244
} 
- Elements of corruption, sleaze or abuse of power.

- Government haunted by past mistakes.

- Regenerated and credible opposition party has emerged. ${ }^{440}$

This chapter shows that New Labour in decline suffered from all of these symptoms. I hypothesise that it is possible for a party in decline to successfully rejuvenate and move back into the maturity stage. But once a party starts to decline momentum builds about the party's eventual defeat it is difficult to successfully rejuvenate and prevent removal from office. Like the previous chapters, this chapter discusses New Labour's product, position, brand narrative and brand agent in the decline phase of the life-cycle model. But firstly I outline how New Labour went from the maturity to the decline phase.

\subsection{From Maturity to Decline}

New Labour made the shift from the maturity cycle to the decline cycle between September and October 2007 when Brown aborted the so-called election of 2007. The New Labour product rejuvenated itself in 2007 when the leadership of the party and the government was transferred from Blair to Brown. During the first few months of Brown's premiership the party was still in the maturity cycle because it appeared that Brown's succession had successfully rejuvenated New Labour. In his first few months in office, Brown was tested with a small terrorist incident, by a natural disaster and by a bank run on the Northern Rock bank. Brown adopted the role of a 'father of the nation' who worked well under pressure.

In July 2007, private polling suggested that Labour was eight points ahead of the Conservatives and that Brown was perceived as a stronger leader than David Cameron. Members of his inner circle suggested that Brown call an autumn

\footnotetext{
${ }^{440}$ Timothy Heppell (2008) “The Degenerative Tendencies of Long-Serving Governments...1963 ...1996...2008?” Parliamentary Affairs, vol.61:4, p.580
} 
election. ${ }^{441}$ Not only would an early election give Brown his own mandate it would also destabilise the Conservatives who were not ready for an election. ${ }^{442}$ Brown himself was divided over calling an election, but he liked the idea of having his own mandate. However, he had waited ten years to become prime minister and he did not want risk throwing that away after three months. ${ }^{443}$ An internal poll suggested that Labour would win with a majority of between 35-45 seats. ${ }^{444}$

During Labour's conference there was speculation that an election would be called, Brown did nothing to dampen the speculation. The press began to speculate that an election was coming with headlines such as 'Election fever rages as Brown's lead grows' and 'Go for it Gordon.' ${ }^{\prime 45}$ At the time, the media was in praise of Brown's strength while contemptuous about Cameron's abilities. 446 Gould was called in to work with Saatchi and Saatchi on the adverting campaign which was going to focus on the slogan of 'Not flash just Gordon' (which was a word play on the superhero Flash Gordon). ${ }^{447}$ There were concerns, however, that there was no policy to back up this campaign. 448 Weeks later, during the Conservative's conference, Brown tried to upstage Cameron by making a surprise visit to Iraq. His aim was to appear like a statesman while the opposition was divided at its conference. Instead it made him look like a political opportunist using the troops to upstage the opposition at its conference. ${ }^{449}$

Brown dithered on whether or not he was going to call an election and in early October 2007 he decided not to call an election. The polls were starting to shift away from Labour and the earliest possible election would have been in November, as Britain started moving into winter. With the election of 2007 not taking place a negative perception of Gordon Brown set in which he was never

\footnotetext{
${ }^{441}$ Rawnsley (2011), p.496

${ }^{442}$ Rawnsley (2011), p.498

${ }^{443}$ Rawnsley (2011), p.499

${ }^{444}$ Rawnsley (2011), p.500

${ }^{445}$ Quoted in Rawnsley (2011), p.501

${ }^{446}$ Rawnsley (2011), p.501

${ }^{447}$ Gould (2011), p.504

${ }^{448}$ Gould (2011), p.504

${ }^{449}$ Rawnsley (2011), p.506
} 
able to shake. Gould stated that on becoming prime minister people were unsure about Brown in the role and that there were two opposing views about him, 'the negative was uncharismatic, lacking leadership skills: a good Chancellor but a bad Prime Minister. The positive was a strong man, his own person, a leader who had started off well as Prime Minister.' 450 Gould stated that by not holding the election in 2007 the negative view of him prevailed. ${ }^{451}$ Gould further argued that:

If [Brown] had called the election and won, even by a small majority, he would have been transformed, the survivor of a hugely difficult rite of leadership passage, the winner of a fourth term. The image of him, and the reality too, would have changed. 452

Cameron mocked him saying that 'He's the first Prime Minister in history to flunk an election cos he thought he was going to win it!'453 Likewise journalists 'taunted Brown to admit that he had run away from the country because of the turn in the polls. They were mocking to his face when he claimed that he was so keen to 'deliver my vision' that he would have called off the election even if his pollsters had told him he would have won with a majority of $100 .{ }^{3454}$

Despite the hype about the election, Brown denied political consumers an opportunity to give its view on Brown's New Labour. On reflection, this was the turning point in Brown's leadership, the negative perceptions of a poor leader who dithered set in for the rest of his term in office. Using the product life-cycle, I pinpoint this as the moment where New Labour went from the maturity stage to the decline stage. Compared to the transition from growth to maturity phases, after 9/11 when there was a change of tone in the government, the New Labour transition from maturity to decline started from a defining event.

\footnotetext{
${ }^{450}$ Gould (2011), p.505

${ }^{451}$ Gould (2011), p.505

${ }^{452}$ Gould (2011), p.505

${ }^{453}$ Quoted from Rawnsley (2011), p.513

${ }^{454}$ Rawnsley (2011), p.513
} 


\subsection{Product}

In this section I examine the New Labour product during the decline stage. I focus on three aspects of the product. First, there were questions about the legitimacy of Brown as party leader. Secondly, I examine the policies of Brown's New Labour. Finally I look at the scandals and divisions that appeared during this cycle that damaged the product's reputation.

\section{Brown's Legitimacy}

One criticism of Brown from political consumers was that he was not a legitimate leader. He became leader about two years into a parliamentary term. By winning the 2005 election, Blair was seen as the leader that had the backing of political consumers. After Blair stood down, Brown faced no challengers when he stood for the leadership of the party. Likewise, as outlined above, by aborting the autumn 2007 election, when expectations had been set, there was a perception that Brown denied people the right to give their verdict on his leadership. In political marketing terms, he did not have a dialogue with political consumers, and they felt left out because they were not involved.

Even with a challenger in the 2007 Labour Party leadership ballot, it was likely that Brown would have won the leadership. However, a contest would have given Brown an opportunity to define his vision for the party and the government. At the beginning, when Labour was in opposition, New Labour would use battles within the party to define itself, such as the abolition of clause four, and Brown missed an opportunity to replicate this type of manoeuvre. Political consumers might have felt more at ease about Brown's legitimacy after such a contest.

Before Blair stood down, Gould wrote a letter to Brown and Blair warning that 'The absolutely key period is the new leader's first few months. The window of opportunity for the next leader is huge....A top-down handover will feel undemocratic and undermine the chance of renewal. There needs to be a rite of 
passage into the new leadership.'455 Gould's focus groups also showed that people felt that Blair should not have been forced out against his will, as he was elected by the people in $2005 .{ }^{456}$ This shows that legitimacy is important to political consumers, and when a party changes its leader mid-term there can be a backlash. After Brown became Prime Minister, Gould noted in his focus groups that he had 'lost count of the number of times voters said in focus groups that he was unelected, that he did not have the right to the job.' ${ }^{457}$

The above example shows that political parties that want to rejuvenate in the maturity or decline stages by changing their leader need to be careful about how to approach this. This issue could have been controlled better by at least a Labour leadership election or at best an early general election. The way the previous leader departs is an important factor, if there is a perception that he/she was forced out against their will, this may also shape the minds of political consumers.

\section{Production Orientation in Policy}

An assessment by Seldon and Lodge found that Brown had limited policy achievements, apart from his policies to combat the Global Financial Crisis (GFC). They argue that he made small improvements in health by appointing a surgeon as one of the health ministers, but failed to take any real big decisions. School improvement stalled. He began to reverse some of the Blairite approaches to law and order, not making it a priority until before the 2010 election. ${ }^{458}$ This section focuses on New Labour's approach to the GFC and its shift away from New Labour policies in the lead up to the 2010 election.

\footnotetext{
${ }^{455}$ Gould (2011), p.493

${ }^{456}$ Gould (2011), p.497

${ }^{457}$ Gould (2011), p.501

${ }^{458}$ Anthony Seldon and Guy Lodge (2011), Brown at 10, Biteback Publishing, London, p.xxix
} 


\section{The $G F C$}

In response to the GFC of 2007-08, where large financial institutions collapsed and governments intervened by bailing them out, Brown took on a world leadership role by encouraging governments to take an interventionist approach to their own economies to prevent a greater world recession. 459 One of Brown's biggest selling points as Chancellor was that he was able to put an end to 'boom and bust' economics and this argument collapsed with the fall in the British economy. ${ }^{460}$ In saving the financial institutions and the British economy Brown 'intervened massively in the economy, thereby throwing its finances deeply into the red.' 461 This was a contrast to Brown the Chancellor who exercised economic prudence. ${ }^{462}$

Aspects of old Labour that political consumers did not like crept back into the government's response to the GFC. By Blair's own analysis, Brown's early approach to the GFC was correct, Brown had 'acted at his best, intellectually rigorous, totally driven, sure in his touch.' ${ }^{463}$ However, as the GFC developed there was a shift away from New Labour's market-orientation to something that resembled old Labour. For example the government increased the highest tax rate to $50 \mathrm{p}$.

Blair's analysis further stated that the Government took an 'Old Labour way out of the financial crisis' by using a 'traditional Keynesian analysis of how to stimulate the economy'. Blair stated that there were halts on key aspects of New Labour halted, public service reform slowed and law and order policies were not as strong as they were earlier. 464 '[New Labour] did 'lose touch', not with 'our roots' but with a public whose anxieties over tax, spending, immigration and

\footnotetext{
${ }^{459}$ Steven Fielding (2010), 'Labour's Campaign: Things Can Only Get...Worse?, Parliamentary Affairs, vol.63:4, p.657

${ }^{460}$ Fielding, p.657

${ }^{461}$ Fielding, p.657

${ }^{462}$ Fielding, p.657

${ }^{463}$ Quoted in Gould (2011), p.xii

${ }^{464}$ Quoted in Gould (2011), p.xii-xiii
} 
crime were precisely the opposite of those on the left criticising New Labour. As a result, we did not seem like the party of the future.' ${ }^{465}$

As Fielding noted, commentators, and especially the Murdoch press, argued that Brown's shift in policies represented the death of New Labour:

In November 2008, the Sun pictured a tombstone on its front page on which was carved 'RIP New Labour.' The accompanying story surveyed 'The life and death of Blair's baby' which had, it claimed, finally succumbed to 'socialism.' 466

Gould stated that the change in tactic made voters nervous about Labour. He argued that at the end, the Government was not a New Labour government because it had slowed down its reform agenda and was too slow to make the shift from a government that was stimulating the economy to a government that was finding ways to cut the deficit. ${ }^{467}$ It had not moved 'early enough to balance a focus on spending with efficiency, reducing waste, and a new conception of the state and how it serves people.'468

Likewise, Rawnsley argued that even though voters generally supported the idea of the wealthy taking on more responsibility for the GFC and recession, it was a 'symbolic retreat from the original New Labour prospectus. [Labour] was back to where they were before Blair won over aspirational voters.' 469

\section{Manifesto}

Relationship marketing is about a relationship of trust between the supplier and consumer. At this stage of the product life-cycle it is fair for political consumers to question New Labour's ability to deliver on its promises. Rawnsley observed that the 2010 election manifesto promised some 'radical reforms to the

\footnotetext{
${ }^{465}$ Quoted in Gould (2011), p.xii-xiii

${ }^{466}$ Fielding, p.657

${ }^{467}$ Gould (2011), p.506

${ }^{468}$ Gould (2011), p.506

${ }^{469}$ Rawnsley (2011), p.642
} 
constitution, the financial sector and public services.' ${ }^{370}$ However, people were right to point out that Labour has been in power for 13 years, why had they not done these reforms in the past. Rawnsley observed that the 'manifesto often read like a list of things they regretted not doing earlier.' ${ }^{471}$ Mandelson's criticism of the manifesto was that it 'seemed to have been road-tested more with Guardian columnists than Philip's groups of voters. ${ }^{472} \mathrm{He}$ also argued that the manifesto lacked a 'coherent or compelling vision for the future that would set pulses racing.' 473

The above example gives an indication that in the decline stage, New Labour shifted its concerns away from the political consumers to a product-oriented party. While at the beginning it did take what was regarded as the right approach towards the GFC, in later failed to understand political consumers concerns about its shift away from New Labour and their anxieties about the increased deficit.

\section{Division and scandal}

During this period the government faced division from amongst Labour MPs, division from other brand agents within the Labour Party. The party and the whole British Parliament was also caught up in the expenses scandal. The strong New Labour product from earlier cycles had shifted towards a party of disunity. Seldon and Lodge noted that the 2005 Parliament, during which Brown was Prime Minister for 60 per cent of the time, proved to be the most rebellious in the post-war era.'474 They noted that the longer the party remained in office 'the more truculent become the backbenches.' 475 They also argue that Brown's made matters worse for himself with his 'often graceless management of Labour MPs'

\footnotetext{
${ }^{470}$ Rawnsley (2011), p.717

${ }^{471}$ Rawnsley (2011), p.717

${ }^{472}$ Mandelson , p.526

${ }^{473}$ Mandelson, p.526

${ }^{474}$ Seldon and Lodge, p. 260

${ }^{475}$ Seldon and Lodge, p.260
} 
which was a contrast to Blair's politeness.'476 Opposition from Labour MPs included opposition to a third runway for Heathrow Airport, part privatising Royal Mail.

As well as a divisive Parliamentary Labour Party, questions were also raised by ministers about Brown's performance. There were three failed leadership coups in autumn 2008, spring 2009 and January 2010. During the spring 2009 attempt Foreign Secretary David Miliband was mentioned as a possible successor to Brown, but at this time he was considered too inexperienced. He had also declined the opportunity to stand against Brown in the 2007 leadership contest. ${ }^{477} \mathrm{He}$ wrote an article in the Guardian that acknowledged the mistakes that New Labour had made in the past as well as the need to adapt to the key policies issues of the day such as energy efficiency and global climate change. ${ }^{478}$

Brown was also the prime minster during the 2009 parliamentary expenses scandal where the expenses of MPs were made public. MPs from all parties in parliament were exposed for making dodgy claims which lead to a number of resignations, de-selections and retirement announcements. Seldon and Lodge described the expenses scandal as the 'biggest parliamentary crisis in Modern British history, when public anger with politicians reach unprecedented heights and public trust in the political system all but collapsed.'479 While Brown was not guilty of expense abuses himself, Seldon and Lodge criticised him for poorly managing the crisis and not providing leadership, which 'diminished his own standing.' 480 They argued that he could have used the crisis to produce a settlement that would have resolved the issue and made progress on the constitutional agenda that he had promised to make progress on. ${ }^{481}$

\footnotetext{
${ }^{476}$ Seldon and Lodge, p. 260

477 Seldon and Lodge, p. 140

${ }^{478}$ David Miliband (2008) 'Against All Odds, We Still Can Win, On a Platform for Change' The

Guardian,Accessed 17 April 2014 <www.theguardian.com/commentisfree/2008/jul/29/davidmiliband.labour>

${ }^{479}$ Seldon and Lodge, p.262-263

${ }^{480}$ Seldon and Lodge, p.263

${ }^{481}$ Seldon and Lodge, p.263
} 
In summary, the New Labour product in decline had issues with the credibility of its leader. Its policies during the GFC represented a shift away from the New Labour model and had elements of a product-orientation. In fairness to Brown he did face a major economic crisis in his premiership, while the New Labour product in the other cycles of the product life-cycle model enjoyed a stronger economy. Likewise Brown also faced a parliamentary expenses scandal that questioned the political market's confidence in all politicians. The unity of the New Labour product in the early parts of the cycle had vanished.

\subsection{Positioning}

In the decline cycle, Labour made the transition from the market leader to the challenger when it lost the 2010 election. The challenger, the Conservatives, was a much stronger challenger to New Labour than it had been previous cycles. The position of market-leader is a defensive position insomuch as it is defending and protecting the support gained in previous elections, so in the decline phase it had lost enough support to return to the status of challenger. As outlined above, the product lost support by shifting back to an 'old' Labour view on economic policy and by having a leader who was unpopular. On the other hand, the Conservatives had lifted its game and was in a position to take Labour's support.

The Conservatives were in a stronger position in this part of the product lifecycle because it had become more disciplined and it had been repositioned in the centre. ${ }^{482}$ It had modelled itself on New Labour in its early days, Mandelson observed that:

Cameron and his team 'strategy sculpted around New Labour precepts: fiscal responsibility; a belief in strong, reformed public services; a commitment to combat poverty among the 'have-nots' as well as to give the 'have-somethings' more in life; toughness on both crime and the causes of crime....Cameron knew where

${ }^{482}$ Rawnsley (2011), p.705 
he needed to locate his party to win. In a series of speeches and advertising campaigns early on in his leadership, he attacked health inequalities to show his commitment to the NHS. He championed environmental issues, not natural Tory territory. ${ }^{483}$

The Conservatives was able to become the market leader. Mandelson also commented that the changes the conservatives made to the party 'did not amount to a fundamental, New Labour-scale shift.' 484 The fact that the 2010 election resulted in a hung parliament does suggest that the changes the Conservatives made was tiny in comparison to the changes that New Labour made between 1994-1997 when the product was being develop.

Like in the introduction stage of the product life-cycle, the Conservatives tried to better Labour on core centrist areas, such as health, education and the economy.

Labour found it difficult to defend its market share during this phase of the cycle; more importantly, the Conservative Party was seen as a better economic manager than Labour in opinion polling. ${ }^{485}$ The below table shows that in the top determining issues such as managing the economy, healthcare, education and asylum, the Conservatives had a lead in the economy, education and asylum. Labour was still stronger in the social issues like healthcare.

Table 7.1. Issue Salience Leading up to the 2010 General Election ${ }^{486}$

Looking ahead to the next General Election, which, if any, issues do you think will be very important to you in helping you decide which party to vote for?

\begin{tabular}{|l|l|}
\hline Managing the Economy & 32 \\
\hline Healthcare & 26 \\
\hline Education & 23 \\
\hline
\end{tabular}

\footnotetext{
${ }^{483}$ Mandelson, p.xxxI

${ }^{484}$ Mandelson, p.523

${ }^{485}$ 'Ipsos MORI March Political Monitor' (2010), Ipsos Mori Website, Accessed 3 April 2014, <www.ipsosmori.com/Assets/Docs/Polls/Mar10\%20Political\%20MonitorTopline_BPOKI.pdf>

${ }^{486}$ 'Ipsos MORI March Political Monitor' (2010), Ipsos Mori Website, Accessed 3 April 2014, <www.ipsosmori.com/Assets/Docs/Polls/Mar10\%20Political\%20MonitorTopline_BPOKI.pdf>
} 


\begin{tabular}{|l|l|}
\hline Asylum and immigration & 14 \\
\hline Taxation & 12 \\
\hline Unemployment & 11 \\
\hline Crime and anti-social behaviour & 8 \\
\hline Benefits & 7 \\
\hline Care for older and disabled people & 7 \\
\hline Pensions & 6 \\
\hline
\end{tabular}

Table 7.2. Issue Identification by Party (2010) 487

Which party do you think has the best policies on.... the Conservatives, Labour, Liberal Democrats or some other party?

\begin{tabular}{|l|l|l|l|}
\hline & Labour & Conservative & Liberal Democrats \\
\hline $\begin{array}{l}\text { Asylum and } \\
\text { Immigration }\end{array}$ & 17 & 28 & 9 \\
\hline $\begin{array}{l}\text { Crime and } \\
\text { Antisocial } \\
\text { behaviour }\end{array}$ & 23 & 33 & 8 \\
\hline Education the & 26 & 29 & 10 \\
\hline $\begin{array}{l}\text { Healthcare } \\
\text { Managing }\end{array}$ & 33 & 24 & 9 \\
\hline Taxation & 25 & 29 & 12 \\
\hline Defence MPs & 13 & 26 & 13 \\
\hline Unemployment & 30 & 29 & 7 \\
\hline Benefits & 30 & 24 & 10 \\
\hline $\begin{array}{l}\text { Reforming } \\
\text { expenses }\end{array}$ & 18 & 24 & 10 \\
\hline Climate change & 15 & 11 & 14 \\
\hline
\end{tabular}

\footnotetext{
${ }^{487}$ 'Ipsos MORI March Political Monitor' (2010), Ipsos Mori Website, Accessed 3 April 2014, <www.ipsosmori.com/Assets/Docs/Polls/Mar10\%20Political\%20MonitorTopline_BPOKI.pdf>
} 


\section{Hung parliament}

The 2010 election resulted in a hung parliament where the Conservatives became the market-leader by winning 306 seats (36.1 per cent of the popular vote) and by forming a coalition government with the Liberal Democrats. Labour won 258 seats (29 per cent) and the Liberal Democrats won 62 seats (23 per cent). The hung parliament gave Labour the option to maintain its status as the market leader, but in a coalition or in a minority government. However, the Conservatives plus the Liberal Democrats had enough seats to form a majority government, while Labour plus Liberal Democrats could only produce a minority government dependent on the support of nationalist parties and other small parties in House of Commons.

If Labour and the Liberal-Democrats had the numbers to form a majority coalition government, this could have been the rejuvenation that New Labour needed to move back into the maturity cycle of the product life-cycle. A coalition of Britain's two progressive parties, or in Collins and Butler's terms, the marketleader and the follower could have been formed. A new Labour leader and the inclusion of the Liberal Democrats could have stopped the decline and brought in renewal. This move could have been bold enough for New Labour to become a government responsive to the political market. Nick Clegg, who was the 'discovery' of the 2010 campaign due to his performance in the leaders' debates would have brought new blood into the government.

\subsection{Brand Narrative}

During the decline stage a 'time for a change' narrative emerges. For example, Barack Obama tuned into this narrative in the 2008 US Presidential election arguing that he was the candidate of change and shift the direction of the United States after the presidency of George W. Bush. Likewise, during the last years of New Labour in government a 'time for a change' narrative emerged.

When a 'change' narrative begins, a political product's brand narrative becomes defensive. Also there is a tipping point when the 'time for a change' argument 
becomes accepted by the political market and so it becomes difficult to reverse the trend. The narrative of decline includes elements of Heppell symptoms of degeneration in governments. ${ }^{488}$ As outlined above the government handling of the economy was being highlighted by the GFC; Brown leadership abilities were being questioned; there were divisions within the party over the government's direction; there were implications of abuse of power with the expenses scandal; and political consumers were still being reminded of the government's past mistakes with the Chilcot Inquiry on Britain's role in Iraq taking place.

In this section focuses on the economic and weak leader narratives that emerged during New Labour's decline. Once there was momentum in the change narrative then there was little that the New Labour brand could do to overcome it. Gould's focus groups observed that they did give Brown credit for his handling of the GFC in its early days, but a couple of weeks of Brown showing valuable leadership skills was not enough to change people's long held opinions of Brown:

Brown was felt to have done well in the crisis, surpassing expectations: 'It sounds like he is doing a good job, and every other country is following his lead...'; 'I am amazed he's doing so well.' But [Brown] was not able to turn this success into enduring popularity. He had been a strong Chancellor but was not yet seen to be a Prime Minister. A lot of this was emotional: 'People see that he has done well but are not yet willing to allow this success to change their view of him. They are held back from doing so by feelings of resentment and a lack of empathy.' In a sense Gordon was unable to escape from his past, good or bad. ${ }^{489}$

Voters stuck to the basic position that 'Labour's time was up' and they 'are not going to allow a good week or two to change this perception, they are too

\footnotetext{
${ }^{488}$ Heppell (2008), p.580

${ }^{489}$ Gould (2011), p.509
} 
committed to it.' 490 The commitment to this position was probably created when Brown aborted the 2007 election, but it had been accumulating since the Iraq War. During the GFC blame was mainly aimed at the banks and the 'culture of excessive credit they had fostered.' 491 Gould's focus groups also showed that during the beginning of the GFC a perception emerged that 'Labour had contributed to this crisis, particularly in relation to debt and credit.' ${ }^{\prime} 92$

Part of the narrative of change is that the government, especially the primary brand agent has lost touch with ordinary voters. This was contrasted with the differences between Brown and Cameron in the lead up to the 2010 election. Cameron, who was pushing the change narrative, had a personal story was removed from that of political consumers. Rawnsley observed that Cameron is 'the son of a stockbroker...(and) lived a life remote from the experiences of most ordinary Briton.' ${ }^{493}$ But in contrast to Brown he was able to project the 'concerns of [the voters] daily struggles. Cameron responded to voters angst about raising fuel prices by talking about how much it costs to fill up the car. ${ }^{394}$ In contrast Brown's approach was to 'theorise on the workings of the international oil market.' 495

Once a narrative of change takes grip it is very hard to reverse it. Brown was not the right primary brand agent to shift New Labour away from this narrative. One observation about brand narratives during the product life-cycle is that at the beginning, New Labour did have more control of its narrative. In the decline stage the brand itself has a more difficult time shaping its own narrative. Once the symptoms of degeneration set in then it is hard to reverse or halt the narrative of decline.

\footnotetext{
${ }^{490}$ Gould (2011), p.509

${ }^{491}$ Gould (2011), p.509

${ }^{492}$ Gould (2011), p.509

${ }^{493}$ Rawnsley (2010), p.537

${ }^{494}$ Rawnsley (2010), p.537

${ }^{495}$ Rawnsley (2010), p.537
} 


\subsection{Brand agent}

Vincent's model, discussed in chapter two, illustrates the relationship between a primary brand agent and a brand. However, his model is a basic model and does not take into account the transition between one primary brand agent to another one. In the case of New Labour the dominance of the previous and much stronger primary brand agent, Tony Blair. New Labour in the decline cycle both the party and the leader was weak. In 2013 Blair even said 'Frankly, if I'd had a fourth election, I would have given Cameron a run for his money. I'm not saying I would have won, but it would have been tighter than it was.' ${ }^{\prime} 96$

Rawnsley questioned why New Labour did not change its primary brand agent in the lead up to the 2010 election given its recent history of changing itself to gain power. ${ }^{497}$ Rawnsley also observed:

In late 2009 the party's advertising agency had warned that 'Gordon is a walking magnetic field for everyone's negative feelings: their anger, anxiety, their broken washing machine or their kids' disappointing school results. They don't like the Tories. But given the choice, it seems they won't have Gordon.'498

During the 2010 election campaign the campaign was concerned about Brown's toxic image and reputation. Before the campaign Brown tried to connect with voters but these attempts never came across as genuine. Brown attempted to engage with the electorate by using YouTube to speak to young people, however these videos were ridiculed, even Brown's attempt to smile was mocked by the former Deputy Prime Minister, John Prescott. ${ }^{99}$ Brown was interviewed by celebrity journalist Piers Morgan on ITV's Life Stories. Morgan told Brown that he 'wanted to achieve a miracle. I'm going to try and make you sound Human.

\footnotetext{
${ }^{496}$ Press Association (2013) 'Tony Blair: I would have done better than Gordon Brown in 2010 election', The Guardian, Accessed 12 March 2014 <www.theguardian.com/politics/poll/2013/apr/05/tony-blair-gordonbrown-poll>

${ }^{497}$ Rawnsley (2011), p.692

${ }^{498}$ Rawnsley (2011), p.674

${ }^{499}$ Mark Wheeler (2013) Celebrity Politics, Polity, Cambridge, p.98
} 
Even vaguely human would be an improvement.'500 However, the format did reveal parts of Brown's personality, but he was out of his comfort zone.501

Brown's behaviour in the lead up to the 2010 election reinforced people's negative perceptions of him. For example, there were allegations that Brown terrified his staff. The Observer ran the headline 'Civil service chief warned Brown over abusive treatment of staff.' 502 Brown stated on Channel 4 news that 'I have never, never hit anybody in my life.' Peter Mandelson defended Brown on the Sunday Morning television shows by saying 'I don't think he so much bullies people as he is very demanding of people. ${ }^{503}$

One key moment where Brown's negative perceptions were highlighted during the 2010 election campaign was in Rochdale. Brown went on a walkabout where he met 65 year-old, life-long Labour supporter, Gillian Duffy. Duffy expressed to Brown her concerns about immigration, Brown answered her questions with respect and stated to her, in front of the cameras 'You're a very good woman, you've served your community all your life....It's been very good to meet you.' While Duffy was telling the cameras that Brown had won back her vote, Brown had left his microphone on and was recorded saying, 'That was a disaster. You should never have put me with that woman. Who's idea was that?...She was just a sort of bigoted woman. She said she used to be Labour. I mean, it's just ridiculous. ${ }^{504}$ This incident showed Brown being two-faced, nice in public but a bully in private.

Simply Brown was a primary brand agent representing a party that political consumers did not want in office. They were not keen on the opposition coming back into power either, but they were more willing to tolerate a David Cameron premiership over Brown's. New Labour was forcing the political market to accept a brand agent that had a toxic reputation. It was the first televised election

\footnotetext{
${ }^{500}$ Quoted in Rawnsley (2011), p.700

${ }^{501}$ Rawnsley (2011), p.700

${ }^{502}$ Rawnsley (2011), p.700

${ }^{503}$ Rawnsley (2011), p.701

${ }^{504}$ Rawnsley (2011), p.730
} 
debate in the UK; Brown thought that he could use the debates to overcome his 'toxic personal image'. ${ }^{505}$ But he also failed to shine in this forum as well with 'poorly timed jokes and his presentational shortcomings. ${ }^{506}$ In the decline cycle of the product life-cycle model, the primary brand agent is a liability. The primary brand agent also resigned as leader once the party moved from government to opposition.

\subsection{Summary}

Product

- New Labour's product shifted further away from a market-orientation and reverted to 'old' Labour style policies due to the GFC.

- There were questions about the legitimacy of Gordon Brown as Prime Minister.

- Greater divisions within the party and cabinet.

Position

- New Labour failed to defend its position as market-leader.

Brand narratives

- A 'time for a change' narrative became dominant.

Brand agent

- The Primary Brand Agent was unpopular and had a toxic reputation.

${ }^{505}$ Wheeler, p.100

${ }^{506}$ Wheeler, p.101 


\section{Conclusion}

The New Labour case study shows that the product life-cycle model does have application for political parties. Labour journeyed through the model's classic phases: New Labour's development through introduction, growth, maturity and decline phases were all seen in this study. Over the period of the cycle New Labour lost its hardly acquired market-orientation, as well as its strongest assets such as its leaders. Also, its perceived economic strength during its ascendant phases later became one of its chief weaknesses during its decline phase.

\section{Lessons from the case study about the Product Life-Cycle model}

The New Labour case study confirmed my hypothesis that 'product development and re-introduction' is a more appropriate term for the first cycle in the product life-cycle for a political party. That is, its development coincided with its introduction into the political market. Labour did experience a shift during the 'growth' cycle because it had entered office and was more accountable for its policies. However, the term 'growth' implies a further increase in support, which did not happen in the New Labour case study: 'consolidation' or 'market acceptance' could be more appropriate terms.

The case study also showed that the transition from the "product development and re-introduction' cycle to the 'growth' cycle and the 'maturity' cycle to the 'decline' cycle was triggered by very specific events, showing the influence of situations which come to represent a tipping point for movement from one phase of the cycle to another. In this study, the transition to the growth cycle was the result of winning the 1997 election while the transition to the decline cycle was the moment when Brown failed to call the autumn 2007 election. Yet, the transition from the growth cycle to the maturity cycle did not start after a defining moment. Rather, a more subtle process that began after September 2001 was viewed as the starting point for this cycle, but it could also be argued that the Iraq War was the legitimate starting point, or, perhaps, even Labour's re-election in 2001. 
The case study also confirms that a political product in the earlier stages of the product life-cycle model is more market-orientated and this market-orientation shifts as the product moves through the life-cycle. Duration in office seems to diminish the appeal of an incumbent government as it becomes subsumed by the demands of governing while beginning the process of becoming more remote and less sensitive to the electoral market.

\section{Lessons that the Product Life-Cycle Model about the New Labour case study}

The product life-cycle model also offers an opportunity for political scientists to look at the whole life of a political product. The model can also offer an opportunity to explain why political products fail and why they then get removed from office. For example the model does show that New Labour shifted into decline and was removed from office because it failed to rejuvenate itself properly and it was not offering a product and a leader that the political market wanted anymore. The market's expectations about New Labour changed and the party failed to meet these new expectations. Nor did the party adequately respond to changing perceptions about the New Labour product.

The same argument could be applied to the Australian Labor Government (20072013). When it disposed of Kevin Rudd as leader in 2010 it attempted to rejuvenate under Julia Gillard but, because she was not the leader that the political market wanted, that government experienced a very short maturity cycle and then went into decline after Gillard's government introduced a carbon tax after the 2010 election. This suggests that a long maturity period, with constant renewal and rejuvenation is what is needed if a government wishes to stay in power for a long time. The John Key-led National Government in New Zealand appear to be a better example of prolonging the maturity phase of the product life-cycle through constant and significant regeneration. However, as the New Labour case study shows, renewal and rejuvenation is not always possible due to conflicting personalities and constant involvement in world events. The case study shows that the following significant factors lead to decline: 
- A 'Time for a Change' narrative;

- Unpopular decisions already taken that the government cannot escape from;

- An unpopular leader.

The case study also suggests that the following factors may prevent, or at least stall, decline:

- A renewed electoral mandate;

- A new leader that is more responsive to the political market and one who is viewed by the electoral market as a legitimate successor, and;

- A real effort to stay connected or to reconnect with political consumers.

The case study also showed that the role of the opposition is also important: when the opposition party is unelectable then a political product like New Labour is a dominate market player. This situation changed once the opposition became more competitive. At that point, the market leader's internal contradictions and other weaknesses became more exposed, making them more vulnerable to change narratives.

\section{Further areas of research}

During my research, I found a lot of marketing literature that addresses how to revive a dying brand and rejuvenate it. This material could be used in future research into how to rejuvenate a political brand as the current literature is still limited on this aspect of the product life-cycle model.

An individual politician's career could also go through the product life-cycle model on their own according. While Blair's career followed Labour's progression through the model, Gordon Brown, viewed as a product, in his own right, became leader of the party when he was in his own maturity cycle, so too late to arrest the decline in the overarching New Labour product. Another area of research 
could focus on this relationship between the life-cycle of the party verses the lifecycle of the politician. For example in New Zealand when Helen Clark's government entered office in 1999 and when it was in its own growth cycle, Clark herself was a politician in the maturity cycle as she had experience in the previous Labour government and had managed to rejuvenate her own personal brand. As revealed by the case study, during New Labour's decline or maturity, a primary brand agent that was going through their own personal 'introduction' or 'growth' phase in the political market, rather than Brown, might conceivably have been enough to rejuvenate the party.

The product life-cycle is considered, in summary, a very good lens in which to chart the progress and then decline of a political party as it positions itself for government, as it achieves electoral success, as it then attempts to maintain its position as the market leader, and then as it finally collapses under the weight of changed perceptions and failures to continually respond to changed market conditions. Complementing other, more traditional methods of analysis, the product life-cycle model and the political marketing perspective shines an interesting and informative additional prism onto the problems of political parties seeking and holding onto power. 


\section{Bibliography}

\section{Articles}

- Burch, Martin and Ian Holliday (2004), 'The Blair Government and the Core Executive' Government and Opposition, vol.39:1 January 2004, pp.1-21

- Doig, Alan (2005), '45 Minutes of Infamy? Hutton, Blair and the Invasion of Iraq' Parliamentary Affairs vol.58:1, pp.109-123

- Doig, Alan (2005), 'Sleaze and Trust: Labour Trades Mistrust for Sleaze' Parliamentary Affairs, vol.58:2, pp.394-407

- Doig, Alan and Mark Pythian (2005), 'The Hutton Inquiry: Origins and Issues' Parliamentary Affairs vol.58:1, pp.104-108

- Fielding, Steven (2010), 'Labour's Campaign: Things Can Only Get...Worse?, Parliamentary Affairs, vol.63:4, pp.653-666

- Glees, Anthony (2005), 'Evidence-Based Policy or Policy-Based Evidence? Hutton and the Government's Use of Secret Intelligence' Parliamentary Affairs, vol.58:1, pp.138-155

- Grey, John (2004), 'Blair's Project in Retrospect,' International Affairs vol.80:1, pp.39-48

- Harris, Phil (2001), 'Commentary: Machiavelli, Political Marketing and Reinventing Government' European Journal or Marketing, vol.35 9/10 pp.1136- 1154

- Harrop, Martin (1990), 'Political Marketing' Parliamentary Affairs,' vol.43:3, pp.277-291

- Heffernan, Richard (2003), 'Prime ministerial predominance? Core executive politics in the UK,'British Journal of Politics and International Relations, vol. 5:3, pp.347-372

- Henneberg, Stephen C. (2004), 'The View of an Advocatus Dei: Political Marketing and its Critics,' Journal of Public Affairs, vol.4:3, pp.225-243

- Hennessy, Peter (2005), 'Rulers and Servants of the State: The Blair Style of Government 1997-2004' Parliamentary Affairs vol.58:1, pp.6-16

- Humphreys, James (2005), 'The Iraq Dossier and the Meaning of Spin’ Parliamentary Affairs vol.58:1, pp.156-170 
- Ingle, Stephen (2004), 'Politics: The Year the War Was Spun,' Parliamentary Affairs vol.57:2, pp.237-252

- Ingram, Peter and Jennifer Lees-Marshment (2002), 'The Anglicisation of Political Marketing: How Blair 'Out-Marketed' Clinton,' Journal of Public Affairs, vol.2:2, pp.44-56

- Katz, Richard S and Peter Mair (1995), 'Changing Models of Party Organization and Party Democracy: The Emergence of the Cartel Party,' Political Parties, vol.1:1, pp.5-28

- Kavanagh, Dennis (1996), 'Speaking Truth to Power? Pollsters as Campaign Advisers,' European Journal of Marketing, vol.3o n.10/11, pp.112-121

- Kennedy, Simon and Jonathan Joseph (2001) 'The Erosion of Party Politics in Britain,' New Political Science, vol.23:1, pp.267-283

- Lees-Marshment, Jennifer (2001b), 'The Marriage of Politics and Marketing,' Political Studies, vol.49:4, pp.692-713

- Lees-Marshement (2001c), 'The Product, Sales and Market-Oriented Party: How Labour Learnt to Market the Product, Not Just the Presentation,' European Journal of Marketing, vol.35 n.9/10, pp.1074-1084

- Lock, Andrew and Phil Harris (1996), 'Political Marketing - Vive la Difference!,' European Journal of Marketing, vol.30 10/11, pp.21-31

- Michael Lee, John (2001), 'Interpreting the 'Rebranding of Britain,' The Round Table, vol.362, pp.679-689

- Molony. Kevin (2001), 'The Rise and Fall of Spin: Changes of Fashion in the Presentation of UK Politics,' Journal of Public Affairs, vol.1:2, pp.124-135

- Mortimore, Roger (2003), 'Why Politics Needs Marketing' International Journal of Nonprofit and Voluntary Sector Marketing, vol.8:2, pp.107-121

- Needham, Catherine, (2005), 'Brand Leaders: Clinton, Blair and the Limitations of the Permanent Campaign,' Political Studies, vol.53, pp.343361

- Norris, Pippa (1997), 'Anatomy of a Labour Landslide', Parliamentary Affairs, vol.50:4 pp.509-532

- Norton, Philip (2003), 'Governing Alone,' Parliamentary Affairs, vol.56:4, pp. $543-559$ 
- O'Shaughnessy, Nicholas (2001), 'The Marketing of Political Marketing,' European Journal of Marketing, vol.35 9/10, pp.1047-1057

- O'Shaughnessy, Nicholas (2003), 'The Symbolic State: A British Experience,' Journal of Public Affairs, vol3:4, pp.297-312

- Putnam, Robert D. (1996), 'The Strange Disappearance of Civic America' The American Prospect vol.7:24 < prospect.org/printfriendly/print/V7/24/putnamr.html>

- Rajagopal and Sanchez, Romulo (2004), 'Conceptual Analysis of Brand Architecture and Relationships within Product categories,' Journal of Brand Management, vol.11:3, pp.233-247

- Ravald, Annika and Christian Grönroos (1996), 'The Value Concept and Relationship Marketing' European Journal of Marketing, vol.30:2, p.19-30

- Sackman, Adrian I. (1996) 'The Learning Curve Towards New Labour: Neil Kinnock's Corporate Party 1983-92,' European Journal of Marketing, vol.30:10/11, pp.147-158

- Scammell, Margaret (1999), 'Political Marketing: Lessons for Political Science' Political Studies, XLVII, pp.718-739

- Scammell, Margaret (2000), 'The Internet and Civic Engagement: The Age of the Citizen-Consumer,' Political Communucation, vol.17, p.351-355

- Scammell, Margaret (2007), 'Political Brands and Consumer Citizens: The Rebranding of Tony Blair, The Annals of the American Academy of Political and Social Science, vol.611, pp.176-192

- Seyd, Patrick (1999), 'New Parties/New Politics?: A Case Study of the British Labour Party,' Party Politics, vol.5:3, pp.383-405

- Seyd, Patrick and Paul Whiteley (2004), 'British Party Members: An Overview' Party Politics, vol.10:4, pp.355-366

- Shaw, Eric (2002), 'New Labour in Britain: New Democratic Centralism,' West European Politics, vol.25:3, pp.147-179

- Sparrow, Nick and John Turner (2001) 'The Permanent Campaign: The integration of market research techniques in developing strategies in a more uncertain political climate,' European Journal of Marketing vol.35 pp.9841002 
- Stanyer, James (2003)' 'Politics and the Media: A Breakdown in Relations for New Labour,' Parliamentary Affairs, vol.56, pp.309-321

- Stanyer, James (2004), 'Politics and the Media: A Crisis of Trust,' Parliamentary Affairs, vol.57:2, pp.420-434

- Street, John (2004), 'Celebrity Polticians: Popular Culture and Political Representation,' The British Journal of Politics and International Relations, vol.6:4, pp.435-452

- Van Ham, Peter (2002) 'Branding Territory: Inside the Wonderful Worlds of PR and IR Theory,' Millennium, vol.31:2, pp.249-269

- Webb, Paul, and Justin Fisher (2003), 'Professionalism and the Millbank Tendency: The Political Sociology of New Labour's Employees,' Politics, vol.23:1, pp.10-20

- Wheatcroft, Geoffrey (2004), 'The Tragedy of Tony Blair,' Atlantic Monthly, pp.56-70

- Wring, Dominic (2005), 'Politics and the Media: The Hutton Inquiry, the Public Relations State, and Crisis at the BBC,' Parliamentary Affairs, vol.58:2, pp.380-393

\section{Books}

- Bartle, John; Roger Mortimore, Simon Atkinson (eds.) (2002), Political Communications: The General Election of 2001, Frank Cass, London

- Blair, Tony (2010), A Journey, Arrow Books, London

- Boorstin, Daniel (1987) The Image: A Guide to Pseudo-Events in America, Vintage Books, New York

- Butler, David and Dennis Kavanagh (1980), The British General Election of 1979, Macmillan, London

- Butler, David and Dennish Kavanagh (1984), The British General Election of 1983, Macmillan, London

- Butler, David and Dennis Kavanagh (1992), The British General Election of 1992, MacMillan, London 
- Butler, David and Dennis Kavanagh (1997), The British General Election of 1997, MacMillan, London

- Butler, David and Dennis Kavanagh (2002), The British General Election of 2001, Palgrave, London

- Coates, David and Peter Lawler (eds.) (2000), New Labour in Power Manchester University Press, Manchester

- Corner, John and Dick Pels (eds) (2003), Media and the Restyling of Politics: Consumerism, Celebrity and Cynicism, Sage, London

- Crewe, Ivor, Brian Gosschalk and John Bartle (eds) (1998), Political Communication: Why Labour Won the General Election of 1997, Frank Cass, London

- Gardner, Howard (1995), Leading Minds: An Anatomy of Leadership, Basic Books, New York

- Gould, Philip (1998a), The Unfinished Revolution: How the Modernisers Saved the Labour Party, Little, Brown and Company, London

- Gould, Philip (2011), The Unfinished Revolution: How New Labour Changed British Politics For Ever, Abacus, London

- Hennessy, Peter (2000), The Prime Minister: The Office and its Holders Since 1945, Allen Lane, London

- Hyman, Peter (2005), 1 Out of 10: From Downing Street Vision to Classroom Reality, Vintage London

- Jones, Nicholas (1997), Campaign 1997: How the General Election was Won and Lost, Indigo, London

- Jones, Nicholas (2001), The Control Freaks: How New Labour Gets Its Own Way,Politico's London

- Kampfner, John (2004), Blair's Wars, Free Press, London

- Kavanagh, Dennis and Anthony Seldon (2000), The Powers Behind the Prime Minister: The Hidden Influence of Number Ten, HarperCollins, London

- King, Anthony (ed.) (1998), New Labour Triumphs: Britain at the Polls, Chatham House Publishers, London

- Klein, Naomi (2001), No Logo, Flamingo, London 
- Kotler, Philip and Gary Armstrong (2012) Principles of Marketing (14th Edition) Peason

- Lees-Marshment, Jennifer (2001a), Political Marketing and British Political Parties: The Party's Just Begun, Manchester University Press, Manchester

- Lees-Marshment, Jennifer (2004), The Political Marketing Revolution: Transforming the Government of the UK, Manchster University Press, Manchester

- Lees-Marshment, Jennifer (2009), Political Marketing, Principles and Applications, Routledge, Oxon

- Ludlam, Steve and Marin J. Smith (eds) (2004), Governing as New Labour: Policy and Politics Under Blair, Palgrave MacMillian, London

- Machiavelli, Niccolò (2003), The Prince, George Bull (Translator), Penguin Books, London

- Mandelson, Peter (2011), The Third Man, Harper Press, London

- Miller, Raymond (2005), Party Politics in New Zealand Oxford University Press, Oxford

- Moor, Liz (2007), The Rise of Brands, Berg, Oxford

- O'Farrell, John (1998), Things Can Only Get Better: Eighteen Miserable Years in the Life of a Labour Supporter 1979-1997, Doubleday, London

- O'Shaughnessy, Nicholas J. (ed) Stephen Henneberg (associate ed.) (2002), The Idea of Political Marketing, Praeger, Westport, CT

- Panebianco, Angelo (1988), Political Parties: Organization and Power, Cambridge University Press, Cambridge

- Powell, Jonathan (2010), The New Machiavelli: How to Wield Power in the Modern World, Vintage Books, London

- Putnam, Robert D., (2000), Bowling Alone: The Collapse and Revival of American Community, Simon \& Schuster, New York

- Seyd, Patrick and Paul Whiteley (2002), New Labour's Grassroots: The Transformation of the Labour Party Membership, Palgrave MacMillian, London

- Seldon, Anthony (ed.) (2002), The Blair Effect, Little Brown, London

- Seldon, Anthony (2004), Blair, Simon \& Schuster, London 
- Seldon, Anthony, and Guy Lodge (2011), Brown at 10, Biteback Publishing, London

- Sheppard, Simon (1999), Broken Circle: The Decline and Fall of the Fourth Labour Government, Publishing Solutions Ltd, Wellington

- Stephens, Philip (2004), Tony Blair: The Price of Leadership, Poltico's, London

- Stothard, Peter (2003), 30 Days: A Month at the Heart of Blair's War, HarperCollins, London

- Rawnsley, Andrew (2001), Servants of the People:The Inside Story of New Labour, Penguin, London

- Rawnsley, Andrew (2010), The End of the Party: The Rise and Fall of New Labour, Penguin, London

- Rojek, Chris (2001), Celebrity, Reaktion Books, London

- Rose, Richard (2002), The Prime Minister in a Shrinking World, Polity Press, London

- Russell, Meg (2005), Building New Labour: The Politics of Party

Organisation, Palgrave Macmillan, London

- Turner, Graeme (2004), Understanding Celebrity, Sage, London

- Wheeler, Mark (2013), Celebrity Politics, Polity, Cambridge

- Vincent, Laurence (2002), Legendary Brands: Unleashing the Power of Storytelling to Create a Winning Marketing Strategy, Dearborn, Chicago

\section{Chapters in Books}

- Barrie Axford and Richard Huggins (2002) 'Political Marketing and the Aestheticisation of Politics: Modern Politics and Postmodern Trends,' in Nicholas O'Shaughnessy and Stephan Henneberg (eds), The Idea of Political Marketing, Praeger, Westport, CT. pp.187-207

- Coates, David (2000), 'The Character of New Labour' in David Coates and Peter Lawler, (eds.) New Labour in Power, Manchester University Press, Manchester, pp.1-15 
- Collins, Neil and Patrick Butler (2002), 'Considerations on Market Analysis for Political Parties,' in Nicholas O'Shaughnessy and Stephan Henneberg (eds.), The Idea of Political Marketing, Praeger, Westport, CT.

- Crewe, Ivor (1981), 'Why the Conservatives Won,', in Howard R. Penniman, (ed) Britain at the Polls, American Enterprise Institute, Washington pp.263305

- Dalton, Richard J and Martin P. Wattenberg (2000) 'Unthinkable Democracy: Political Change in Advance Industrial Democracies,' in Richard J. Dalton and Martin P. Wattenberg (eds), Parties Without Partisans: Political Change in Advance Industrial Democracies, Oxford University Press, Oxford, pp.2-16

- Driver, Steven and Luke Martell (2001), 'Blair and 'Britishness' in David Morley, and Kevin Robins (ed), British Cultural Studies: Geography, Nationality, and Identity, Oxford University Press, Oxford, pp.461-472

- Farrell, David (1996) 'Campaign Strategies and Tactics,' in Lawrence LeDuc, Richard G. Niemi, Pippa Norris, (eds), Comparing Democracies: Elections and Voting in Global Perspective, Sage, Thousand Oaks, pp.160-183

- Gould, Philip (1998), 'Why Labour Won,' in Ivor Crewe, Brian Gosschalk and John Bartle (eds), Political Communication: Why Labour Won the General Election of 1997, Frank Cass, London

- Gould, Philip (2002), 'Labour Party Strategy' in John Bartle, Simon Atkinson, Roger Mortimore (eds), Political Communications: the General Election of 2001, Frank Cass, London, pp.57-68

- Henneberg, Stephan C.M. and Stegan Eghbalian (2002), 'Kirchheimer's Catch-all Party: A Reinterpretation in Marketing Terms,' in Nicholas O'Shaughnessy and Stephan Henneberg (eds) The Idea of Political Marketing, Praeger, Westport, CT,. pp.67-91

- King, Anthony (1981), 'Politics, Economics, and Trade Unions,' in Howard R. Penniman, (ed), Britain at the Polls, American Enterprise Institute, Washington pp.30-94 
- Kirchheimer, Otto (1966), 'The Transformation of the Western European Party Systems,' in J LaPalombara \& M. Weiner (eds), Political Parties and Political Development, Princeton University Press, New Jersey

- Leonard, Dick (1981), 'The Labour Campaign,' in Howard R. Penniman (ed), Britain at the Polls, American Enterprise Institute, Washington, pp.95-116

- Livingston, William S. (1981), 'The Conservative Campaign,' in Howard R. Penniman (ed), Britain at the Polls, American Enterprise Institute, Washington, pp.117-158

- Shaw, Eric (2004), 'The Control Freaks? New Labour and the Party,' in Steve Ludlam and Martin J. Smith (eds), Governing as New Labour: Policy and Politics under Blair, Palgrave Macmillian, London, pp.52-69

\section{Speeches and Conference Papers}

- Blair, Tony (2005) 'Spring Conference Speech,' The Guardian Accessed 28 March 2014 <www.theguardian.com/politics/2005/feb/14/labour.speeches>

- Cameron, David (2006),'Modern Conservatism. Speech to Demos' Conservative Party Website, Accessed 25 June 2006 , $<$ www.conservatives.com/tile.do?def=news.story.page\&obj_id=127560\&speec hes $=1>$

- Langmaid, Roy; Charles Trevail and Ben Heyman (2006) 'Reconnecting the Prime Minister' Research 2006 Conference Paper, Accessed 15 March 2014, <www.promisecorp.com/documents/Reconnecting_the_Prime_Minister.pdf $>$

- Thompson, Stuart, (1999) 'The Changing Structure of the Labour Party: A Leader-Centred Party?', Accessed November 2005 $<$ www.psa.ac.uk/cps/1999/thomson.pdf $>$ Political Studies Association Conference, Nottingham

\section{Media and Internet Sources}

- '1979 Conservative Party General Election Manifesto'(1979), Accessed 19 July 2005, <www.conservative-party.net/manifestos/1979/1979-conservativemanifesto.shtml $>$ 
- Best Party on Key Issues: Healthcare' (2013), Ipsos MORI website, Accessed 16 February 2014, <www.ipsos-

mori.com/researchpublications/researcharchive/

poll.aspx?oItemID=23\&view=wide>

- 'Bombing Iraq' (2003) ICM Research website' Accessed 25 November 2005, <www.icmresearch1.co.uk/reviews/vote-intention-reports/bombing-iraq.asp>

- 'Cash-for-Honours timeline'(2007) The Guardian, Accessed March 142014 <www.theguardian.com/politics/2007/oct/11/partyfunding.uk>

- Epstein, Jason (2004) 'Mystery in the Heartland,' The New York Review of Books Glover, Glover,

- 'Ipsos MORI March Political Monitor' (2010), Ipsos Mori Website, Accessed 3 April 2014, <WWW.ipsosmori.com/Assets/Docs/Polls/Mar10\%20Political\%20MonitorTopline_BPOK I.pdf $>$

- 'Ipsos MORI Political and Social Trends', Ipsos Mori Website, Accessed 16 February 2013, <www.ipsosmori.com/researchspecialisms/socialresearch/specareas/politics/trends.aspx>

- 'Ipsos MORI Political Monitor Satisfaction Ratings 1988-1997' (1997), Ipsos Mori Website, Accessed 23 March 2013, www.ipsosmori.com/researchpublications/researcharchive/poll.aspx?oItemID=2438\&vie $\mathrm{w}=$ wide

- 'Labour's Changing Promises' The Guardian, Accessed 14 March 2014 <www.theguardian.com/politics/2000/jul/13/labour.labour1997to991>

- 'General Election 2001: Pre-Campaign Survey' (2001), Ipsos MORI website, Accessed 15 March 2014, <www.ipsosmori.com/researchpublications/researcharchive/1217/General-Election-2001PreCampaign-Survey.aspx>

- Guardian / ICM Polls: everyone since 1984' accessed 19 April 2013 <www.guardian.co.uk/news/datablog/2009/oct/21/icm-poll-data-labourconservatives>

- $\quad$ 'Labour Party Manifesto, General Election 1997,' Accessed 1 December 2005 <www.psr.keele.ac.uk/area/uk/man/lab97.htm>

- 'Local Elections, Kosovo and the Tory Leadership,' (1999) Ipsos MORI Website, Accessed 16 March 2013 <www.ipsosmori.com/researchpublications/researcharchive/1861/Local-Elections-Kosovoand-the-Tory-Leadership.aspx> 
- Miliband, David (2008) 'Against All Odds, We Still Can Win, On a Platform for Change' The Guardian,Accessed 17 April 2014 <www.theguardian.com/commentisfree/2008/jul/29/davidmiliband.labour>

- “Million’ march against Iraq War", (2003), BBC News, Accessed 23 February 2014, <news.bbc.co.uk/2/hi/2765041.stm>

- McGuinness, Feargal (2012) 'Membership of UK political parties,' House of Commons Library, Accessed 7 May $2014<w w w . p a r l i a m e n t . u k / b r i e f i n g-$ papers/SN05125.pdfs

- 'Political Monitor - Satisfaction Ratings 1988-1997' (1997) Ipsos MORI Website, Accessed 16 February 2013 www.ipsosmori.com/researchpublications/researcharchive/poll.aspx?oItemID=2438\&vie $\mathrm{w}=$ wide

- 'Political Monitor: Satisfaction Ratings 1997-Present' (2014), Ipsos MORI website, Accessed 3 April $2014<\mathrm{www} . \mathrm{wpsos}^{-}$ mori.com/researchpublications/researcharchive/poll.aspx?oItemID $=88 \&$ view $=$ wide>

- Press Association (2013) 'Tony Blair: I would have done better than Gordon Brown in 2010 election', The Guardian, Accessed 12 March 2014 $<$ www.theguardian.com/politics/poll/2013/apr/05/tony-blair-gordon-brownpoll>

- Rawnsley, Andrew (2013), 'The Conservatives are plotting and talking themselves to death, Guardian Website, Accessed 13 February 2014, $<$ www.guardian.co.uk/commentisfree/2013/mar/17/tories-not-in-hell-but-canput-themselves-there>

- Woodward, Will (2007), 'Spin and Scandal: How New Labour made the news' The Guardian, Accessed 24 Jun 2013, $<$ www.theguardian.com/media/2007/jun/13/politicsandthemedia.pressandpub lishing> 